\title{
Pekka Borchers
}

\section{"Issues like this have an impact" The Need-Adapted Treatment of Psychosis and the Psychiatrist's Inner Dialogue}

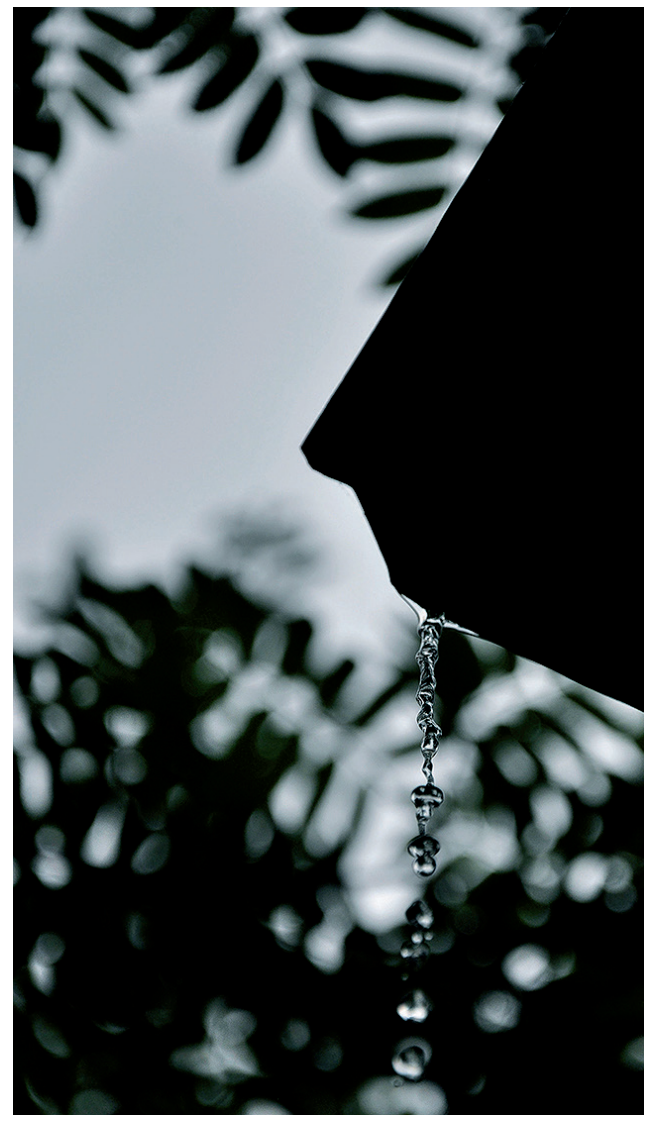




\title{
Pekka Borchers
}

\section{"Issues like this have an impact"}

\author{
The Need-Adapted Treatment of Psychosis \\ and the Psychiatrist's Inner Dialogue
}

Esitetään Jyväskylän yliopiston yhteiskuntatieteellisen tiedekunnan suostumuksella julkisesti tarkastettavaksi yliopiston vanhassa juhlasalissa S212

lokakuun 25. päivänä 2014 kello 12.

Academic dissertation to be publicly discussed, by permission of the Faculty of Social Sciences of the University of Jyväskylä,

in building Seminarium, auditorium S212, on October 25, 2014 at 12 o'clock noon.

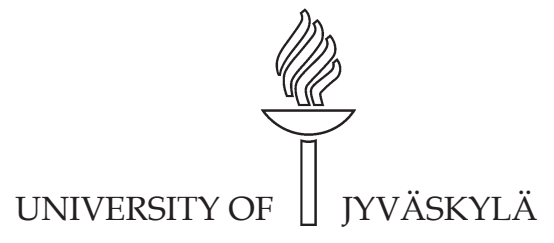

JYVÄSKYLÄ 2014 
"Issues like this have an impact"

The Need-Adapted Treatment of Psychosis and the Psychiatrist's Inner Dialogue 


\section{Pekka Borchers}

\section{"Issues like this have an impact" \\ The Need-Adapted Treatment of Psychosis and the Psychiatrist's Inner Dialogue}

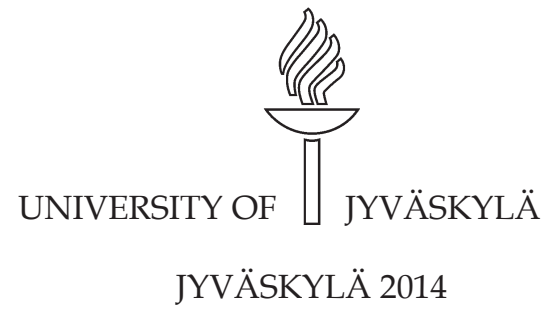




\section{Editors}

Timo Suutama

Department of Psychology, University of Jyväskylä

Pekka Olsbo, Ville Korkiakangas

Publishing Unit, University Library of Jyväskylä

Cover photo by Joonatan Borchers.

URN:ISBN:978-951-39-5861-9

ISBN 978-951-39-5861-9 (PDF)

ISBN 978-951-39-5860-2 (nid.)

ISSN 0075-4625

Copyright @ 2014, by University of Jyväskylä

Jyväskylä University Printing House, Jyväskylä 2014 


\author{
ABSTRACT \\ Borchers, Pekka \\ "Issues like this have an impact": the Need-Adapted Treatment of Psychosis \\ and the Psychiatrist's Inner Dialogue \\ Jyväskylä: University of Jyväskylä, 2014, 87 p. \\ (Jyväskylä Studies in Education, Psychology and Social Research \\ ISSN 0075-4625; 507) \\ ISBN 978-951-39-5860-2 (nid.) \\ ISBN 978-951-39-5861-9 (PDF)
}

This research aimed to describe the inner dialogues of psychiatrists in the context of the Need-Adapted treatment of psychosis. It strived to show that the experiences of professionals can have an impact on the treatments offered. In addition, the research aimed to clarify how the phenomenon of professionals' inner dialogues may be studied.

The data for the three studies of the research consisted of eight videotaped and transcribed stimulated recall interviews with psychiatrists, who recalled their inner dialogues, assisted by videos from co-research interviews. The dialogues took place in multi-agent discussions with patients, with the family members of patients, and with other professionals. The first study provided an overall picture of the research material, with a focus on psychiatrists' inner dialogues concerning their workmates. The second study focused on how the psychiatrists viewed their agency. The third study dealt with the impact of psychosis on the treatment, the psychiatrists, and other professionals. The first two studies used adaptations of dialogical-narrative analysis, while the third study used an adaptation of qualitative content analysis.

From the perspective of real-world clinical practice the studies suggested the following: (i) since psychiatrists interact with the clients and with other professionals, they respond as embodied individual human beings with possibly strong emotions; this suggests that the experiences and inner dialogues of the participants may be interdependent; (ii) clinician-clinician relationships can be of crucial importance in the treatment; (iii) especially in the inpatient setting, institutional forces can have an enormous impact on psychiatrists' agency by reducing professional creativity, and occasionally, by leading to a kind of agentless situation; (iv) psychiatrists seem to be more or less aware of the many harmful effects of (in particular) inpatient treatment; (v) the interview methods used in the research increased professionals' reflective opportunities, indicating that such interviews could be helpful in the dilemmas professionals encounter in practice.

Keywords: psychosis, Need-Adapted treatment, psychiatrists, inner dialogue, qualitative multiple case study 
Author's address

Supervisors

Reviewers

Opponent
Pekka Borchers

Department of Psychology

University of Jyväskylä

Jyväskylä, Finland

pekka.borchers@fimnet.fi

Professor Jaakko Seikkula

Department of Psychology

University of Jyväskylä

Jyväskylä, Finland

Doctor Klaus Lehtinen

Tampere University Hospital

Tampere, Finland

Professor Tom Arnkil

National Institute of Health and Welfare

Helsinki, Finland

Professor Raimo Puustinen

School of Medicine

University of Tampere

Tampere, Finland

Professor Bogdan de Barbaro

Department of Psychiatry

Jagiellonian University

Krakow, Poland

Professor Aarno Laitila

School of Educational Sciences and Psychology

University of Eastern Finland

Joensuu, Finland 


\section{TIIVISTELMÄ}

Borchers, Pekka

"Tällasetkin asiat vaikuttaa" - psykoosien tarpeen mukainen hoito ja psykiatrien sisäinen keskustelu.

Jyväskylä: Jyväskylän yliopisto, 2014, 87 s.

(Jyväskylä Studies in Education, Psychology and Social Research

ISSN 0075-4625; 507)

ISBN 978-951-39-5860-2 (nid.)

ISBN 978-951-39-5861-9 (PDF)

Tämän tutkimuksen tavoite oli kuvata psykiatrien sisäistä keskustelua psykoosien tarpeenmukaisen hoitomallin kontekstissa. Se pyrki osoittamaan, että ammattilaisten kokemuksilla voi olla vaikutusta tarjottuun hoitoon, ja selvittämään, miten ammattilaisten sisäistä keskustelua voidaan tutkia.

Kolmen osatutkimuksen aineisto koostui kahdeksasta videolle tallennetusta ja transkriptoidusta stimulated recall -haastattelusta, joissa psykiatrit yhteisen tutkimisen haastattelun kuvanauhan avulla palauttivat mieleensä sisäistä keskusteluaan. Yhteisen tutkimisen haastattelu oli ryhmäkeskustelu, jossa oli lääkärien ohella läsnä potilas, hänen perheenjäseniään sekä muita ammattilaisia. Ensimmäisessä osatutkimuksessa kuvattiin tutkimusaineistoa kokonaisuudessaan ja keskityttiin psykiatrien työtovereita koskevaan sisäiseen keskusteluun. Toisessa osatutkimuksessa paneuduttiin psykiatrien kokemukseen toimijuudestaan. Kolmas osatutkimus käsitteli psykoosin vaikutusta hoitoon, psykiatreihin ja muihin ammattilaisiin. Kahdessa ensimmäisessä osatutkimuksessa sovellettiin dialogis-narratiivista analyysimenetelmää ja kolmannessa laadullista sisällön analyysia.

Tosielämän kliinisen toiminnan kannalta tutkimuksien keskeiset löydökset olivat seuraavat: (i) vuorovaikutuksessa asiakkaiden ja toisten ammattilaisten kanssa psykiatrit vastaavat toisten vuorovaikutukseen kehollisina inhimillisinä yksilöinä, joilla on vahvojakin tunteita, mikä viittaa siihen, että eri osapuolten kokemukset ja sisäiset dialogit voivat olla keskenään riippuvaisia; (ii) työntekijöiden keskinäiset suhteet saattavat olla tärkeä hoitoon vaikuttava tekijä; (iii) erityisesti sairaalahoidossa institutionaaliset ilmiöt voivat vaikuttaa oleellisesti psykiatrien toimijuuteen vähentämällä heidän luovuuttaan ja johtaa ajoittain tilanteisiin, joissa yksittäisten työntekijöiden inhimillinen toimijuus näyttää kokonaan katoavan; (iv) psykiatrit näyttävät olevan enemmän tai vähemmän tietoisia erityisesti sairaalahoitoihin liittyvistä monista haitoista; (v) tutkimuksessa käytetyt haastattelumenetelmät lisäsivät ammattilaisten mahdollisuuksia itsereflektioon, ja ne voivat olla käyttökelpoisia apuvälineitä käytännön työn haasteissa.

Avainsanat: psykoosi, tarpeenmukainen hoito, psykiatrit, sisäinen keskustelu, laadullinen monitapaustutkimus 


\section{ACKNOWLEDGEMENTS}

Although this thesis has been in many ways a personal project demanding seemingly endless lonely hours on the computer, it would not have been possible without the support of very many people.

First of all, I am grateful to have had Professor Jaakko Seikkula as my principal supervisor. I can imagine no one else to whom I could have turned with my obscure and somewhat unconventional ideas for studying the challenges arising in psychiatrists' treatment of psychosis. Jaakko, I have learned so much from you. Thank you for your patience - and also for not giving (straight) answers! Two other members of my multiprofessional supervisory group have been crucial on several occasions. Doctor Klaus Lehtinen's unwavering integrative attitude, within the overall Need Adapted approach, has always impressed me. His detailed readings of my versions, practical comments, and suggestions - concerning also computer programs - have made the job easier for me. Professor Tom Arnkil had a major role in the initial design of the interview protocol and in the third article. I admire his heartfelt and cheerful wisdom and appreciate his practical advice. Thank you, Klaus and Tom.

I am sincerely grateful to the reviewers of my thesis. Professor Raimo Puustinen's positive feedback and detailed remarks helped me to improve the final version of this work, and I will always remember Professor Bogdan de Barbaro's respect for the thesis, something that has given me strength in the home stretch of this marathon.

There are several persons from the Department of Psychology at the University of Jyväskylä who have contributed to this project. Along with Jaakko Seikkula I want to mention first of all Professor Jarl Wahlström, who has been a kind of an unofficial fourth supervisor. In our doctoral workshops and seminars Professors Seikkula and Wahlström have complemented each other. Jalle thank you for giving me answers - including some straight ones! Aarno Laitila and Juha Holma have been important participants in the inspiring workshops of the psychotherapy doctoral education program. Without the help of Raija Mehto, I - as well as many others in our group of doctoral students - would not have finished the studies. I myself have been enjoyed reading the fluent English of the thesis, which I owe mainly to Donald Adamson. Thank you also, Timo Suutama, for your care in correcting the text.

I am thankful for the financial support of the University of Jyväskylä, the Finnish Psychiatric Association, and the Finnish Family Therapy Association.

The workshops, the supervision sessions, and the annual psychotherapy research congress in Jyväskylä have been inspiring and extremely important for a lonely researcher like myself. I am grateful for the comments of my fellow students and other participants on these occasions. I especially want to mention Eija-Liisa Rautiainen, Ilpo Kuhman, and Tapio Ikonen. In addition, I want to thank Jarmo Kontunen for his assistance in using the Atlas.ti computer program.

I have encountered the challenges of the psychosis phenomenon in the company of quite a large number of people. Every single patient or client who 
has experienced psychosis - whether personally or in a family member - has taught me something. It is really sad that I must stick to phrases such as "patient" or "client" instead of offering my gratitude by naming some of the most important of them. Out of the many professionals I have worked with, I feel obliged to name my former coworkers in Jorvi Hospital outpatient clinic, or "psyppi" as we used to call it. In addition to trying seriously and enthusiastically to help our patients and their families, we had a thoroughly enjoyable time in each other's company. I would also like to extend my deepest gratitude to those many colleagues in Finnish psychiatry with family therapeutic training and with a passion also for treating psychosis psychotherapeutically. I myself have had the possibility to meet Emeritus Professor Yrjö Alanen only on a couple of occasions; he is indeed the hero of two generations of psychotherapeutically oriented Finnish psychiatrists. In addition to Klaus Lehtinen I also want to mention Heimo Salminen, Katriina Kuusi, Jukka Aaltonen, Viljo Räkköläinen and Birgitta Alakare.

Outside the academic and professional world I thank acquaintances, friends, and relatives who have shown interest by asking questions about this peculiar research - interactions of this kind do indeed have an impact.

I have deliberately left the most important persons to the end. I offer my heartfelt gratitude to all the interviewees, the patients, their family members and the professionals, for making this extremely interesting journey possible. To you I dedicate the verses at the beginning and end of the thesis.

Finally I have the possibility the express my gratitude to my loved ones. In addition to Jaakko there is one person without whom this thesis would not even have begun. My wife Paula has been willing to take on so many responsibilities in our daily life to let me concentrate on the research, and she has been there in the moments of despair, exhaustion, and frustration. Futhermore as a psychiatric nurse and a family therapist herself, she has been genuinely interested in all the steps of my project. Paula, you have given me more than I could ever have deserved. This research process has been fascinating and inspiring, and it has changed me as a person - and yes, I am proud of what I have done. Nonetheless, nothing in my life has been so full of meaning and pride as the possibility with Paula to be parents of our three wonderful children - something that perhaps only the experience of being grandparents, some day, could equal. Josefina, Joonatan (thank you also for the photo) and Aleksandra, there are really no words to describe how grateful I am just for your existence and for the opportunity to try to learn unconditional love.

Helsinki, August 2014

Pekka Borchers 


\section{LIST OF ORIGINAL PUBLICATIONS}

I Borchers, P., Seikkula, J., \& Lehtinen, K. (2013). Psychiatrists' inner dialogues concerning workmates during Need Adapted treatment of psychosis. Psychosis, 5, 60-70.

II Borchers, P., Seikkula, J., \& Lehtinen, K. (2014). Psychosis, Need Adapted treatment, and psychiatrists' agency. Psychosis, 6, 27-37.

III Borchers, P., Seikkula, J., \& Arnkil, T. E. (2014). The Need Adapted Approach in psychosis: The impact of psychosis on the treatment, and professionals. Ethical Human Psychology and Psychiatry, 16, 5-19.

Taking into account the instructions and comments made by co-authors, the author of the thesis collected the data, conducted the analysis, and wrote the reports of the three publications, independently. 


\title{
CONTENTS
}

\author{
ABSTRACT \\ TIIVISTELMÄ \\ ACKNOWLEDGEMENTS \\ LIST OF ORIGINAL PUBLICATIONS \\ CONTENTS
}

1 INTRODUCTION

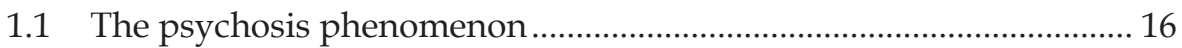

1.1.1 The conceptual background ..................................................... 16

1.1.2 The recovery approach ............................................................ 19

1.2 Experiences of psychosis, treatment, and recovery ............................ 19

1.2.1 The experiences of service users ................................................ 20

1.2.2 The experiences of family members ....................................... 21

1.2.3 The experiences of professionals............................................. 23

1.2.4 Social and institutional perspectives ........................................ 24

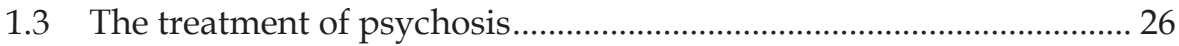

1.3.1 The Need-Adapted Approach (NAA) ....................................... 27

1.3.2 Recovery-oriented services ........................................................... 30

1.3.3 A critical review of the Finnish Current Care Guidelines on

Schizophrenia.......................................................................... 31

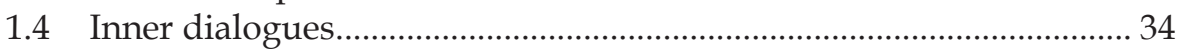

1.4.1 The professional's inner dialogue.............................................. 35

1.4.2 Therapeutic relationships in a multi-agent treatment setting .. 37

1.4.3 Professional agency.................................................................. 40

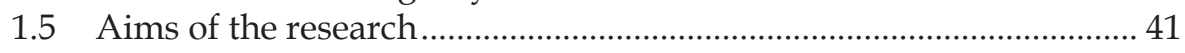

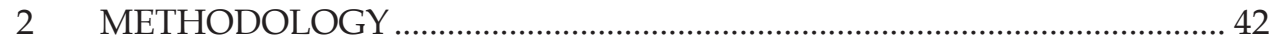

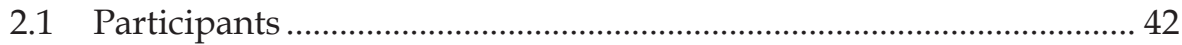

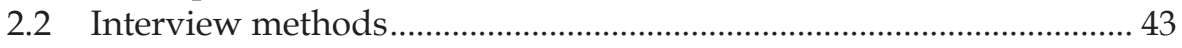

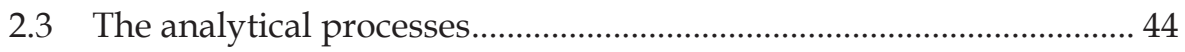

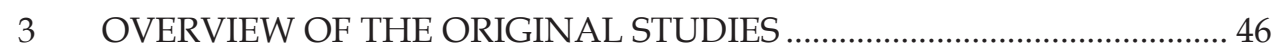

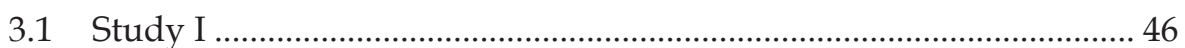

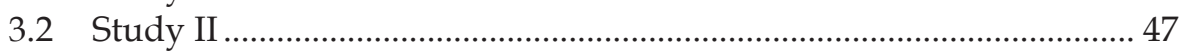

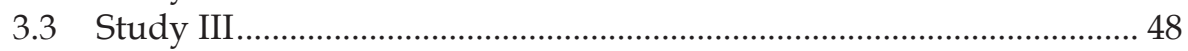

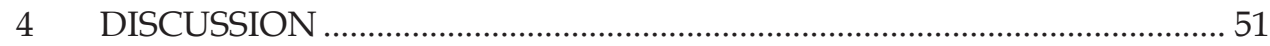

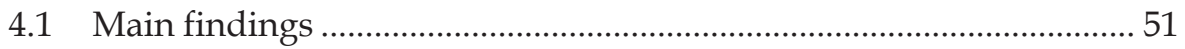

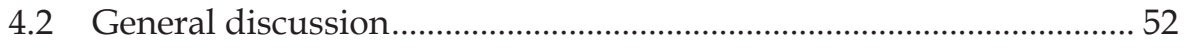

4.3 Clinical implications: how to better adapt the treatment

of psychosis to the needs of the clients ............................................... 56

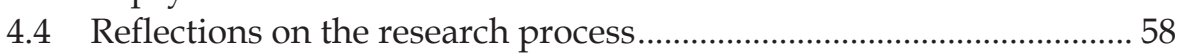


4.4.1 Strengths and limitations of the research .................................... 58

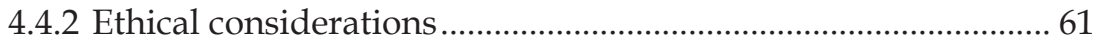

4.4.3 Personal reflections: confirmations and surprises........................ 63

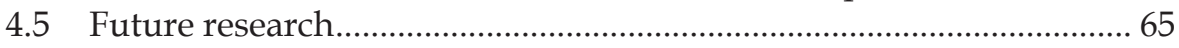

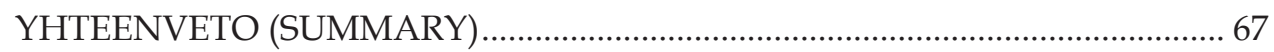

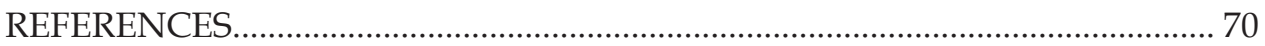




\section{INTRODUCTION}

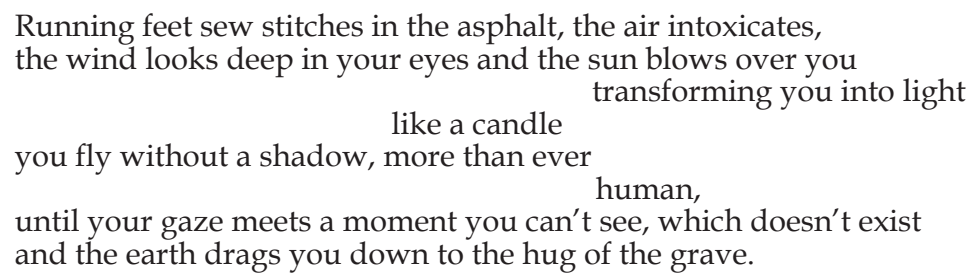

Psychosis is a multifaceted phenomenon. It can be and often is a painful experience for the individual and her/his social network. On the other hand there are many who experience aspects of psychosis - for example the hearing of voices as valuable. In addition, there are a variety of clinical approaches to psychosis, exhibiting both similarities and contradictions. The scientific literature on psychosis, too, is diverse and in part conflicting. Hence, psychotic crises constitute a challenge to professionals, not least psychiatrists. An additional complicated phenomenon is the inner dialogue of professionals, which was the focus of this research. This introduction aims to describe the diverse characteristics of the research theme.

The Need-Adapted Approach (NAA) (Alanen, 2009) constitutes an effort to bring together the person having the psychotic experience, her/his social network, and all important professionals, in order to meet the challenges of the psychotic crisis. In NAA the psychiatrist works as part of a team, and the treatment aspects are discussed and decided on together with the patients, family members, and staff during therapy meetings (Rakkolainen, Lehtinen, \& Alanen, 1991). The participants are guided by a psychotherapeutic attitude in which the aim is to achieve a common understanding of what has happened, and to evaluate the real and changing needs of the patients and the family. In addition, concrete treatment plans are drawn up and continually revised within therapy meetings. The purpose is to work with the experiences of the clients, and to avoid the dominance of a medical perspective that might involve unnecessary treatments. In NAA the psychiatrists should be able to hear and consider all the 
voices present in the therapy meeting, including the scientific and institutional voices of the profession. For a genuine discussion to take place, the psychiatrists need to be able to tolerate the insecurity they feel within themselves, and at the same time be willing to take on legal and medical responsibility, so as to be able to make crucial decisions.

The aim of this research was first of all to describe the inner dialogues of psychiatrists during the psychosis treatment process, while co-operating with the patient, her/his social network, and other professionals. This situation forms the context of NAA in the treatment of psychosis. Secondly, it strived to describe (as indicated by the title of the thesis, which uses a quotation from a psychiatrist involved in the research) how the embodied experiences of professionals can have an impact on the treatments applied. The third goal was to clarify how one may set about studying the phenomenon of professionals' inner dialogues.

From the very beginning, the research had - for a scientific project somewhat personal characteristics. First of all, as a practitioner I have been interested in studying my own inner dialogue(s) since my upper-level family therapy training, for which I did diploma work based on written imaginary discussions between myself as a client and myself as a therapist (Borchers, 1999). Secondly, I have experienced personally the professional challenges associated with specific features of the psychosis phenomenon, as a psychiatrist, a familytherapist, and a supervisor. A fictitious case story which I wrote (Borchers, 2009) illustrates the contradictions in the sense of agency that I experienced in trying to integrate the stance of NAA with other approaches, in relation also to personal and institutional impacts. All in all, I can say that the research as a whole had major impacts on me, both as a professional and as a person.

Although some attention has been paid to psychotherapy professionals' experiences, inner dialogues seem to have been almost entirely ignored in recent psychiatric scientific discourse. In this sense, the present research is connected to critical psychiatry as defined by Bracken and Thomas (2010) and forms part of a scientific discussion which has been continuing over recent decades, touching on academic psychiatry and the treatment of psychosis. The 1990s was referred to as the "decade of recovery" by William Anthony (Anthony, 1993, 2006; Anthony, Rogers, \& Farkas, 2003), a professor of psychiatry who (based largely on his own experiences of receiving the diagnosis of multiple sclerosis) has emphasized the need to encourage hope and empowerment among persons with severe mental disorders. According to Kissling and Leucht (1999) the gap between the actual and the possible outcome of schizophrenia indicates that the psychiatric researcher should focus more on naturalistic studies, and on the medical decision-making conducted in real-world practice. Bracken and Thomas (2001) have used the concept of postpsychiatry for their postmodern approach, which emphasizes social and cultural contexts, places ethics before technology, and interprets experiences of psychosis as meaningful rather than as simply psychopathological. Rose, Thornicroft, and Slade (2006) have expressed the need for a multiple paradigm on evidence, one that would take into account different stakeholders' perspectives on mental health care. In 
an interview with the New York Times, Nancy Andreasen, an outstanding psychiatrist and neuroscientist, has noted (Dreifus, 2008) that according to longitudinal MRI studies on first-episodic schizophrenia patients, the more antipsychotic drugs one is given, the more brain tissue one will lose. Morrison et al. (2012) have argued that the disadvantages of antipsychotics have been underestimated, and correspondingly, that their effectiveness has been overestimated. He concludes that antipsychotics should not always be the first line treatment for people with psychosis. From the editor's desk of The British Journal of Psychiatry, Tyrer (2012) has called for an end to the psychopharmacological revolution of 1952. Generally speaking, there have been serious arguments to the effect that academic psychiatry should move beyond the dominance of the current neurobiological paradigm, and should focus more on the role of psychiatrists as agents within a social context (Bracken et al., 2012; Priebe, Burns, \& Craig, 2013). Thomas Szasz, the writer of "The Myth of Mental Illness" (1960), has taken the view that fifty years on from his essay he sees no need to change his view that mental illness is a metaphor, one that is used as a means of control as an alternative to personal care (Szasz, 2011).

In Finland the development of NAA, which started in the 1960s (Alanen, 1997), has been closely linked to nationwide projects (Aaltonen et al., 2000; Lääkintöhallitus, 1988) aimed at improving the treatment of schizophrenic psychosis. NAA probably constituted a kind of unofficial national approach, up until the 1990s. The first evidence-based Current Care Guidelines for Schizophrenia (CCGS) were published in 2001. Here, it is difficult to say how much the various treatment recommendations have actually affected practice. However I would take the view that since the 1980s the focus has changed from a biopsychosocial perspective towards a more neurobiological one. In spite of the variation in different areas and even within the same organization, in practice this has often meant that antipsychotic medication is the primary method of care, even if approaches such as cognitive therapy and family psychoeducation are highlighted in the current guidelines (Working group appointed by the Finnish Medical Society Duodecim and the Finnish Psychiatric Association, 2013).

One of the exceptions to the general trend has been the Open Dialogue Approach (ODA) of Western Lapland (Aaltonen, Seikkula, \& Lehtinen, 2011; Seikkula et al., 2006; Seikkula, Alakare, \& Aaltonen, 2011; Seikkula \& Arnkil, 2005) which is based on NAA. In 2005, at the time when I began this research, it appeared that there were confusing differences in the guidelines for the treatment of psychosis (Finnish Medical Society Duodecim, 2001; Gleeson \& McGorry, 2005; Read, Mosher, \& Bentall, 2004: Seikkula et al., 2003; Topor, 2004). In addition to the many emotional challenges raised by psychotic speech or behavior in actual clinical discussions, psychiatrists can be confused by the theoretical contradictions that have emerged (Borchers, 2009). NAA is based to a large extent on a social constructivist ${ }^{1}$ view which accepts the absence of ultimate truth

1 Term social constructivism is closely related to social constructionism, which contends that knowledge is created through social interaction, but focuses more how social relationships influence on individuals' cognitive processes (Young, 2004). 
(Burr, 2004), and which tries to open a dialogue between the different perspectives. Here one can identify a major contradiction with the biomedical education of psychiatrists and their hierarchical position in medical institutions.

There is considerable research indicating that NAA is an effective approach (see e.g. Aaltonen, Seikkula, \& Lehtinen, 2011; Alanen, 1997; Bola et al., 2006; Gromer, 2012; Saari, 2002; Seikkula, Alakare, \& Aaltonen, 2011). Since the approach aims primarily at dialogue and at a common understanding between the patient and her/his social network - rather than at controlling the psychotic symptoms which per se arouse anxiety and other difficult emotions - it is often exceptionally challenging for the staff concerned. The rich qualitative research on NAA (e.g. Holma, 1999; Iso-Koivisto, 2004; Piippo, 2008; Seikkula, 1991) deals partly with the treatment challenges facing professionals (Aaltonen et al., 2000: Haarakangas, 1997: Seikkula, 2002). Nevertheless, this present research is the first to concentrate on the professionals' experiences of NAA.

Since psychiatrists' inner dialogues seem to be dependent on several aspects connected with psychosis, this introduction begins with an extensive description of the phenomenon, and it also describes the treatment traditions and their contradictions. Thereafter, attention is given to the concept of inner dialogues - especially as a phenomenon among psychiatric professionals working with psychotic patients - and to the therapeutic relationship that is brought into being. Section 1.5 summarizes the research questions pertaining to the research as a whole, and also the research questions for the three studies.

\subsection{The psychosis phenomenon}

The variety and contradictions among psychosis concepts constitute one of the main challenges for psychiatrists. Here I should note that the title, "the psychosis phenomenon" was chosen to emphasize the historical, interactive, experiential, and social constructivist nature of the concept. In my view there is a mutual interdependence between psychiatrists' inner dialogues, the characteristics of psychosis, and the ways in which the phenomenon can be understood and described.

\subsubsection{The conceptual background}

In traditional terms, psychosis is a diagnostic concept referring to an observer's perceptions of another person as having peculiar symptoms. The NAA research tradition has used the concept of schizophrenia-spectrum psychosis, referring to an ICD-10 diagnosis of F20-29. Experiences which are labeled as psychotic symptoms pose challenges to normality and to the human agency of an individual, and they arouse considerable anxiety, despair, and uncertainty in social relationships. Through laws pertaining to compulsory treatment and forensic psychiatry, democratic societies as a whole have dealt with psychosis in a very different manner from most other health or psychosocial divergences. The main 
Finnish textbook of psychiatry (Lönnqvist et al., 2011) states that a psychotic person interprets external reality in a clearly different way from others. From the narrowest perspective, psychosis is defined as the manifestation of delusions or hallucinations in which the person experiencing them is unaware of their pathological nature. According to Cullberg (2005), psychosis is a phenomenological and psychological concept which cannot be applied in the absence of the concept of delusion: one may have hallucinations, but if she or he doesn't interpret the perceptions as delusional, they are not psychotic.

Several authors see the history of the schizophrenia concept as largely based on a population suffering from organic disorders; this is seen as having contributed to the myth of schizophrenia as a progressive and incurable brain disease (Cullberg, 2005; Read, 2013b; Whitaker, 2003) - despite the fact that this view is not supported by longitudinal neuroimaging studies (Zipursky, Reilly, \& Murray, 2013). A strictly causal illness model of psychosis and schizophrenia has been replaced by a vulnerability-stress model, which emphasizes immediate triggering stressors - including biological or psychological vulnerabilities but also protective factors (Cullberg, 2005). However in real-world clinical practice it is still common to hear staff speaking of a "process illness," referring to an inevitably devastating brain condition.

Questions have been raised about the current psychiatric taxonomy, concerning in particular the reliability and validity of the diagnosis of schizophrenia (Bentall, 2013; Read, 2013a). Critics have proposed dimensional measures of mental health, with a greater focus on clients' needs and quality of life. In relation to psychotic disorders, Os and Kapur (2009) have put forward a fivedimensional model consisting of positive, negative, and cognitive symptoms, plus depression and mania. Furthermore, clinical language can easily disregard people's subjective experiences. According to Geekie and Read (2009) lay terms such as "madness" can give value to clients' perspectives better than concepts which are firmly rooted in the medical tradition. They argue that the ongoing debate between different theories of schizophrenia is necessary if the concept is to gain a more relevant and more comprehensive meaning. According to Cullberg (2005) the term schizophrenia is in practice used as a synonym for a chronic model of psychosis - a condition from which, in fact, half of those thus diagnosed can recover. Here one should also note the increasing scientific discussion on the causal role of childhood adversity in many mental health problems, and in particular the similarities observed in trauma-associated diagnoses such as psychosis (or schizophrenia) and dissociative disorder (e.g. Read, 2013c).

The symptoms of psychosis challenge common sense and conventional ways of interacting, and lead to emotional uncertainty. Professionals have become accustomed to evaluating psychotic persons using negative terms, referring to a lack of insight or awareness, denial of the illness, noncompliance, nonadherence, and a lack of cooperation. This stance involves focusing on symptoms and pathology while ignoring the actual meaning of the psychosis, the 
resources of the patients ${ }^{2}$ and their networks, and the impact of the interaction on professionals and on society. Compliance and treatment adherence are terms used mostly in the scientific literature (Kampman, 2005). The concepts have a sociological origin, understanding patients as active, equal interlocutors having expertise of their own. For the most part, practitioners see compliance - or lack of it - only as a quality of the patients though it is much more complicated issue of the whole context of the treatment. Compliance is used also as a concept underlining the exercise of power (Sorvaniemi \& Kampman, 2000). Cullberg (2005) criticizes the use of the term "compliance" seeing it as signaling authoritarian thinking, and as requiring the obedience of patients. It is argued that terms such as co-operation - or a (therapeutic) alliance - may be more appropriate, since they include also the compatibility of the interaction.

McGorry and McConville (1999) question the way in which the multidimensional and continuous construct of insight has been used in the field of psychosis. Conflicts between the clinician and the patient are often interpreted as demonstrating a lack of insight on the part of patient. In fact, most patients have some awareness of a change in their mental stage. First-episode psychotic patients seem to be somewhere between the extremes of identification and denial. Although they are willing to discuss some aspects of their symptoms in detail, they are not ready to label themselves as mentally ill. According to McGorry and McConville this attempt to protect self-esteem and to avoid internal stigmatization assists recovery; among adolescents in particular, a reluctance to accept illness can be a sign of health and a refusal to give up hopes of a return to normality. Patients who have accepted their diagnosis of psychosis have been shown to experience lower control over their disorder (Read, Haslam, \& Magliano, 2013). According to experience and also some research (Kaffman, 1984) there is always a basis of truth behind paranoid beliefs: occasionally, instead of being the basic problem, they may be part of the solution. Many socially able persons experience their voices or deviant beliefs as being in some ways meaningful (May, 2005). Based on their own and other recent studies Moritz et al. (2013) have suggested not all patients suffer from psychotic symptoms, which instead are associated with self-reported emotions that are both positive and negative. According to Topor (2004) most patients have a double consciousness: although at times they feel that an alien part of themselves is colonizing them, on other occasions they are capable of reflecting and having inner and outer dialogues concerning their strange thoughts or perceptions.

2 An important aspect of the psychosis phenomenon is the words used in the discourse. In English the word user would be preferable to patient, since the latter places persons in a more passive and dependent position. However the word user in Finnish (kuluttaja, palveluiden käyttäjä) has a different tone, and is not used in the context of Finnish psychiatry. I would have preferred to speak of "persons having psychotic experiences," but due to the length of that expression, I have used a variety of expressions according to the context. The word client is used when reference is made to both patients and their family members. When dealing with psychosis the concept of a disorder is preferred. The concepts of illness and schizophrenia are used if they are needed for a proper understanding of the text in a given context. 


\subsubsection{The recovery approach}

There are several aspects of the recovery approach which might be useful for psychiatrists in terms of co-operating with clients and maintaining long-term hope in real-life clinical practice. The recovery approach challenges the psychiatric perspective on psychiatric disorders such as psychosis, especially the notion of an inevitably chronic illness, and offers an alternative to medical concepts and language (Jacobson \& Greenley, 2001; Lester \& Gask, 2006; Roberts \& Wolfson, 2004; Topor, 2004). Though there have always been patients who have recovered, they are not seen so frequently in common clinical practice, and thus have tended to be overlooked in clinical discussions. The recovery approach has succeeded in giving those persons a voice.

Recovery (Anthony, 1993; Anthony, Rogers, \& Farkas, 2003) is defined as a way of living a satisfying, hopeful and contributing life even with the limitations caused by an illness or a disorder. It involves the development of new meaning and purpose in a person's life after growing beyond the catastrophic effects of mental disorder. All in all, recovery is a unique process of change, and one that is deeply personal. Instead of emphasizing the disorder and the symptoms, the approach focuses on recovering from the stigma, from the iatrogenic effects of treatment, from the lack of opportunities for self-determination, and from crushed dreams; these can indeed be more difficult goals than recovery from the disorder itself. Major recovery may occur without complete symptom relief. Clients are the main agents in the recovery, which can occur without professional intervention. If clients do ask for help, the professional's task is to facilitate recovery. Being available, and in particular, maintaining hope, are often more important than the official treatments. The recovery paradigm focuses on health and well-being and the study of resilience. It is more interested in finding out what contributes to recovery than in the risk factors.

The medical concept of relapse is in contradiction with that of recovery, which can occur even if symptoms recur. Progress is not linear: periods of insight or growth happen unexpectedly. Illness and wellness can be seen as independent variables (Roberts \& Wolfson, 2004). Recovery is not synonymous with cure; it is better captured by the notion of healing, which involves defining a self apart from the disorder and control (Jacobson \& Greenley, 2001). Recovery is in the deepest sense a social process: connections with one's personal social network and with society as a whole are of major importance for those who recover.

\subsection{Experiences of psychosis, treatment, and recovery}

There appears to be a mutual interdependence between the impact of psychosis on the treatment processes, the human experiences of clients and professionals, and the institutional factors of psychiatry. From this perspective, the entire context of the treatment should be considered for an understanding of psychiatrists' 
inner dialogues. Studies have been conducted on users' experiences, including their understanding of psychosis (e.g. Geekie \& Read, 2009; Topor, 2004), with attention given also to the experiences of family members (e.g. Stern et al., 1999). Nevertheless, the embodied human responses of professionals have largely been ignored in recent scientific psychiatry.

\subsubsection{The experiences of service users}

There have been a good many first person accounts of experiences of psychosis, and of treatment and recovery. For example, when Rufus May (2005) studied as a clinical psychologist, he was motivated by his negative experiences of treatment during his own psychosis as a youth. He describes the care he received as ideological in nature, relating to attempts that were made to make him believe he had a severe mental illness. Like many others, he decided to give up the treatment, and this made a crucial contribution to his recovery. He learned to live with his unusual thoughts and experiences so that they made his life richer.

Research on the narratives of recovery shows that users are willing and able to take account of diverse views on psychosis, and to integrate them (Geekie \& Read, 2009). The essential element is not the scientific relevance of the accounts, but their usefulness for the users in constructing a coherent story (Topor, 2004). Individuals with psychosis favor psychosocial over medical explanations of their experience (Dudley et al., 2009; Hirschfeld, Smith, \& Griffin, 2005; Lobban, Barrowclough, \& Jones, 2003). The subjective experiences of psychosis given by users have been described via the concepts of sealing over and integration, which constitute two opposite ends of a continuum (Geekie \& Read, 2009). Persons who seal over tend to have fixed and negative views of their psychotic experiences, seeing them as having little personal significance. The integrators who seem to get along better - express interest and curiosity about the experience, and this aspect is related to their life and to their opportunities to develop. The stances taken are in each individual case influenced by clinicians' understanding of and emphasis on the biological nature of the illness, and by the life experiences of the users. According to the study by Geekie and Read, users profit not so much from answers but from a genuine collaborative exploration of the nature and meaning of the experiences, and of their emotional validation. Spirituality - which is one of the main broad frameworks of meaning for psychotic experiences - has mostly been neglected by clinicians.

According to Topor (2004) persons who have recovered from severe mental disorders come under a kind of curse: either their past experiences or their recovery will be questioned. The individuals studied by Topor described their recovery as an evolutionary process of change, one that often had a turning point, and occasionally a bottom point, experienced as a dead end. The pessimistic expectations of professionals increased learned inability and slowed down recovery. Diagnostics had a major impact on those concerned, who experienced a loss of themselves as normal human beings and a sense of being transformed merely into a disorder. The experiences of interventions had their own 
histories: thus, for one individual the experience of spending eight days in a closed ward was a kind of hell, while for another - perhaps because of one friendly student - it was felt to be an opportunity. Most service users considered medication to be one important means of recovering, but many of them associated well-being with not being on drugs. Altogether, the main issue was one of appropriate listening to users. They needed to be approached as human beings who were trying to deal with their lives, as persons having both a disorder and health. It was also important that the professionals should show sympathy or a degree of acceptance of their views. Another important factor was the opportunity to offer something to those who had made a major contribution to their recovery. The personal characteristics of the professional - whom they preferred to be able to choose - were often more important for service users than the treatment method. The users appreciated flexibility a willingness to accept small risks and to make exceptions to the conventions of professional practice, and continuity. One of the challenges for professionals is to recognize and accept factors outside the treatment context that could support recovery. According to Topor the experiences of users indicate that in addition to conventional professional practice, there is a need for something that might be called professional friendship.

Many service users describe the process of stigmatization - by others and by oneself - as more lasting and disabling than the psychosis itself. The core experiences of the process are low self-esteem, shame, and blame. People with a diagnosis of schizophrenia are particularly likely to be face discrimination concerning social relationships and working life. The stigma does not merely have negative effects within the treatment process (for example by increasing the duration of untreated psychosis): it also exposes the individual to major inequalities and poverty (Campbell, Byrne, \& Morrison, 2013; Read \& Magliano, 2012; Thornicroft et al., 2009). From interviews with participants with schizophrenia in 27 countries, including Finland, Thornicroft et al. (2009) found that experiences of discrimination in many domains of life were related to prior coercive mental health interventions.

\subsubsection{The experiences of family members}

First-person accounts of the experiences of relatives with the role of carers are available, for example in the British $\mathrm{NICE}^{3}$ guidelines on schizophrenia (The Schizophrenia Update Guideline Development Group and National Collaborating Centre for Mental Health, 2010). There is abundant evidence that the family members of psychotic persons have difficult and complex emotional experiences, including difficulties in accepting the situation, looking to the future, and changing roles within the family (Addington \& Burnett, 2005; Addington et al., 2003; Askey \& Gray, 2009; Gerson et al., 2009; Hultsjo, Bertero, \& Hjelm, 2009; Read \& Magliano, 2012; Read \& Seymour, 2013; Sin, Moone, \& Harris, 2008). Many carer-relatives have encountered at least moderate aggression and trau-

3 The acronym refers to the National Institute for Health and Care Excellence. 
ma, sometimes resulting in symptoms of posttraumatic stress disorder (Askey \& Gray, 2009; Barton \& Jackson, 2008; Loughland et al., 2009). The relatives themselves face prejudice and stigma (Addington \& Burnett, 2005; Hultsjo, Bertero, \& Hjelm ,2009; Read \& Magliano, 2012; Sin, Moone, \& Harris, 2008) occasionally resulting in isolation (McCann, Lubman, \& Clark, 2012), barriers to help-seeking (Tanskanen et al., 2011), or problems in co-operating with professionals (Gerson et al., 2009). In a German focus group study (Angermeyer, Schulze, \& Dietrich, 2003) the professionals were important sources of the "double stigma" experienced by relatives of patients diagnosed as having schizophrenia: they themselves suffered from public images of mental illness and the abusive psychiatric practices applied to the psychotic family member. The experiences of primary caregivers with regard to clinicians' responses seem to be contradictory (Askey \& Gray, 2009; Gerson et al., 2009; Hultsjo, Bertero, \& Hjelm, 2009; McCann, Lubman, \& Clark, 2011, 2012; Tanskanen et al., 2011). All in all, from research on the positive and negative experiences of carers it appears that they need to be sensitively listened to by professionals who are willing to act like human beings; they also need individually based information, knowledge of where to seek help, recognition of their contribution to the treatment, and organizational flexibility. In fact, siblings have tended to be excluded both from research and from treatment - this despite their position which is quite different from that of e.g. parents and their potential value as recovery agents (Sin, Moone, \& Harris, 2008).

According to the interview study by Stern et al (1999), the family members of patients with a severe mental disorder such as psychosis needed a platform upon which they could reconstruct a sense of personal identity, in order to locate the disorder coherently with their worldview. There was a sense of the future having collapsed and of being obliged to live in a day-to-day fashion. They needed time to accept the disorder, and their ability to structure time was facilitated by the forming of a narrative - a narrative that had to be modified according to the needs of the process. The strategies of coping and attitudes to symptomatic behavior were logical continuums of the stories of the family members themselves. Help came from stories which supported a friendly attitude towards the incomprehensible aspects of psychosis, and possibilities to see the disorder as providing an opportunity.

According to Read and Magliano (2012) family members tend to believe that their relative's difficulties are caused by life events rather than by biological factors. However, most of the research on families' experiences of psychosis has been based on a neurobiological approach. The concept of expressed emotion (EE) was designed to create an impression of non-judgmental neutrality and avoidance of blame of family members - even if the three components (hostility, criticism, and emotional over-involvement) are not neutral words (Read \& Seymour, 2013). In recent years, studies have indicated that EE is not a stable index, but one that rather reflects complex case-specific dynamic interaction processes (Burbach, 2013; Cutting, Aakre, \& Docherty, 2006; Read \& Seymour, 2013; Treanor, Lobban, \& Barrowclough, 2013). According to Ad- 
dington and her associates (Addington \& Burnett, 2005; Addington et al., 2003), it is the family's appraisal of the impact of the disorder on themselves (and not the severity of the actual symptoms) that is the most significant predictor of poor psychological well-being. A study by Treanor et al (2013) is exceptional in this research tradition, in that it focuses on relatives with low EE. The research found that the relatives became better able to adjust to uncertainty as an alternative to trying to control the future. Thus, they were able to accept the situation and its consequences, focusing their energy on supporting their family member; this was also closely related to the relatives' capability to maintain hope. The relatives built a normalizing model from which to understand psychosis, and had many different, sometimes unconventional ways to deal with the stressful situations.

\subsubsection{The experiences of professionals}

According to the phenomenological approach of Fuchs and de Jaegher (2009) which is based largely on evidence of the role of social interaction in the development of mirror neurons in early childhood - social understanding is a process in which the live bodies of the participants form a common incorporality. Since psychotic experiences are obscure and contradictory, and are hard or even impossible to verbalize, the professionals, as embodied agents, are bound to be confused in their attempts to interact and coordinate themselves with the patient. Hinshelwood (2013) claims that professionals treating psychotic persons tend - as a means of coping with what is meaningless - to maintain a separation from these confused feelings and meanings, resulting in emotional distance.

There have been some emotionally touching first-person accounts of professionals' experiences of mental health in-patient care (Hardcastle et al., 2007), plus a few studies on the experiences of professionals. According to this somewhat limited literature, professionals seem to distance themselves from the emotional challenges bound up with psychosis by creating a diagnostic culture (Tzeng \& Lipson, 2005), they may avoid patients with psychotic crisis altogether (Oud et al., 2007) or they may classify the person with a schizophrenia diagnosis as being very dissimilar to themselves (Servais \& Saunders, 2007). Concerning psychosis, it is clear that the causal beliefs of professionals tend to be based on a neurobiological illness model more than those of the public, patients, or family members, with the latter all generally tending towards a psychosocial understanding (Read, Johnstone, \& Taitimu, 2013). In hospitals in particular, professionals experience the aggressive behavior of the patient, resulting in negative feelings and even symptoms of posttraumatic stress disorder (Erdos \& Hughes, 2001; Rossberg \& Friis, 2003). On the other hand, it appears that patients perceive the actions of the staff such as giving medication as provocations, and that this is not recognized by the professionals (Omérov \& Wistedt, 2004). A high level of EE among staff has been found to have an impact on the wellbeing of professionals within their work (Dennis \& Leach, 2007); moreover, the 
dual-role dilemma ${ }^{4}$ causes major moral distress for professionals (Austin, 2008; Marangos-Frost \& Wells, 2000; Robertson \& Walter, 2008).

Out of all the research on professionals' experiences located for this research, only one study - dealing with nurses' responses in cases of postpartum psychosis (Engqvist \& Nilsson, 2009) - seems to catch the profoundly human nature of the position of professionals. The nurses in that study reported having strong emotional responses which included both happiness and sadness, and comparisons of their joy of parenthood with the distress experienced by their patients. Their description of the patients having "strange eyes" seems to be an observation, and at the same time a relational description containing something of the experience of the inner dialogue of the nurses.

Even brief psychotherapeutically oriented training has been found to influence the attitudes and emotional responses of staff members working with psychosis (Berry \& Wearden, 2009; McLeod \& Hogbin, 2002). Among staff members, a variety of personal characteristics, including emotional flexibility, have been found to have impact on therapeutic relationships (Berry \& Wearden, 2008; Holmqvist, 1998; Holmqvist \& Armelius, 2006). These seem to predict the outcome of patients (McCabe \& Priebe, 2004; Priebe et al., 2011), and they can help patients to experience even compulsory care as something positive (Sheehan, 2009).

\subsubsection{Social and institutional perspectives}

The phenomena of involuntary treatment and forensic psychiatry underline the fact that democratic societies deal with psychosis in a difference manner from most other health problems. Within Europe there are differences in legislation regarding the compulsory treatment of psychotic patients; moreover, societal attitudes and traditions rather than clinical factors seem to be responsible for the substantial variations in the application of coercive measures across countries (Jacobsen, 2012; Raboch et al., 2010; Sheehan, 2009). From research on the history of madness and psychiatry and from a critical analysis of an abundance of psychiatric studies and documents, several writers have claimed that the past and present approach to psychosis is largely a matter social control - albeit camouflaged in expert theories (Cullberg, 2005; Read \& Dillon, 2013; Whitaker, 2003). Ever since the introduction of chlorpromazine, the pharmaceutical industry has had a major influence, not merely on the treatment of psychosis, but also on research, professional organizations and teaching institutions, and public opinion (Mosher, Gosden, \& Beder, 2013).

According to a summary derived from 84 studies on people from 25 countries (Finland was not included), the general public place more weight on psychosocial than on bio-genetic notions of psychosis, with a corresponding preference for psychosocial solutions (Read, Johnstone, \& Taitimu, 2013). Neverthe-

$4 \quad$ A quandary in which professionals face conflicting expectations or responsibilities between the therapeutic relationship on the other hand and the interests of a (powerful) third party on the other 
less, stigmatizing attitudes fueled by the media seems to be worsening (Read, Haslam, \& Magliano, 2013). It has been claimed that this is partly due to efforts to put across to the public the views of biological psychiatry, with websites funded by drug companies having a role in this (Read, 2008; Read \& Cain, 2013; Schomerus et al., 2012). Based on overviewing large amount of studies a number of critical authors (see e.g. Read, 2013c; Read \& Beaven, 2013; Read, Johnstone \& Taitimu, 2013; Whitaker, 2003) has suggested that social factors such as child abuse, poverty, racism, and gender issues are causative factors for psychosis - yet such findings have largely been ignored, or else they have been interpreted in ways that maintain the dominance of bio-genetic theories. Read and Dillon (2013) speculate that the medical model may have been allowed to dominate because it helps people to deny unpleasant facts and to distance themselves from those who have suffered from the ways humans mistreat each other; moreover, it gives politicians an excuse to do nothing about the social problems underlying distress. Of interest here is a study by Clements and Davies (2013), who conducted a search on over a hundred thousand studies on schizophrenia and psychosis up to January 2012; the researchers found that fewer than 0.1 percent of the studies focused in any way on primary prevention.

Psychiatric hospitals are a special kind of institution, partly because of their legal task of taking care of involuntary treatments. Such a role can lead to a focus on pathology as a means of justifying the coercion used. Here it is worth recalling the work of Goffman (1961), who wrote a classic account of asylums in the 1960s. One can see that in many respects his account still applies to the mental hospitals of today. Patients tend to lose most of their personal control; they learn to behave according to the rules of the institution, and are confronted with isolation, involuntary medication, and forced social relationships. The staff still runs the risk of becoming demoralized, adopting stigmatizing attitudes, and losing touch with their humanity. Although mental hospitals have a normative control function, this is still largely kept hidden: the general public is probably satisfied when institutional procedures and individual decisions are explained as resulting from the medical needs of patients. Experiments by Rosenhan (1973) showed how readily the conventions in psychiatric institutions reasserted themselves: after researchers pretending to hear voices were labeled as having psychosis, their behavior and speech were interpreted as displaying signs of pathology. Family therapists Haley (1980) and Elizur and Minuchin (1989) have described how institutional patterns, such as the medical framing of problems, also make parents more dependent on professional guidance, with correspondingly less power and agency.

In the today's society psychosis is mostly considered from the perspective of natural science and medicine. According to the social constructivist perspective, one's understanding is always historically and culturally relative and dependent upon the particular social and economic arrangements and power relations at a given time (Burr, 2004). Language about mental illness is not to be seen as neutral but as having a powerful function, with implications for the way people are treated. From this point of view, illness is not so much a physiologi- 
cal as a social phenomenon, and one that is dependent on the interpretation of our experiences - which in turn depends more on the social than the individual realm.

Foucault's writings on knowledge and power are essential in understanding institutional or social aspects of madness, or of mental disorders in general (see e.g. Alhanen, 2007; Bracken, Khalfa, \& Thomas, 2007; Bracken \& Thomas, 2010; Burr, 2004; Foucault, 1975, 1980; Hall, 2003; Roberts, 2005; Stevenson \& Cutcliffe, 2006; White \& Epston, 1990). Although involuntary treatment is a clear example of oppressive power, Foucault claimed that more characteristic of modern societies is the constitutive effect of power, operating via normalizing discourses incorporating ideas that have been given a truth status. According to Foucault it was not inevitable that madness would be seen as an illness. In relation to psychosis, Foucault's idea of power as something that produces reality is of particular importance. From this point of view, scientific knowledge and classifications, statistically based norms, and diagnoses are ways to make human beings subjects of their own control. The "disindividualized normalizing gaze" of psychiatry can be seen as functioning throughout the community. Not merely professionals but also family members are educated to look for early warning signs or to see the importance of continuous medication, and patients, too, are invited to become subjects, i.e. persons who exist as objects for themselves. They are asked to control their own thoughts, feelings, and behavior with respect to psychiatric knowledge, whose status of possessing unitary and global truth - and of having the dominant narrative - is based on discourses in the scientific community, in the media, and in society as a whole. For their part, professionals are monitored by public authorities and experience the everpresent gaze of society. In this process of control, written documents are of major importance. From the Foucauldian point of view, the resistance of patients to psychiatric power-knowledge relations can be seen as a legitimate demand for dialogue.

\subsection{The treatment of psychosis}

There are several different treatment approaches to psychosis. In part these share common aspects, but there are also differences and even contradictions. I shall here concentrate on introducing the Need-Adapted Approach (Alanen, 1997, 2009), including also the Open-Dialogue approach (ODA) (Aaltonen, Seikkula, \& Lehtinen, 2011; Seikkula, Alakare, \& Aaltonen, 2011). These constituted the focus of this research. It should also be noted that the main principles of a recovery-oriented service (NIMHE, 2005) strongly include the voice of the clients, with important implications for the treatment culture currently surrounding psychosis in Finland; hence I shall briefly set out these principles. Thereafter, in Section 1.3.3 I shall present a critical overview of the evidencebased Current Care Guidelines for Schizophrenia (CCGS) (Working group ap- 
pointed by the Finnish Medical Society Duodecim and the Finnish Psychiatric Association, 2013).

\subsubsection{The Need-Adapted Approach (NAA)}

NAA is based on experiences and research that began in the Clinic of Psychiatry in Turku during the 1960s, under the leadership of Professor Yrjö Alanen. From an early date, the main goal was to develop the psychotherapeutic treatment of schizophrenia-group psychoses for multiprofessional teams in the public sector. The development of the model was associated with the Finnish National Schizophrenia Project in the period 1981-87. The main research strategy has been that of action research, using patient cohorts collected at different times. This policy has been useful in making changes to the treatment model according to research evidence, with subsequent evaluation of the new modification in the follow-up of the next cohort (Alanen, 1997).

Over the decades the orientation of NAA has changed from milieu and psychodynamically oriented individual therapies to family therapy, with first of all a systemic emphasis (e.g. Selvini et al., 1980) and later a narrative (e.g. Holma, 1999) and especially a dialogical (e.g. Seikkula \& Olson, 2003) emphasis. NAA highlights the importance of the patient's presence in the situations that concern her/him and the treatment. The psychotic behavior of patients is considered from a systemic viewpoint, as a relational phenomenon occurring in a network which includes the patient and her/his family, plus other important persons and professionals (Alanen et al., 2000). The general principles of NAA are:

(i) Therapeutic activities are carried out flexibly, to meet the real and changing needs of each individual patient and her/his meaningful social network.

(ii) The psychotherapeutic attitude constitutes an effort to establish a therapeutic relationship and to understand the situation of the clients.

(iii) As an alternative to either/or approaches, different therapeutic activities complement each other.

(iv) The continuity of the treatment is protected so that it is a genuine relationship process; within it not merely the clients but also the professionals learn and change.

(v) Both individual and organizational follow-up are important for the development of treatment units and the system as a whole (Alanen, 1997, 2009).

Two additional NAA principles have been formulated, based on the findings of the most recent national research and development project, called the Acute Psychosis - Integrated Treatment Project (API) (Aaltonen et al., 2000), conducted during the 1990s. These principles are defined as horizontal expertise and deritualization of the treatment.

In NAA psychiatrists work as part of a case-specific multiprofessional team, and treatment aspects are discussed and decided on together with the patients, family members, and staff during therapy meetings (Alanen, 1997; 
Rakkolainen, Lehtinen, \& Alanen, 1991). The intention is to work with the experiences of the clients, and to avoid the dominance of a medical perspective that might involve unnecessary treatments. One aim is that neuroleptic medication should be postponed in the initial phase. The basis of the NAA tradition is not immediate control of the psychotic symptoms but the formation of a dialogue with patients and other participants within therapy meetings. As a means of avoiding hospitalization, acute psychosis teams, who arrange therapy meetings in an outpatient setting, have been established in many parts of Finland.

The Open-Dialogue Approach (ODA), which is a modification of NAA, has been systematically developed since the beginning of the 1980s in the Western Lapland region of Finland. Based on developments in the approach, and (since the late 1980s) continuous research, the following seven treatment principles have been crystallized:

(i) The first meeting should be organized immediately, i.e. within 24 hours of contact being made.

(ii) The private as well as the professional network of the patient should always be invited to participate.

(iii) The treatment and therapy methods should be flexibly adapted to the specific needs of the clients.

(iv) The system should guarantee that specific professionals will take responsibility for the treatment, organizing a case-specific team that will work according to NAA principles.

(v) The team should aim to guarantee psychological continuity, for example by inviting professionals from different organizations to collaborate.

(vi) By promoting a sense of security the team should aim to generate a therapeutic process that tolerates uncertainty.

(vii) In the therapy meetings the team should focus on generating a dialogue, in order to create a new joint language for (psychotic) experiences that previously did not have words. To increase the possibility of genuine dialogue, therapy meetings are not prepared in advance, specific interview methods are avoided, the language of the clients is listened to, their words are used, and the themes of the professionals are preferably left for discussion at the end of the meetings.

The majority of the staff of the Western Lapland psychiatric catchment area have been trained as family therapists in systematic culture-syntonic training programs that have operated since the late 1980s (Aaltonen, Seikkula, \& Lehtinen, 2011; Seikkula et al., 2006; Seikkula, Alakare, \& Aaltonen, 2011; Seikkula \& Arnkil, 2005).

There is an abundance of research on the usefulness of NAA. Studies conducted in Western Lapland have shown important results from a systematic long-term process of development: the mean annual incidence of schizophrenia has decreased, the numbers of new long-stay hospital patients having a diagnosis of schizophrenia have fallen to zero, the duration of untreated psychosis has shortened, and the majority of recent patients have returned to their working 
lives (Aaltonen, Seikkula, \& Lehtinen, 2011; Seikkula et al., 2006; Seikkula, Alakare, \& Aaltonen, 2011). The approach has also shown itself to be more economical than conventional psychiatric treatment (Lehtinen, 1993; Saari, 2002). Although the roots of NAA are in Finland, studies have also been conducted in other Scandinavian countries, mainly in Sweden (Piippo, 2008; Cullberg et al., 2002). In international terms, a narrative review by Gromer (2012) covering seven NAA studies concluded that the outcomes were equivalent or superior to those of standard care. NAA was one of the approaches in the meta-analysis by Bola (2005), who found that an avoidance of neuroleptic medication in the initial phase of psychosis can have long-term advantages.

The development of NAA has involved a considerable amount of qualitative research. Seikkula (1991) studied the boundary system and the co-evolution between clients and professionals. He found that if the team regarded itself as a part of the problem, the family had a good opportunity to adapt their behavior. In addition to creating a dialogue the team should be able to find the family's way of using language from moment to moment (which is in contradiction with various highly structured therapy methods). Keränen (1992) found that the crucial factor influencing the choice between outpatient and inpatient treatment was the reciprocal interaction between the clients and the team. According to Lehtinen (1993) if continuity is lost, the professionals' work easily becomes treatment of the complications of the treatment. An important finding by Lehtinen - namely that psychiatrist should be extremely active in discussing medication in order to guarantee that patients will not lose their agency any more than is needed - was confirmed by Iso-Koivisto (2004). Haarakangas (1997) noted how challenging it was for inexperienced professionals to use their own emotional responses in engendering conversation; he also pointed to the usefulness of the team's internal reflective conversations. Vuokila-Oikkonen's (2002) study on acute inpatient care showed how important - but also how difficult it was for authoritarian participants to give space for the expressions of coworkers and clients within common meetings. A narrative study by Holma (1999) indicates the importance in acute psychosis of constructing a selfnarrative which will make psychotic "prenarrative" experiences meaningful for the patient, family members, and professionals: by this means a sense of agency is gained. In attempting to understand the patient through diagnostic stories in which personal meanings are not shared, there is a risk of driving the individuals into a vicious circle.

Prior to the present research, professionals' experiences of NAA have been discussed more explicitly only within the qualitative analysis of the Acute Psychosis - Integrated Treatment Project (Aaltonen et al., 2000). The analysis there showed the major importance of the treatment setting, the experiences of the staff, and the unequivocal support of management. In comparing good and poor outcomes, Seikkula (2002) noticed how important it was for clients to have dominance of the conversation, and for professionals to listen to the patient's self-reflections. Although in her interview study Iso-Koivisto (2004) gave different names to the two main narrative types of psychotic experiences (a paranoid- 
schizoid position mode and a depressive mode), they resemble the concepts of sealing over and integration (Geekie \& Read, 2009). Piippo (2008) found that familyand network-oriented treatment models based on NAA give more opportunities for clients to create trust and to experience safety than traditional approaches. Several of the above studies also support outpatient care as the preferred alternative to hospitalization (Haarakangas, 1997; Lehtinen, 1993; Seikkula, 1991).

\subsubsection{Recovery-oriented services}

Recovery can be defined as something that people experience and do by themselves, while gaining self-esteem and becoming empowered to manage their lives. The principles of recovery-oriented services emphasize the individual decisions and goals of service users. Both the professionals and the service users should be aware of the mutual negative impact of the dependency. A hopeful and trusting relationship is to be encouraged, and a holistic and integrative approach includes emotional and spiritual needs, in association with the strengths and abilities of users. A social network of users can be regarded as a possible resource for recovery, and it is important also to recognize the users' local and cultural context, and their values.

In contrast to a hierarchical model of services, a key component of recovery-oriented services is a collaborative relationship between users and professionals, highlighting the human rights and common humanity of all parties. Attention is paid to goals that take the person out of the sick role and allow him or her to give something to others - including the staff - contributing also nonmental resources and experts of experience. There is a need to recognize and value the significance of the small achievements of ordinary life. Work and other meaningful functions which connect individuals to the society around them have a major role in recovery. If professionals are able to be flexible and available, to respond as people, and to take positive risks in the therapeutic relationship, they may function as an important resource of hope for a patient who is struggling for recovery. Hope can and should be maintained in the face of failures and setbacks, which are important elements in learning and recovery.

The principles of recovery-oriented services include working with the symptoms, and trying to find a common understanding and negotiating stance concerning medication - aspects that challenge the normal practice of making medical notes and using objective language. Overall, a recovery orientation places an emphasis on the experiences and words of the users (Anthony, 1993; Anthony, Rogers, \& Farkas, 2003; Currie, 2011; Jacobson \& Greenley, 2001; Lester \& Gask, 2006; NIMHE, 2005; Roberts \& Wolfson, 2004; Topor, 2004).

Borg et al have pointed out (2009) that although many practitioners claim that their practice is already based on these values and principles, in most Western countries there seems to be a gap between the rhetoric and what continues to happen in the field. According to the authors, The Open-Dialogue Approach has managed to overcome the challenges standing in the way of recovery-oriented person-centered care. This could point the way to the further 
development of NAA, which may be promoted by a human rights perspective on psychosis, in conjunction with a powerful voice from users and from people with expertise based on experience.

\subsubsection{A critical review of the Finnish Current Care Guidelines on Schizo- phrenia}

The first evidence-based Current Care Guidelines on Schizophrenia (CCGS) were published in Finland in 2001. Since then there have been two updates, in 2008 and 2013 (Working group appointed by the Finnish Medical Society Duodecim and the Finnish Psychiatric Association, 2013). They emphasize medication, (family) psychoeducation, and cognitive behavioral therapy (CBT). In a paper published together with the first CCGS, Huttunen (2001) discussed the "illusion of exactness," pointing out that in the clinical treatment of psychosis there is an understandable desire to overcome uncertainty and other emotional and interactional challenges by following rigorous guidelines. However, this can actually exacerbate the problems one is trying to solve.

On the basis of such arguments, one can suggest that the principles of the Current Care Guidelines may need re-evaluation, for the sake of the clients, and to address the practical challenges faced by psychiatrists and other professionals. It is worth noting that, for example, the NICE Current Care guidelines (The Schizophrenia Update Guideline Development Group and National Collaborating Centre for Mental Health, 2010) place more emphasis on the multifaceted nature of psychosis. There also seem to be major contradictions between the principles of CCGS and those of NAA, which was the focus of this research. In the paragraphs below I shall present a critical evaluation of CCGS.

Scientific discussion has indicated a need to reconsider the role of antipsychotic medication - and indeed the entire biogenetic paradigm of psychiatry (Bracken et al., 2012; Harrow, Jobe, \& Faull, 2012; Lepping et al., 2011; Morrison et al., 2012; Priebe, Burns, \& Craig, 2013). This is not reflected in CCGS, with the updates moving rather in the opposite direction. However, a minor positive development (from the psychosocial perspective) can be seen in so far as in the two latest versions mention is made of the role of traumatic experiences as factors predisposing to psychosis.

The development of NAA was closely connected with Finnish national programs between 1981 and 1998 which were seeking to develop the treatment and rehabilitation of schizophrenic psychosis (see e.g. Aaltonen et al., 2000; Lääkintöhallitus, 1988). From the start, the impact of the NAA tradition on CCGS appears to have been minor, and it may even have diminished in later versions. Nevertheless both NAA and CCGS affirm the importance of a longterm confidential treatment relationship and of a regularly revised treatment plan which takes account of the individual needs of the patient and his/her social network. In addition, the recommendation to maintain hope runs parallel with NAA-related studies (Piippo, 2008). Despite this, CCGS advises practitioners to use the concept of schizophrenia, emphasizing also the bio-genetic approach - aspects which have been shown to increase pessimism (Read, Haslam, 
\& Magliano, 2013). Some prominent authors, including McGorry (2005), have taken account of the negative impacts of the concept of schizophrenia and of criticism concerning its scientific reliability and validity (Bentall, 2013; Read, 2013a). Hence, they have concluded that there is no need to formulate a diagnosis of schizophrenia with first-episode patients. Here, as an example of the variation in national choices, one can mention Japan, which has been the first country to abandon the term schizophrenia (van Os \& Kapur, 2009). Furthermore, for the sake of the crucial issue of maintaining hope, it might have been beneficial in CCGS to add some words on the recovery approach, and to give voice to service-users (see e.g. Anthony, Rogers, \& Farkas, 2003; Roberts \& Wolfson, 2004; Topor, 2004) - aspects which appear to be almost totally absent from the recommendations.

According to psychotherapy research (see e.g. Leiman, 2006; . Messer \& Wampold, 2002;, Norcross \& Wampold, 2011b), the benefits of therapy are based more on the relationship than on the technique or approach. From this point of view, the emphasis of CCGS on CBT and on family psychoeducation raises questions. Evidence-based medicine (EBM) is founded on randomized controlled trials (RCTs), with an emphasis on therapies in accordance with manuals. Such an emphasis may indeed cause more weight to be given to CBT and psychoeducation. However, according to Wampold and Bhati (2004), strict adherence to therapy manuals is harmful for the alliance, with consequent poorer outcomes.

In evidence-based medicine, efforts may be made to discover universal causal explanations through the use of RCTs within experimental quantitative studies. Such efforts may achieve high intrinsic validity (Wahlbeck, 2005). Nevertheless, while some problems may be solved in this way, other problems are likely to emerge. In the real-life setting of acute psychosis there are innumerable factors which cannot be controlled, and average values may not have any utility for individual instances (Seikkula \& Arnkil, 2005). One example of the gap between research and clinical reality involves psychoeducational family interventions. There has been convincing evidence of the effectiveness of such interventions since the start of the 1980s, yet they are still not available in Western countries (Berry, 2008; Fadden et al., 2005). A naturalistic research setting, which would exhibit more extrinsic validity, has been seen as one means of narrowing the gap between optimal treatment possibilities and the results achieved in everyday clinical settings (Kissling, 2001; Seikkula, 2005).

Louhiala and Hemilä (2005) stress that in all its steps the construction of the recommendations is based on continuing choices, grounded on values and preferences. The issues in question are highlighted when one compares the Finnish CCGS with the British NICE, and with the American PORT ${ }^{5}$ (Buchanan \& Keller, 2010; Dixon et al., 2010; Kreyenbuhl et al., 2010). Though all three emphasize antipsychotic medication, CBT, and family (psychoeducational) interventions, there are also substantial differences. The voices of the various stakeholders are given much more prominence in the NICE of Britain than in the

5 The acronym refers to the Schizophrenia Patient Outcomes Research Team. 
CCGS of Finland. Whereas the CCGS working group was composed merely of physicians, the NICE development group was truly multiprofessional, including also users and a carer. In NICE, declarations of interest are not given merely in respect of persons from the pharmaceutical industry; in fact, all declarations of interest are set out in detail. In this connection, it is interesting to note that $57 \%$ of the CCGS working group (as compared to $31 \%$ of the NICE group) made declarations of interest regarding connections with the pharmaceutical industry.

Unlike the CCGS perspective, the recovery approach is clearly visible in NICE, which includes a section on the experiences of users and carers. For its part, PORT takes account of the recovery approach in a separate article (Davidson, 2010).

Comparisons reveal further differences in emphasis. Thus, NICE contains an explicit description of the methodology used in the guidelines issued. The methodological aspects of CCGS are referred to merely in passing, with mention of the principles of evidence-based medicine and a general article on Finnish practice. NICE refers to scientific discussion of the concept of schizophrenia and the impact of receiving the diagnosis; this has been shown to be manifested as pessimism, and has further been shown by long-term follow-up studies to be negative in terms of outcomes. All in all, NICE seem to be more psychosocially oriented than CCGS, which emphasizes biogenetic issues.

The social constructivist nature of the process of making the recommendation is transparently described in PORT (Kreyenbuhl et al., 2010). Moreover, in PORT only those pharmacological treatments with at least one non-industrysponsored investigation are considered for recommendation status. NICE and PORT - but not CCGS - openly acknowledge the shortcomings of recommendations based on RCTs, with recognition also of the dilemma between internal and external validity. Compared to CCGS, PORT (Buchanan \& Keller, 2010) is clearly more critical of antipsychotic medication and other biological treatments. PORT questions the benefits of medication, considering psychosocial functioning, quality of life, and negative symptoms. It also contains reservations on adjunctive antidepressants, and further, on the use of ECT, which is not even mentioned in NICE.

CCGS is the only set of guidelines which opens up the possibility of using antipsychotic medication in prodromal symptoms. There are also contradictions between the psychosocial recommendations concerning social skills training, assertive community treatment (ACT), and cognitive remediation, even though the recommendations are partly based on the same recent meta-analysis. Differences in the recommendations concerning art and music therapies appear to reflect the attitudes of the members of the development groups rather than any transparent criteria.

Overall, one can argue that despite the rhetoric from various quarters which would tend to emphasize the accuracy and unambiguousness of natural science - manifesting, indeed, the "illusion of exactness" (Huttunen, 2001) - the guidelines in Finland and elsewhere seem in their essence to be socially constructed. According to Luborsky et al. (1999) even basically well-designed out- 
come studies are not free from the commitments of the researchers. This seems to hold very true with respect to the kinds of written recommendations mentioned above, which are full of choices made according to the preferences of those concerned.

\subsection{Inner dialogues}

The concept of an inner dialogue is by its nature peculiar. As human beings we have thoughts, emotions, perceptions, mental images, memories and other diverse internal experiences. They appear to be interdependent and to function in relation to each other in a way that might be termed inner dialogue or inner speech. On the other hand, from a more "objective" perspective, the concept is more theoretical in nature: although we might conclude, based for example on observations of our interlocuter's facial expressions, that there is something going on in her/his mind, at a given moment we verify and explore inner dialogues only by outer dialogue. The inner dialogue has plenty of wordless content, and furthermore, since it changes during the outer dialogue, we are unable to capture it. All in all, the inner dialogue appears to be enmeshed not just in the present outer dialogue but also in the entire (historical) context of the situation.

According to Archer (2003) internal dialogue as a phenomenon is the human practice of reflexivity, a practice in which we engage to talk ourselves out of being unsure. Based on sociological in-depth interviews, she concluded that there are a variety of individual forms of internal conversation, resulting in different kinds of social outcomes. In contrast to Archer's structural description, this research took a different stance on the phenomenon of inner dialogue, namely that of dialogism.

According to Markova et al. (2007) dialogism is a theoretical approach which emphasizes that humans live in the world of others, and that their existence, thoughts, and language are thoroughly interdependent with those of others. This way of understanding inner dialogue as an interdependent part of outer dialogue is largely related to the ideas of Mikhail Bakhtin (1981, 1984, 1986) and his co-workers. Volosinov (1990) highlights the complexity of inner speech, claiming that utterances are determined not only by the inner life of the speaker but also by the dialogical context. As we put our inner speech into words, it changes. Voice, positioning, and addressee are three concepts which are used to catch the complexity of dialogical phenomena. Voice refers to the speaker or actor, positioning to the position from which she/he is speaking or acting, and addressee to the person to whom one is speaking, or the person who is being acted upon. Depending on the context, every participant in a dialogue - even in a single utterance - speaks in different voices, positions her/himself in different ways, and addresses speech to one or several persons or audiences. The audience might also be absent, or not even concrete but rather ideological in nature. Utilizing Markova's (2006) conceptual triad, inner dialogue could be defined as 
discussion in our mind between the Ego (self) and the Inner Alter (someone else from the context of our life) concerning Objects or representations. One aspect of the inner dialogue is the presence of "the third party"; thus, when we are in an outer dialogue with someone, we do not merely address our words to our interlocutor but also to others who are not present. From the perspective of this research, Bakhtin's (1986) concept of super-addressees was important: the third party can also be some idea or ideology, such as God, absolute truth, the human conscience, or science. According to Markova (2006) inner dialogue constitutes a means to solve the author's conflict and to protect or enhance the interests of the Ego: the inner Alter takes different positions as a potential mediator between the Ego and a powerful third party. One specific aspect concerning the inner dialogue is self-dialogism (Markova et al., 2007): when listening to our own speech we can comment or transform our own discourse according to the internal dialogue aroused by our own voice.

The formulation of subjectivity by Salgados and Hermans (2005) illustrates nicely the interconnectedness and dialogical nature of inner and outer phenomena in human psychology. Using Bakhtin's (1984) studies on the polyphonic novel, they write about the polyphonic society of the mind and about the continuous dialogue and interplay between different I-positions. Their formulation emphasizes the intertwined process of selfhood and otherness. According to them, the relational contrast between the I and the Other or the audience is a fundamental element of subjectivity. The addressed audiences are a constitutional part of the self, which are like me (the ego) and, at the same time like another (the alter). The sense of being the same person, the subjective side of being an individual, is not a phenomenon embodying isolation; rather it is a matter of communication with others and with oneself. In a practical dialogue there is a simultaneous process of inner dialogues with other potential audiences, and all these dialogues have relevance for the matter under discussion.

\subsubsection{The professional's inner dialogue}

All professionals dealing with the phenomenon of psychosis are likely to have to operate on the basis of vertical as well as horizontal expertise (Laitila, 2004, 2009). In addition to classical expert knowledge, concerning issues such as psychiatric medications, psychiatrists need skills for interactive work, which is an ongoing process requiring self reflectivity. In order to take account of clients' views in shared decision making - and of the social context as a whole - the professional needs the ability to join the outer dialogue and simultaneously to be open to an inner dialogue of her/his own.

Family therapists have used a variety of concepts ${ }^{6}$ in trying to catch the phenomenon of the therapist's inner dialogue (Andersen, 1994; Anderson \& Goolishian, 1988; Penn \& Frankfurt, 1994: Rober, 2005; Seikkula, 2008). Rober (2005) describes inner conversation as a negotiation between the experiencing self and the professional self of the therapist, concerning the actions the thera-

6 Inner/internal conversation, talk, speech, dialogue, voices 
pist should take in the outer conversation. The experiencing self is involved in the experiencing process of the therapist as a human being, not just someone making observations, but someone with emotions and imagination. The professional self, on the other hand, observes the experiencing self. It tries to make sense of what is going on in the conversation and prepares responses to facilitate the therapist's professional task. An important challenge for the therapist's inner conversation is how to deal with difficult emotional responses - since professionals, too, can be hurt in the treatment processes - and to maintain genuine respect towards the clients. According to Rober, a therapeutic impasse could be welcomed as an opportunity. Another challenge for the inner dialogue of professionals is to maintain a true curiosity concerning the client's stories - to have a not-knowing position (Anderson \& Goolishian, 1988), or an ability to tolerate uncertainty (e.g. Seikkula \& Olson, 2003). Rober (2005) understands hypothesizing - a concept which is based on family therapeutic work by the group referred to as the "Milan team" (Cecchin, 1987; Selvini et al., 1980) - as a process in which there is continuous movement in the therapist's inner conversation back and forth between knowing and not knowing. Hypotheses can be constructive if professionals constantly pose questions to themselves regarding their truth status and their value for treatment co-operation and for the client.

The psychoanalytic approach speaks of therapists' counter transference, complementary affects, introspection, and self analysis (Tähkä, 1982). Though the (restricted) original meaning of these concepts is specifically connected to psychoanalytic theory, they do also seek to capture aspects of professionals' inner dialogues in therapeutic relationships. The emotions of therapists are also dependent on their own personal background; thus, according to Tähkä, therapists should pause to have an inner dialogue concerning their own responses, particularly if the treatment is not proceeding as expected. In NAA therapy meetings, professionals have to consider whether their emotions and associations are in any way connected to the treatment, and whether it might be useful to utter them aloud.

The concept of a shared image guiding the treatment process was established in a study by Aaltonen and Räkköläinen (1994) which aimed to develop psychotherapeutic in-patient treatment for acute psychosis according to the principles of NAA. All the staff members of a multiprofessional team, including the hospital cleaners, attended supervision sessions. Because each member of the staff brought her/his own experiences of the treatments into team discussions, it was possible to integrate both the symbolic and the non-symbolic behavior and symptoms of the patients in such a way as to achieve a shared understanding. Each participant in the meeting participated in the discussion (the outer dialogue) and at the same time had many thoughts about what was discussed (the inner dialogue). Berry and Wearden (2009) found that by helping staff to modify their perceptions and to develop psychological formulations concerning individual patients, their feelings of agency, respect, and optimism towards psychotic patients seemed to increase. 
In order to gain a more complete picture of the research on professional inner dialogues, I conducted literature searches using words that appeared to represent emotional and cognitive processes ${ }^{7}$. Thus, early in 2011, I identified almost 200 papers covering different professions. To give some examples, the papers on physicians dealt with topics such as information processing during medical interviews (Cegala et al., 1995; Saba et al., 2006), shared decision making ( Elwyn \& Grol, 2000; Saba et al., 2006), clinicians' perspectives on clinical guidelines and evidence based treatment (Rees \& Harrison, 2002), the pharmaceutical industry (Wazana, 2000), and ethical questions (Torjuul, Nordam, \& Sorlie, 2005). A study by Henriksen and Hansen (2004) showed the importance of emotions in the inner dialogues of professionals, even within everyday medical practice.

As regards psychosis, the studies on professional inner dialogues during treatment dealt with, for example, compulsory treatment measures (MarangosFrost \& Wells, 2000; Wynn, 2003), clinicians' thoughts on antipsychotic medication (Barley \& Harrison, 2008), perceptions of early interventions (Galeazzi \& Rigatelli, 2006), expressed emotions (Berry, Barrowclough, \& Haddock, 2011), and the stigmatizing attitudes of staff (Rao \& Luty, 2009). Holmqvist studied professionals' feelings in relation to patients' diagnoses (Holmqvist, 1998), and treatment outcome (Holmqvist \& Armelius, 2006), while Berry and Wearden (2008) studied staff attachment styles. Oud et al. $(2007,2009)$ studied GPs'́ experiences of providing care to their psychotic patients.

Several studies have compared the views of professionals, clients, and the general public on various issues relating to psychosis: for example experiences of violence in psychiatric care (Omérov \& Wistedt, 2004), and perceptions of the needs of patients (Macpherson \& Lerescu, 2008; Macpherson \& Slade, 2003) and of carers (Askey \& Gray, 2009); also perspectives on early psychosis services (Langlands \& Kitchener, 2008) and recovery (Noiseux et al., 2010).

\subsubsection{Therapeutic relationships in a multi-agent treatment setting}

NAA is based strongly on the therapeutic relationships between clients and professionals, whose inner dialogue is an important part of the whole. Psychotherapy research has shown fairly convincingly that in addition to extratherapeutic factors, common factors (as they have been called) such as empathy, warmth, and the client-perceived therapeutic alliance have the closest relationship with the outcome, regardless of the diagnosis (e.g. Lambert, 2005; Lambert \& Barley, 2002; Messer \& Wampold, 2002; Wampold, 2005; Wampold \& Bhati, 2004). The findings that psychotherapy should be tailored to the specific client (Norcross \& Wampold, 2011a, 2011b) rather than manualized (Messer \& Wampold, 2002; Wampold \& Brown, 2005) and that the relationship should be evaluated frequently (Lambert \& Barley, 2002) run parallel with the NAA principle

$7 \quad$ In addition to the concepts and terms mentioned in this section I applied the terms thought, emotion, feeling, perspective, perception, view, attitude, insight, self talk, cognitive process, introspection, challenge, and intention. 
of having more or less open discussions in therapy meetings, with efforts to target the treatment to the changing needs of the clients. Most psychotherapy research indicating the importance of the therapeutic relationship has been connected to individual therapy or counseling. NAA, on the other hand, is more of a family therapeutic approach integrating different treatment methods undertaken by a multiprofessional team. Nevertheless, research from family and couple therapy also gives support to the importance of common factors in the therapy outcome (Sprenkle, Davis, \& Lebow, 2009).

Although one might think that the relationship is even more important in severe disorders such as psychosis, those studies which have highlighted the common factors in psychotherapy do not (to my knowledge) involve psychotic disorders. However, as early as 1990, a study by Frank and Gunderson (1990) indicated that a good therapeutic alliance was associated with a better outcome among nonchronic schizophrenia patients. Indeed, one can say that even a quarter of a century ago attention was paid to the importance of evaluating the alliance and the need to identify contributing factors. There is also some newer research indicating that a more positive therapeutic relationship predicts better outcomes from severe mental disorders (McCabe \& Priebe, 2004: Priebe et al., 2011).

An additional crucial element in NAA is the relationships among the staff. Several authors (Egan \& Jaye, 2009; McGrail \& Gardner, 2009; Safran \& Beckman, 2006) have emphasized that whereas in clinical schools education is mainly structured around individuals, clinical practice mainly involves relationshipcentered teamwork. The concept of relationship-centered care (RCC) (Beach \& Inui, 2006; Safran \& Beckman, 2006; Suchman, 2006a, 2006b) has been used to recognize the importance of relationships for health outcomes, encompassing the personhood and emotions of all the participants and the context of reciprocal influence. RCC emphasizes that clinicians ought to listen to and respect colleagues; thus, instead of medical control, it focuses on interpersonal processes, trust, and partnership. NAA can, with good reason, be viewed as one model of relationship-centered care.

Although medical errors are largely a result of failed communication among clinical teams, at least up to 2006 little research had been conducted on clinicians' colleague relationships (Safran \& Beckman, 2006). I found only a couple of studies on teamwork with relevance to the present research. Onyett and Muijen (1997) found that burnout among members of community mental health teams was associated with team relationships. Peck and Norman (Norman \& Peck, 1999; Peck \& Norman, 1999) discovered that psychiatrists experienced a heavy load of expectations from other professionals, and that they tried to minimize blame through over-control of patients. For his part, Griffiths (2001) noticed that the autonomy of team members tended to marginalize psychiatrists and to dilute individual responsibility. The only study I found on teamwork in psychosis (Engqvist \& Nilsson, 2010) concluded that collaboration between nurses and the psychiatrist in postpartum psychosis is based on confidence in the nurses' competence. Interestingly, there seemed to be more in-depth studies 
on team communication in other fields of medicine. Thus, for example, it was found that in operating rooms the patterns of communication were complex, socially motivated, and tensioned (Lingard \& DeVito, 2002). Research had also been conducted on the crucial components of physicians' respect for nurses (Rosenstein, 2002; Schmalenberg \& Rapp, 2005), the importance of interprofessional collaboration for novices ( Lingard \& Espin, 2002; McGrail \& Gardner, 2009), and the major impact of boundaries in health care organizations (Braithwaite, 2010).

The reflective practice of expertise, described by Schön (1983), sheds light on the multi-agent professional practice of NAA. When the situation is complex and uncertain, and when there are many competing views, discussion between professionals and with clients is needed, as much to identify the problem as to solve it. According to Schön, our knowing is normally tacit within our actions. In NAA therapy meetings this implicit knowing-in-action of all the participants is available for reflection, and professionals become researchers in the context of practice. Professionals, in fact, construct a new theory for a unique case by shaping a situation in which "back-talk" is listened to, appreciated, reframed, and responded to. The unique situation of a therapy meeting - which includes several participants with several voices - comes to be understood through attempts to change it, and it is changed through attempts to understand it. An extremely important element in this kind of reflective practice is the professionals' inner dialogues concerning their own contribution, and their readiness to discover the limits of their expertise.

Bateson $(1980 ; 1985)$ is an anthropologist who has had a major influence in the family therapy field since the 1960s. He has emphasized the primacy of relationships and of circular causality. In Bateson's way of thinking, the mind is not something within a human, existing rather in an entire relational context of movements, with evolving ideas and information exchange. According to the phenomenological approach of Fuchs and De Jaegher (De Jaegher, Di Paolo, \& Gallagher, 2010; De Jaegher \& Froese, 2009; Fuchs, 2002; Fuchs \& De Jaegher, 2009), social understanding can be seen as an ongoing, dynamic process in which the lived bodies of participants form a common incorporality, through a constant coordination and mutual coupling of two embodied agents. Evidence of the role of social interaction is seen in the development of mirror neurons, indicating that the body works as a "felt mirror" of the other. From this point of view, in the process of sense-making, the participants and the interaction process have some autonomy of their own. In a similar manner, the systemic view of Bateson and the phenomenological view of Fuchs and De Jaegher highlight the co-dependence between the inner dialogue and context; thus, in a social situation we have only limited control even over ourselves, let alone the total situation. The authors of the books edited by McNamee and Gergen (1999) have introduced a concept of relational responsibility, seeking thus to capture the phenomenon of responsibility in human interactions. 


\subsubsection{Professional agency}

A sense of agency can be seen as a part of the inner dialogue of professionals, and one that has an impact on the therapeutic relationship. According to Fuchs (2005), agency is based on a bodily sense of potentiality, on being able to move, and on the actual proprioceptive and kinesthetic sensations of movement. In social constructionist literature the concept of agency is defined as the capacity to make choices and to act upon them (Burr, 2004). In the treatment processes of psychosis, which are heavily regulated by laws and other social norms, the agency of psychiatrists is perhaps located at the interface between micro and macro versions of social constructionism. According to Burr, the former affords personal agency, in contrast to the macro approach, which perceives subjects only as the outcome of discursive and societal structures resulting mainly from "Foucauldian" phenomena of power. On the other hand, our choices are delimited not merely by explicit social norms (and the implicit ones present in discourse) but also by our mutual incorporation (De Jaegher \& Froese, 2009; Fuchs, 2005; Fuchs \& De Jaegher, 2009) in conversation. In a therapy meeting the personal agency of professionals can be seen to rest on their inner dialogue, concerning how to response explicitly, and involving for example how to open up marginalized and repressed discourses. This again depends on clients' possibilities to change their behavior or their ways of thinking. Using the concept of the zone of proximal development (ZPD) ${ }^{8}$ (Vygotsky, 1978, 1982), Leiman and Stiles (2001) (among others) have proposed that in order to work, therapeutic interventions must be within the client's ZPD of assimilation.

The concept of double agency or of a dual role (e.g. Robertson \& Walter, 2008), as used in psychiatric literature, refers to psychiatrists' conflicting obligations to their patients and to a powerful third party. This is an ethical dilemma which can cause psychiatrists to reduce risks instead of alleviating suffering. All mental health professionals have been found to perceive conflicting requests coming from users, the local community, and institutions. Certain aspects, in particular the social control function, but also economic agendas and the biomedical dominance of psychiatry, are related to job satisfaction and are felt to constrain therapeutic freedom (Galeazzi, Mackinnon, \& Curci, 2007; Rosen, 2006). Berry and Wearden (2009) found that among staff, feelings of agency towards psychotic patients seemed to increase when they were helped to develop psychological formulations concerning individual patients. In a study on inpatient mental health wards, Totman et al (2011) identified various factors that had positive influences on staff morale, which is an important part of agency. These included good relationships with colleagues, a culture of openness and acceptance, informal support from managers, spending time with patients, and seeing them get better. According to Rosen (2006), major challenges to agency among community psychiatrists derived from experiences of unrealistic expec-

8 The developmental psychologist Vygotsky defined the ZPD as the distance between a child's actual developmental level of independent problem solving and the level of potential development, as determined through problem solving under adult guidance. 
tations, loneliness, and a role involving the containing of difficult team emotions. Austin (2008) found that psychiatrists struggled to come to terms with their genuine selves in their professional roles. As agents for society their actions tended to become agent-less, and they themselves became "artificial persons."

Some studies on shared decision making (SDM) have shed light on the complexity of psychiatrists' agency in the treatment of psychosis. Psychiatrists have been observed to have difficulties in responding to patients' active attempts to talk about the content of their psychotic symptoms (McCabe et al., 2002). They also appear to be willing to use strategic dishonesty in consultations involving anti-psychotic medication, and to reject patients' reports of sideeffects from medication (Seale et al., 2007). On the other hand, they may attempt to emphasize a human rather than a purely professional response (Seale et al., 2006), and try to protect the face of patients by avoiding pressurizing them into making choices on antipsychotic medication which they clearly do not want (Quirk et al., 2012).

Overall, Seale et al. (2006) found that patient-centered practice was bound up with emotional labor among psychiatrists, concerning for example questions of the competence of the patients. In addition, they found that organizational factors obliged psychiatrists to rely on medication rather than alternative methods. The central challenge to psychiatrists' professional agency appears to be how to adapt their communicative styles to the differing contexts of service users (Quirk et al., 2012).

\subsection{Aims of the research}

The main aim of the research reported here was to describe the nature of the inner dialogue of psychiatrists during the treatment processes of psychosis, in the context of the Need-Adapted Approach, in other words, while co-operating with the patient, her/his social network, and other professionals. In addition, the research sought to describe how the embodied experiences of professionals may have an impact on the treatments given. As a third goal, the research aimed to arrive at some tentative principles or guidelines on how to study the phenomenon of professionals' inner dialogues.

The research was comprised of three studies. Study I focused on describing the psychiatrist's inner dialogues concerning workmates. Study II focused on how the psychiatrists in the study saw their agency. Study III focused on the impact of psychosis on the treatment, the psychiatrists, and other professionals. 


\section{METHODOLOGY}

To serve the descriptive orientation of the research, I chose a qualitative multiple case study approach using videotaped biphasic interviews. The research questions for the three studies, which were all based on the same basic data, were modified in the light of the interview material, the overall intention being to gain a better understanding of the inner dialogues of psychiatrists within the psychosis treatment process, in the context of NAA. Hence, the analytical methods of the three studies differed from each other.

\subsection{Participants}

Five different clinics from three different geographical areas in Finland agreed to take part in the research. These clinics had either some tradition of NAA or were in some other way specialized in the treatment of first-episode psychosis, including co-operation with families. The staff themselves indicated their willingness to take part. It was they who chose the patients and invited them for the interviews, accompanied by their family members. In addition to written informed consent, the only inclusion criterion was that the patient should have been treated for a schizophrenic psychosis (ICD-10 diagnosis F20-29) for a maximum of two years. The first eight treatment processes that became available were included in the research.

Eight psychiatrists aged 36-61 years took part in the research. Seven were females and one was a male. Six had lengthy experience in psychiatry, four of them were family therapists, and two were undergoing their psychiatric training. The participants' experience of psychotic patients ranged from one to 26 years. Three of the psychiatrists were in charge only of patients' inpatient care, while two were responsible for outpatient care, but also contributed to inpatient care. The remaining three psychiatrists worked purely in outpatient care. In two interviews the psychiatrists from both the inpatient and outpatient care centers were present. Two psychiatrists were interviewed twice. As the purpose was to 
study psychiatrists' inner dialogues in individual treatment processes connected to individual patients, in this sense one could say that ten psychiatrists (in their capacities as conductors of separate processes) were interviewed. In seven interviews only one co-worker was present, while in the eighth there were three. Eight of the participating co-workers were nurses, and two were psychologists. The patients, who were aged 19-56 years, consisted of four females and four males. On four occasions the patient's mother took part in the interview, on two occasions the mother took part together with a sister, and on one occasion a sister took part. One patient did not want his family to contribute to the treatment, and this patient's family was not interviewed. All the interviewees were asked for their informed consent. The interviews were conducted between August 2007 and January 2009.

\subsection{Interview methods}

I myself conducted the videotaped biphasic interviews using two different methods. To create an NAA context in which the inner dialogue could be studied, the psychiatrists were first interviewed together with the patient, family members, and fellow workers within the team, applying the co-research interview method (CR-I) (Andersen, 1997). CR-I is a method which allows the professionals and the clients to evaluate the treatment process, its successes and its failures, conjointly with the help of a third party. The interview, which in this research was conducted twice after termination of the treatment and six times in the middle of the treatment processes, separates talking and listening: thus, first the professionals and then the clients were asked to evaluate the treatment process, with the other parties listening in each case. The CR-Is ended in an open discussion. Although the main purpose of the final section is to evaluate the experience of the interview, the participants occasionally continued to talk about some issues pertaining to the actual treatment. With the exception of the first pilot interview ${ }^{9}$, I conducted a brief inquiry (five times by phone and three times by e-mail) with the psychiatrists, after the CR-Is, but on the same day. The purpose was to discover those CR-I issues about which the psychiatrists, during the interview or afterwards, found themselves having an inner dialogue.

On the basis of what the psychiatrists told me in the post-CR-I inquiry, I searched for the segments of the videotapes which included the issues mentioned. The purpose now was that I and the psychiatrist would watch these segments in the course of a stimulated-recall interview (STR-I). This was done to help the psychiatrists to recall their thoughts and feelings during the earlier interviews with the patients. The STR-I was conducted individually, or in pairs in

9 In the pilot interview, I as the researcher chose the CR-I video segments for the STR-I, based on the various treatment aspects of described in the introduction. As it resembled considerably the other interviews (the psychiatrist to be interviewed primarily talked about issues, which had occupied her/his mind after the CR-I) it was taken along to the research. 
the case of two interviews in which psychiatrists from both in- and outpatient care were present. They took place according to the timetables of the psychiatrists, i.e. five interviews were conducted one day after the CR-I, one was conducted two days after the CR-I, and two were conducted five days after the CRI. Both interviews (CR-I and STR-I) lasted approximately 1.5 hours.

CR-I has been used to study couple therapy in depression (Rautiainen, 2010), and individual treatment processes in psychosis (Blomberg, Rautkallio, \& Uusitalo, 1998); also to develop family therapeutically oriented therapy meetings, for example in the treatment of psychosis (Borgengren, 2006). Whereas CR-I is a rare interview method in research, STR-I is more widespread (Jokinen \& Pelkonen, 1996). In addition to studying professionals' inner talk in psychotherapy and counseling (see e.g. Elliott, Slatick, \& Urman, 2001; Kagan, 1969; Morran, Kurpius, \& Brack, 1989; Rober \& De Corte, 2008), STR-I has been used, for example, to examine the differences in doctors' and patients' experiences during medical interviews (Cegala et al., 1995).

\subsection{The analytical processes}

Each STR-I, including the segment of the CR-I watched from the video, was transcribed verbatim. I then viewed the videotapes several times, and at the same time read the transcriptions. Thereafter, I divided the transcriptions into topical episodes (Linell, 1998). In total, 139 topical episodes - most of which consisted of a discussion based on one episode of a CR-I - were formed. To categorize the material, I made summaries of the topical episodes. I observed that the interviewees spoke about (i) persons who were involved in the treatment process; (ii) the psychiatric syndromes and the symptoms; (iii) the treatment and opinions or stances concerning the therapies; (iv) institutional factors; and (v) the research situation. I chose the more specific research questions for the three separate studies (and thus also the analytical methods) one by one, after I had gained an overall picture of the data.

In Studies I and II I used an adaption of dialogical or dialogical-narrative analysis (Markova et al., 2007; Rober, Seikkula, \& Laitila, 2010; Wortham, 2001). As the workmates seemed to have an important impact on the inner dialogue of the psychiatrists, in Study I I paid particular attention to topical episodes in which the interviewees referred to their workmates. After searching through all the voices and positionings from psychiatrists' speech, I divided them into categories. I used these to write the results as a story describing the impacts of professionals' interrelationships on the treatment of psychosis.

In Study II the focus was on episodes dealing with psychiatrists' agency. The analytical concepts of voice and positioning plus an adapted version of the addressee were utilized to describe how the psychiatrists in their own narratives saw their agency, and what their ways of using words indicated about their positioning towards agency. 
In Study III I applied qualitative content analysis (Graneheim \& Lundman, 2004) to thematic episodes which exhibited some of the special features of psychosis, or some kind of change in the interview process (for example the psychiatrists starting to see the patients as healthier than before, or the emergence of new ideas concerning the treatment). In so doing I aimed to describe the impact of psychosis on the professionals and on the treatments. As the interviews were, quite literally, inter-views, involving a dialogical conversation on themes of mutual interest (Kvale, 1996), the voice of the interviewer formed part of the material for the third analysis.

All the main decisions concerning the interviews and analysis during the entire research process were discussed at least four times per year during group meetings supervised by the second author of the original papers. The more detailed assessment of trustworthiness is described in each of the original articles. 


\section{OVERVIEW OF THE ORIGINAL STUDIES}

\subsection{Study I}

\section{Psychiatrists' inner dialogues concerning workmates during Need Adapted treatment of psychosis}

The aim of the study was first of all to give a general description of the inner dialogues psychiatrists might have during Need Adapted treatment of psychosis. The material as a whole revealed the impact of workmates on the inner dialogues of psychiatrists. The interviewees spoke about their workmates in 60 of the 139 thematic episodes. The material was analyzed using an adapted form of dialogical analysis, and concepts of voice and positioning were used to categorize the material. Thereafter, the results were presented as a story, within which the personal aspects of the psychiatrists' inner dialogue related to their workmates affected treatment. ${ }^{10}$

Teamwork was seen as a self-evident aspect of the treatment of psychosis, and psychiatrists' discussions with experienced workmates were recognized as important ways to share responsibility. Nevertheless, the speech of the psychiatrists concerning their workmates mainly related to challenges and problems. Psychiatrists took action in the treatment situation not only as professionals, but also as individuals with their own - possibly troublesome - characteristics and emotional reactions as well as genuine relationships with their co-workers. It happened fairly frequently that the psychiatrists acted not merely with the responses of their clients in mind, but also those of their co-workers. It was also observable that if they had learned to trust a professional who was criticized by another participant in the CR-I, they found it difficult to accept that judgment. Threats or other major emotional challenges concerning the treatment had a tendency to turn into arguments between the professionals. Furthermore, the critical comments or demands of family members occasionally resulted in open

10 Utterances by the interviewers were quoted in eighteen extracts, and eleven of these utterances were used as headings in the Results section. 
disagreement between professionals. On the other hand, such occurrences could sometimes lead to a kind of unification of the professionals, involving the risk that the patient could be left on his/her own between the professionals and the family members. From time to time, institutional aspects, such as the boundaries between organizations and matters of medical responsibility (which was borne by the psychiatrists also in respect of their co-workers' actions), complicated co-operation between the professionals, or led to emotional difficulties, such as feelings of loneliness. Interprofessional collaboration was crucially important for inexperienced psychiatrists. Respect for the competence of workmates emerged as essential. This aspect sometimes made it difficult for the psychiatrists to voice critical views concerning their co-workers.

\subsection{Study II}

\section{Psychosis, Need Adapted treatment, and psychiatrists' agency}

In NAA the psychiatrist should be able to listen to and consider all the voices present in the therapy meeting, including the scientific and institutional voices of the profession, and to make choices and act upon them. The obvious challenges bound up with this were studied in order to gain a detailed understanding of how the psychiatrists (within their own narratives) saw their agency, and what their ways of using words indicated about their positioning towards agency. Adapted form of dialogical analysis using concepts voice, addressee and positioning were used to describe the data, and material that appeared to have clinical relevance was presented.

All the interviewees felt that they had made and acted upon relevant choices, but they also reported instances they could have handled better. There were clear difficulties in following the principles of NAA, and all the psychiatrists had experiences of losing their agency. One of the main challenges involved the strength of institutional forces. Occasionally, the psychiatrists lost their own professional voices and their actions became agent-less, which was experienced as morally disturbing. This resulted partly from the explicit demands of the social control function, but also implicitly from psychiatric discourse, which has a tendency to focus on pathology and to ignore human characteristics and experiences. In addition, strong emotions threatened the psychiatrists' feeling of agency.

The interviewees appeared to utilize the interviews as a form of clinical supervision. They searched for words to describe their emotions and confusing experiences, and they co-constructed a coherent narrative. They also evaluated their actions, and those who had an ongoing therapeutic relationship with the clients planned changes to the treatments. The most important choices involved the parts of the inner dialogue that it was useful to utter aloud, and the words and therapeutic orientations that were appropriate. In the best case, the psychiatrists were able to have inner dialogues that incorporated ways of increasing 
hope and empowering the clients. On the other hand, achieving a coherent narrative to calm down a disturbing inner dialogue was so important that occasionally it resulted in moralistic assessments of the clients, or the overlooking of actual facts. Critical views of the clients often ended up in positions of simultaneous self-defense and self-criticism. Discussion with trustworthy co-workers, previous experiences with psychosis, and positive feedback from clients were experienced as contributing to agency.

The institutional forces were particularly powerful in the inpatient setting, which tends to exaggerate risks, and which hinders recovery through its avoidance of essential uncertainty. Among the professionals in psychiatric hospitals there were tendencies towards a suppression of creativity, a reduction of hope, and frustration. On the other hand, the psychiatrists in the outpatient setting sometimes avoided delicate but important matters because they were afraid that the patients would leave care.

The psychiatrists working solely in the outpatient setting had a consultancy role which emphasized the stance of medical psychiatry; nevertheless, as members of case-specific teams they had indirect agency - mainly in terms of supporting nurses - concerning alternative methods of treatment. Psychiatrists who attended both in- and outpatient treatments had diverse personal contacts with the clients, and this actually compelled them to have an emotionally rich inner dialogue concerning the entire context, and to find ways of collaborating with the clients. This challenging arrangement required professional experience and training, but also a readiness to be exposed to strong emotions, plus a willingness to constantly learn from the clients. On the other hand, becoming too closely connected with the clients could occasionally pose a threat to the professionals' agency.

\subsection{Study III}

The Need Adapted Approach in psychosis: The impact of psychosis on the treatment, and professionals

There are many challenges associated with specific features of the psychosis phenomenon - features that often lead to difficulties in treatment collaboration and to efforts to control patients' psychotic symptoms through medication. It is also the case that society deals with psychosis very differently from most other health problems, in particular by accepting compulsory treatment. NAA is founded not on the immediate control of psychotic symptoms, but rather on the emergence of a dialogue between the patients and other participants within therapy meetings. Many of the universal issues arising in all relational practices are exceptionally visible in NAA. The study sought to analyze the experiences of professionals, seeking mainly to clarify the impact of the phenomenon of psychosis on the professionals and on the treatment processes. Closer examination was made of thematic episodes exhibiting some of the special features of psychosis, or some kind of change occurring within the interview process. 
Eighty-one of the 139 thematic episodes involved psychosis. In 71 of the episodes dealing with psychosis it was possible to identify some kind of clinically meaningful change within the interviews. The material was analyzed using qualitative content analysis. The discussion of psychosis dealt with the beginning of the treatment, psychotic symptoms, neuroleptic medication, involuntary acts, the setting of the treatment, the diagnosis, the family, and ethical issues other than compulsory treatments.

There were significant difficulties at the beginning of the treatment in all but one of the cases. In six cases these difficulties resulted in hospital care, three involving care of a compulsory nature; this had a tendency to complicate the situation even more. If the clients felt mistreated at the start, it could be difficult to focus on issues which might form the background of the psychotic crisis in the first place. This could result also from the staff becoming too cautious and avoiding emotionally challenging issues.

In the inpatient setting in particular, the professionals ran the risk of concentrating on symptoms and of interpreting patients' speech and behavior as psychotic even when this was not the case. As a result patients had the difficult task of convincing the professionals of their health and competence. It was extremely hard, especially for inexperienced psychiatrists, to tolerate the uncertainty bound up with the cases. In the CR-Is the psychiatrists were able to see the patients as healthier than during the actual treatment. It should be noted that antipsychotic medication had been used in all the eight cases, and that it had been seen as a self-evident treatment for psychotic symptoms by some persons with an important role in the treatment process. The case-specific differences concerning medication and the experiences of the patients were acknowledged, but tended to be overlooked in everyday clinical work.

Involuntary committal to inpatient treatment was experienced as traumatic by the patients and their families. It was almost impossible to proceed in a cooperative manner until the painful memories of coercion had somehow been addressed. The professionals' experiences of coercive measures varied greatly. Some of them felt the episodes to be so threatening that they were unable to continue the treatment with a specific patient, while others, by contrast, found it extremely important to carry on and discuss the issue with the clients (i.e. the patients and their families).

Although outpatient care was generally regarded as the primary setting, it often failed, despite serious attempts to make it work. The professionals experienced more problems in the inpatient setting, yet some patients did obtain benefit from being in the hospital. Occasionally, outpatient treatment, too, led professionals in the direction of over-caution.

Various other diverse findings emerged: the psychiatrists had different viewpoints on diagnostic categorization, but they tended to avoid the diagnosis of schizophrenia. Family members were seen as resources for the treatment. Their personal needs as clients had a minor role. The concurrence of parenthood and psychosis constituted a particularly complicated dilemma. In 
addition to coercive measures the psychiatrists were faced with a variety of crucial ethical questions in their everyday work with psychosis. 


\section{DISCUSSION}

\subsection{Main findings}

The research aimed to explore the inner dialogue of psychiatrists in the treatment processes of psychosis, in the context of therapy meetings following the NAA tradition. This approach involves co-operation with the patient, with her/his social network, and with other professionals. From the point of view of real-world clinical practice, the most important findings were as follows:

(i) When psychiatrists interact with the clients and other professionals, they respond as embodied individual human beings with possibly strong emotions. This indicates that the experiences and inner dialogues of the participants can be interdependent.

(ii) Clinician-clinician relationships can be of crucial importance in the treatment.

(iii) Especially in the inpatient setting, institutional forces can have an enormous impact on psychiatrists' agency, by reducing professional creativity and occasionally leading to a kind of agent-less experience.

(iv) Psychiatrists seemed to be more or less aware of the many harmful effects of (in particular) inpatient treatment.

(v) The interview methods used in the research increased professionals' reflective opportunities. They may be helpful in the dilemmas professionals encounter in practice.

Various aspects of the phenomenon of psychosis, including in particular serious ethical dilemmas, aroused difficult emotions both in the clients and in the professionals. Challenging situations tended to provoke criticism on the part of clients, co-workers, or the psychiatrists themselves; this again intensified the emotional stress of the psychiatrists, with threats to their sense of agency. It was difficult to follow the principles of NAA, especially for inexperienced psychiatrists, who needed support from their more experienced co-workers. 
In the psychiatric hospitals patients were easily seen purely as an illness, and the staff ran a major risk of becoming accustomed to procedures that reached the point of inhumanity. If the clients had experienced coercive measures, disrespect, or injustice, these issues had to be addressed if treatment was to proceed.

On the whole, outpatient treatments were experienced more positively by all parties. However, some patients benefited from (for example) the support of peers in the hospital, and occasionally psychiatrists felt that they had been too cautious in discussing vital issues in the outpatient setting. Psychiatrists who attended both outpatient and hospital care appeared to be the most capable of following the NAA principles, although this was extremely challenging, requiring strong personal commitment to the humanistic stance of NAA. It compelled the psychiatrists to experience more comprehensively the phenomenon of psychosis, including the disadvantages of the treatments. On the other hand there seemed to be no universal optimal way to organize the roles of psychiatrists, as this aspect was dependent on numerous local issues. The results indeed suggest that more use could be made of the knowledge and experience of staff to organize services at the local level.

The institutional forces that had a major impact were present not just in the regulations concerning the treatment, but also in the language used concerning the phenomenon of psychosis. The psychiatrists in this research mainly avoided giving a diagnosis of schizophrenia and some of them were aware of the unfavorable impacts of the concept. The results indicate that in order to adapt their dialogical potentials to the different contexts in which clients are met, individual psychiatrists should have more agency in the language they use in their practice.

\subsection{General discussion}

All the studies conducted for this research indicated that in the real-world situation of the treatment of psychosis, psychiatrists acted as deeply emotional individual human beings. They seemed to be compelled to take account of their embodied responses in the clinical context of their relationships with clients and co-workers, with local institutional issues, and with broader social, economic, and ethical issues. All of these are of major importance in the phenomenon of psychosis. From this point of view it is surprising that there are so few papers dealing in any depth with the human experiences of professionals treating psychosis. With a few exceptions (Austin, 2008; Engqvist \& Nilsson, 2009; Hardcastle et al., 2007; Robertson \& Walter, 2008), even in the writings focused on psychological and social approaches to psychosis (Geekie \& Read, 2009; Read \& Dillon, 2013), the accounts of professionals' perspectives have tended to ignore the human embodied emotional experiences of those concerned. Within the NAA approach, other studies (Aaltonen et al., 2000; Haarakangas, 1997; Seikkula, 2002) have indicated that we need to take into account the experiences of the 
staff. However, the present research is the first to focus specifically on professionals and their experiences.

Probably because teamwork in the treatment of psychosis was seen as selfevident, the psychiatrists in this research seldom mentioned its benefits. The interview protocol had a tendency to develop into a critical evaluation of the (mostly troublesome) treatments. The challenges and problems concerning workmates were one of the major issues in the interviews. They resulted not just from the challenges bound up with the treatments, but also from institutional aspects, and from more personal or even private issues in professional or clinician-clinician relationships.

Various fields of medicine have given rise to research with parallel findings, including the crucial role of teams in clinical work (Engqvist \& Nilsson, 2010; Jimmieson \& Gallagher, 2010; Vuokila-Oikkonen, 2002), the importance of interprofessional collaboration for novices (McGrail \& Gardner, 2009), the major importance of boundaries in health care organizations (Braithwaite, 2010), and the contradictions relating to a uni-professional culture, teamwork, and responsibility ( Herrman, 2002; Norman \& Peck, 1999; Peck \& Norman, 1999). The results of the present research indicate that the concept of relationship-centered care (RCC) (Beach \& Inui, 2006; Safran \& Beckman, 2006; Suchman, 2006b), which has mainly been used in general and somatic medicine, could be utilized also in psychiatry and in the treatment of psychosis. RCC stresses partnership, careful attention to all relational processes, shared decision-making, and selfawareness - principles which have much common with those of NAA. In fact, it is easy to agree with those authors (Egan \& Jaye, 2009; McGrail \& Gardner, 2009; Safran \& Beckman, 2006) who have pointed out the paradox between traditional clinical education (structured around individuals) and clinical practice (which is based on teamwork and relationships).

This research also shows parallels with the views of those authors who have noted the unrealistic expectations attached to psychiatric expertise (Austin, 2008; Rosen, 2006), and who have called for a reframing of the concept of responsibility in a more relational way (McNamee \& Gergen, 1999). In the NAA tradition there have been several ideas for utilizing and developing teamwork. One aim is to help staff to make choices that are more oriented to the clients' stories; this would be facilitated by the concept of a shared image guiding the treatment process (Aaltonen \& Räkköläinen, 1994), based on conversations between the (hospital) staff and a supervisor. Reflective discussion between team members in therapy meetings is a working method by which the personal voices of staff can become material for the inner reflection of the clients (Haarakangas, 1997).

For the sake of tolerating uncertainty without losing hope, it can be suggested that every case-specific team should have one member with sufficiently long experience of treating a psychotic crisis network, and with a family orientation, mainly in the outpatient setting (Aaltonen et al., 2000). It is worth noting that multiprofessional culture-syntonic family therapy training programs have already been implemented to help staff to meet the challenges of engaging in a 
dialogue involving the clients and several professionals (Aaltonen, Seikkula \& Lehtinen, 2011).

The concept of shared decision making (SDM) has been used mainly to refer to dyadic interactions between a client and a practitioner (see e.g. Deegan \& Drake, 2006). In addition to being psychotherapeutically-oriented, multiprofessional family discussions therapy meetings are also scenes of shared decision making. As in studies concerning SDM, the patients (and family members) in this research often felt they had less influence than they would have wished, and they also felt a long-term compassionate relationship to be important (Patel, Bakken, \& Ruland, 2008; Quirk et al., 2012; Seale et al., 2006). However, the results of this research indicate that, before making any crucial decisions, the main goal at the start of treatment for psychotic crises should be the creation of dialogue with the clients, a point which has been emphasized by several other authors (Aaltonen, Seikkula, \& Lehtinen, 2011; Haarakangas, 1997; Lysaker, Buck, \& Hammoud, 2007; Seikkula, Alakare, \& Aaltonen, 2011). If the clients had no feeling of being respected or listened to by the staff, this was likely to lead to significant problems for future co-operation and for any kind of shared decision making. Here it should be noted that the general tendency in treatment has been to avoid talk of psychotic symptoms (McCabe et al., 2002; Seikkula, 2002). In contrast to this, efforts should be made to respond to psychotic speech for example, by saying aloud the words of the patient so that she/he has an experience of being listened to (Seikkula \& Arnkil, 2005).

In the research anxieties and tensions related to the psychotic symptoms tended to lead professionals to take actions to control the symptoms via medication and inpatient treatment, which again had several problematic consequences. Especially in inpatient care, there was a clear risk that difficulties concerned with treatment would overwhelm talk of more essential issues bound up with the psychotic crisis. On the other hand, within the outpatient setting, some psychiatrists avoided difficult issues in order to ensure the continuation of cooperation.

The opportunity to construct a comprehensible psychosis narrative based on authentic dialogue has been found to be important for the recovery and therapeutic change of patients (Geekie \& Read, 2009; Holma, 1999; Karatza \& Avdi, 2011). If the basis of the treatment was purely to control the symptoms and to simply define them as sign of an illness, this chance was missed. The predominance of psychiatric discourse underestimates human experience; it also threatens the agency and empowerment of clients and dialogue between clients and professionals. Furthermore, it easily disregards the positive or ambivalent aspects of psychosis (Moritz et al., 2013). From this point of view, family psychoeducation - which is emphasized within the current evidence-based tradition (Working group appointed by the Finnish Medical Society Duodecim and the Finnish Psychiatric Association, 2013) and in other firmly structured approaches based strongly on the dominant biogenetic illness model - can be problematic. Here it should also be noted that heavily structured approaches do not take into account phenomena which exist in real-world situations, including 
(crucial) clinician-clinician relationships, hectic everyday practices, and the strong emotions of professionals. All of these phenomena were visible in the present research.

The research indicates that from the point of view of the local context, universal claims of truth constitute a threat to the agency of professionals in case-specific terms. Thus, if antipsychotic medication was seen as a self-evident measure, this stance complicated the processes that were needed if clients were to find their own attitudes to drugs. As Austin (2008) has noted, there is a clear risk of actions becoming agent-less. By contrast, the tendency of psychiatrists to avoid the use of a diagnosis of schizophrenia - which is supported by research criticizing the biogenetic approach (Read, 2013a; Read, Haslam, \& Magliano, 2013) - can be seen as a sign of personal agency, and of a willingness to take a different position from the currently dominant evidence-based tradition (Working group appointed by the Finnish Medical Society Duodecim and the Finnish Psychiatric Association, 2013). If we are to help the patients and their families to find ways dealing with psychotic situations, we need to base our work on professional expertise and on interactive work, in other words, to apply both vertical and horizontal knowledge (Aaltonen et al., 2000; Laitila, 2009). There is evidence that patients and also family members have greater belief in the psychosocial causes of psychosis, but that they are both able and willing to integrate multi-factorial and contradictory accounts of psychotic experiences (Aderhold \& Gottwalz, 2013; Geekie \& Read, 2009; Read \& Magliano, 2012; Read, Magliano, \& Beavan, 2013; Read \& Seymour, 2013; Stern et al., 1999; Treanor, Lobban, \& Barrowclough, 2013). Qualitative studies such as those presented here reveal issues which are difficult or even impossible to detect using quantitative methods. Hence, one might ask if - in addition to using randomized controlled trials - the evidence-based tradition should pay more attention not merely to studies that use quantitative methods within a naturalistic research setting (Kissling, 2001; Seikkula, 2005) but also to qualitative research.

On the basis of the present research, it appears that relationships are a crucial issue in the experiences of the clients, and in the work satisfaction of the staff. As has been mentioned previously, psychotherapy research has demonstrated fairly convincingly that therapy outcomes have a particularly strong dependence on the therapeutic relationship (see e.g. Lambert, 2005; Lambert \& Barley, 2002; Norcross \& Wampold, 2011b), and there is evidence that the therapeutic relationship also has a role as an independent predictor of treatment outcome in cases of psychosis (Frank \& Gunderson, 1990; McCabe \& Priebe, 2004; Priebe et al., 2011). If professionals were able to evaluate their (occasionally strong) emotions and the criticism of the clients regarding issues affecting the therapeutic relationship, and to modify their own responses accordingly, this would probably benefit the clients. 


\subsection{Clinical implications: how to better adapt the treatment of psychosis to the needs of the clients}

While confirming the relevance of the main principles of NAA (Aaltonen, Seikkula, \& Lehtinen, 2011; Alanen, 1997; 2009; Seikkula, Alakare, \& Aaltonen, 2011; Seikkula \& Arnkil, 2005), the results also revealed major challenges in applying the approach to real-world clinical practice. In a paper concerning the Open-Dialogue Approach, Aaltonen et al. (2011) have highlighted the locallybased family therapy training programs. These are set up in such a way as to be syntonic with the local culture, multiprofessional, and continuous, and they integrate NAA principles with the reflective approach (Andersen 1994). The present research suggests that to maintain their sense of agency, the psychiatrists who treat persons experiencing a psychotic crisis should have training and supervision. This will enhance their self-reflexive and relational skills, and their ability to tolerate uncertainty, as an alternative to emphasizing the control of psychotic symptoms. Here one can identify a major challenge for local institutions, and especially for the authorities responsible for the specialization of psychiatrists. It can be suggested that the training should avoid the dominance of medical discourse, promoting rather a focus on psychosocial issues and on the use of clients' words, regarding these as attached to human experiences. STR-I seemed to be an excellent method for use in training and in supervising, with the potential to increase psychiatrists' self-knowledge knowledge applying to both their use of language and their non-verbal communication. It could also assist professionals' awareness of the resources of the patients.

Although there were some specific advantages concerning in-patient treatments, generally speaking the clients and the professionals experienced far more problems in hospital than in outpatient care. Unsurprisingly, some of these difficulties arose from the more serious clinical state, which had probably influenced the choice between outpatient and inpatient treatment in the first place. However, the situation was also affected by the reciprocal interaction between the clients and the team (Keränen, 1992), and by the resources, structures, and historical practices in the district. There seems to be a clear risk that both the clients and the professionals will experience psychiatric hospitals as distressing (Hardcastle et al., 2007), and that people's actions will become agentless (Austin, 2008). This is not surprising when one considers the real-life situation in a psychiatric ward; here there can typically be about fifteen patients, often feeling extremely bad, plus worried family members, and several professionals acting in three shifts, all acting under the stigmatizing pressures (see e.g. Read, Haslam, \& Magliano, 2013) of society. Professionals, particularly psychiatrists, should constantly bear in mind that admission to a psychiatric hospital is a major decision. In addition, local and national managers and policymakers should bear the responsibility of developing suitable alternatives, including the resources needed to take care of psychotic crises on an outpatient basis. 
Irrespective of the above, one recommendation could be that when hospital treatment is needed, it would be worthwhile for the psychiatrists and other professionals from outpatient care to take part in inpatient treatment. According to the results of the research, this caused the clients and professionals to discuss unpleasant experiences such as involuntary committal; for their part, the psychiatrists were led to consider whether the team in the outpatient setting could have done something differently, to avoid hospitalization in the first place.

When there were difficulties in the treatment associated with complicated emotions and blame, the CR-Is tended to function as a critical evaluation of the treatments. The interview method obviously helped the clients to speak more openly about their disappointments, hurts, and other bad experiences. In addition to the interviewer as a third party, the reflexive structure of the discussion (Andersen, 1997) - which separates the turns of speaking and listening - can be seen as increasing the participants' possibilities to say somewhat more about delicate matters. As an alternative to the team having a discussion with the supervisor to construct a shared image that would guide the treatment process (Aaltonen \& Räkköläinen, 1994), CR-I could be recommended for use as a means of evaluating the therapeutic relationship and directing the treatment process, at least when there are difficulties in treatment cooperation. The critical voices of patients and family members should be seen more from the point of view of the therapeutic relationship, giving possible hints as to changes which should be made.

Even though adherence to the principles of ODA (see e.g. Seikkula, Alakare, \& Aaltonen, 2011) can contribute to the work of professionals, our results indicate that many important aspects of NAA - for example active and constant assessment of medication - are hard to carry out in a real-life setting. In order to evaluate individual treatment processes - for example to predict failures - NAA should include routine measures to obtain honest feedback from the clients. Psychotherapy research has demonstrated that measures of the alliance and the outcome can improve the success rate and predict failures (Lambert et al., 2002; Miller et al., 2005). There is also some evidence that measuring the therapeutic relationship (McCabe \& Priebe, 2004; Priebe et al., 2011) and the needs of individual patients (van Os et al., 2004; Priebe et al., 2007) could benefit treatment outcome in psychosis.

One can suggest that the voices of the clients who have experienced psychosis should have more weight, not just in individual treatment processes but also in training and research in NAA. As highlighted by a psychiatrist in the study, experience-based experts could have much to contribute in training psychiatrists in their use of language. In the UK, the voices of users and carers have an important role in the current care guidelines for schizophrenia (The Schizophrenia Update Guideline Development Group and National Collaborating Centre for Mental Health, 2010). Here in Finland we are still waiting for a project in which the patients would participate. This indeed was one of the main 
conclusions of the most recent national research and development projects concerning NAA (Aaltonen et al., 2000).

From the family therapeutic perspective the results emphasize that the voices of siblings and friends in particular entailed resources for recovery. The psychiatrists were also more capable of listening to the critical views of the siblings than those of the parents. Here it is worth noting that no male family members attended our interviews. This is parallel with common clinical experience, and with research (Stern et al., 1999) indicating that women have the primary role as carers. Furthermore, the team occasionally paid more attention to the views of the relatives than those of the patient. In the worst cases, when team members felt compelled to defend themselves against the criticism of family members, the patient was left alone between the two disagreeing parties. As a general conclusion, from a family therapeutic perspective, this research indicates that fathers or other male relatives, siblings, or friends might be involved more often in the therapy meetings. In addition, in relation to the patient and to all other members of the family the staff ought to focus on striving towards an equal alliance, since this is considered to be one of the main effective common factors in family therapy (Sprenkle, Davis, \& Lebow, 2009).

All of the experienced psychiatrists in this research were fully aware of their major role as an authoritarian figure for their co-workers, a point which has been observed also in other studies (e.g. Jimmieson \& Gallagher, 2010; Vuokila-Oikkonen, 2002). One practical way of having more relational responsibility (McNamee \& Gergen, 1999) and respect for colleagues - as emphasized by relationship-centered care (see e.g. Beach \& Inui, 2006) - could be that the psychiatrists in therapy meetings would base their own speech not just on the words of clients but also those their co-workers have used in their practice. However, one should also pay attention to the extremely challenging positions of psychiatrists, as seen in this study. The study emphasizes how important it is for them to receive the unequivocal support of the administration. This has indeed been found to be of major importance for the professionals within psychosis teams (Aaltonen et al., 2000).

\subsection{Reflections on the research process}

\subsubsection{Strengths and limitations of the research}

The limitations include the high proportion of family therapists in the sample, and the psychiatrists' varying commitment to NAA. These aspects are dealt in the original papers. Additional specific matters arise, for example, in so far as it would have been desirable to have male family members taking part in the interviews. This would have made the data more multifaceted. Furthermore, during the process in which the results were written out as a kind of narrative, some details could have been overlooked, with complicated issues becoming over-simplified as a result. 
In addition to these more specific aspects, there are some general issues relating to the strengths and limitation of the research. First of all, caution is needed concerning the generalizations that are possible on the basis of the findings, which were based on a small number of selected interviewees. On the other hand, according to Silverman (2005), the validity of qualitative analysis depends more on the quality of the analysis than on the size of the sample; to achieve an effective analysis it may actually be better to have a limited body of data. In terms of all the main research questions, the applicability of the results is supported by my clinical experiences as a practitioner, and also by several other studies on NAA (as well as by other approaches to the treatment of psychosis). Nevertheless, they should be interpreted more as plausible aspects of the real-world treatment of psychosis than as universal truths.

Some of the results may apply also to other severe mental disorders, even if the special features of the psychosis phenomenon are clearly present in the present study. From the recovery perspective (see e.g. Anthony, 1993; Topor, 2004) there is a substantial degree of commonality, for example in the experiences of the clients, regardless of the diagnosis. In this sense one of the strengths of the study is that it may contribute to an understanding of the experiences of professionals who are working in the public sector, treating a whole range of severe psychosocial problems.

For unknown reasons, truly challenging cases were selected for the research. All the patients were given antipsychotic medication, and most of them underwent inpatient care as well - only two cases were treated completely on an outpatient basis. Although this can be seen as a strength, it is also one of the main limitations of the research, which has very little to say about those treatment processes - perhaps the most successful ones - in which treatment is provided without the need for neuroleptics or hospitalization (see Mosher \& Bola, 2013; Seikkula et al., 2006).

In evaluating the strengths and limitations, one should bear in mind that the psychiatrists described their inner dialogue within the CR-I, not during an actual therapy meeting, and that two of the biphasic interviews took place after the actual treatment cooperation was over. Nevertheless, the main issues concerning psychosis and the arousal of emotions seemed to emerge surprisingly strongly even in the single CR-I that was conducted about one year after the therapeutic relationship had ended. This supports one of the main findings of the research, namely that the psychiatrists responded as embodied individual human beings, people who have strong emotions as they interact with clients and with other professionals. On the other hand, it is entirely possible that if the STR-Is had been based on videos from actual instances in the treatment, different results would have been obtained.

Both interview methods used in the present research showed some strengths in a clinical sense. They improved psychiatrists' opportunities to have agency in terms of how to use their inner dialogue for the benefit of clients. Separating the turns of listening and speaking in the CR-I opened up space for all parties to say more and to hear more. In the CR-Is the psychiatrists had more 
space for their inner dialogues concerning emotionally difficult issues, they were able to pay attention to the patients' health, resources, and agency, and to position themselves constructively towards the critical views of clients. As far as the STR-Is were concerned, these made the psychiatrists more aware of their own contribution to the interviews. They became aware of the phrasing they used, and of other explicit choices, observing also their nonverbal embodied responses. They also found therapeutically useful words for their difficult experiences. All in all, STR-I seemed to emerge as a suitable method for studying professionals' inner dialogues.

The research design as a whole was not rigid, and it became modified in the course of all the main steps of the study. In the first pilot interview I (as interviewer) chose video segments from the CR-Is for closer study in the STR-I. On the basis of that experience, for the later STR-Is I decided to conduct a brief inquiry (by telephone or e-mail) with the psychiatrists, asking them whether there were any particular parts of the CR-I which had led the psychiatrist to ponder or to experience emotions, during the interview or afterwards. I used the answers given to search out the CR-I segments in question. Later, in the STR-Is, these segments were focused on. The aim was thus that the inner dialogues that took place after the CR-Is would guide the search for segments of the videotapes to be watched in the STR-I. Here it should be pointed out that the interview methods were not used rigorously; they were literally inter-views, dialogical conversations on themes of mutual interest (Kvale 1996). The interviews, and also the telephone or e-mail inquiries that took place before each STR-I, were in each case modified according to previous experiences and conversations.

The two different analytical methods that were used were applications whose purpose was utilize the data effectively in line with the needs of the research questions. Although the lack of rigor here might be seen as a weakness, there are contrary viewpoints. Thus, Kvale (1996) uses the traveler metaphor: this sees the interviewer as wandering together with the interviewees, in search of a story to be told upon returning home. Silverman (2005) points out that in qualitative research, sticking with original research design can as often as not be a sign of inadequate data analysis.

One aspect with an impact on these modifications and variations was my position as a scientist-practitioner. According to Kvale (1996), one should distinguish biased subjectivity - which should be avoided - from perspectival subjectivity. Rather than attempting to eliminate any personal interaction, I took leads from my own therapeutic experience, regarding myself as a methodological tool. My own voice as researcher no doubt had a clear influence on the course of the interviews. Turning again to Kvale (1996), it can be suggested that the strength of an interview conversation lies in its ability to capture the multiple nature of the subjects' views on the theme. In order to describe this aspect of the data more clearly, future analysis would have to focus on the impact of the researcher. Based on the current analyses, it can be said that my perspective on psychosis and my training as a family therapist - my perspectival 
subjectivity - could be clearly seen in the data. The lack of rigidity, including the tendency to modify research methods dialogically during the process, using my own person as a tool, seemed to open up space for discussing delicate matters. However, at the same time, it might well have concealed matters that a stricter stance would have uncovered.

\subsubsection{Ethical considerations}

Haverkamp (2005) considers research ethics from the perspective of the scientist-practitioner. According to her, our scientist selves should be aware of our tendencies to be selective and hence to disregard relevant information. On the other hand, regarding our practitioner selves, we should be aware of the asymmetry of power in the relationships between the researcher and the participants ${ }^{11}$. The ethics of the research should be evaluated on the grounds of the actual incidents and interactions in the research: human interaction, which is the basis of the data, is not predictable. After participants have decided to participate in research and have given their informed consent, they are potentially vulnerable to researcher influence. They do not know in advance what their experiences of the actual dialogue within the interviews will be. As was seen in the present research, unexpectedly intense emotions emerged on the part of the participants. The person of the researcher becomes an integral part of the process, since he/she is faced with difficult - often spontaneous - decisions. All in all, in this research, the goal of control was abandoned, and one can say that the research design itself had dialogical properties.

In addition to spending their own time in the interviews, in which they experienced at least some emotional turmoil, in the present study the clients and the professionals felt they were sharing information of a personal and intimate nature. Thus, the principle of providing benefit to the research participants, and not just to society, can be considered to have ethical value. However, as there were several research participants present in the same interviews, it should be recognized that some actions might have resulted in benefit for some and harm for others. Within the protocol, space was given for the interviewees to talk about their experiences of the interviews. Most of the clients experienced the interviews as useful or interesting. Although some of them did not mention any personal benefit, none of them spoke of harm. As some of the clients appeared to be nervous, the interviewer took this into account in attempting to make the experience more pleasant. The professionals experienced the interviews as useful, and in all those six cases in which they still had a therapeutic relationship with the clients, they deemed the interviews to be beneficial for the treatments. As a means of minimizing harm to the therapeutic relationship, it

11 One aspect of the power relation, not mentioned by Haverkamp, is the researcher's attitude to the participants' competence. The researcher has a responsibility to relate to the participants as competent individuals with their own resources, able to respond in the interviews in a way that is suitable for them in that context. The researcher should not overlook the participants' capabilities. 
was decided at the very beginning of the research that the professionals would choose the clients for the study.

From a scientific perspective, it might have been more relevant to study an authentic therapy meeting, but the use of CR-I can be considered more ethical. In so far as CR-I is used as a method for evaluating therapeutic processes together with the clients and the therapists, it is designed to produce benefits for the participants. It improves transparency for the clients, who gain an idea of what the researcher is doing; furthermore, it enables the researcher to take more responsibility for the impact of his research - seeking always to benefit the client and to avoid harm. For persons with psychotic experiences, the use of videos of therapy meetings, in which the researcher would have been a silent observer or not present at all, might have been especially problematic

According to Guillemin and Gillam (2004) researchers should have sensitivity to ethically important moments, which are often unexpected and call for immediate decisions on matters of ethical concern. Guillemin and Gillam argue that ethical responsibility requires reflexivity and that researchers should acknowledge the ethical dimensions of ordinary, everyday research practice i.e. microethics. In the present research, there were several ethically important moments in the interviews, moments that contained possibilities for at least some emotional harm. In those instances I took the position of a clinical psychiatrist, a therapist, or a supervisor, emphasizing the benefit of the research for participants at the expense of scientific neutrality. For example, if the clients in the CR-Is started to speak about their psychotic experiences or of traumas involved in the treatments, I - as the person with the main responsibility abandoned the neutral position of a scientist and instead responded according to my therapeutic ethical standards. From the perspective of research, I actually became one of the psychiatrists whose inner dialogue was being studied. Nevertheless, although the aim was to take account of the richness of human interaction, one cannot exclude the possibility that something was overlooked. All that can be said is that the basic attitude was one of trying to avoid causing harm, and of trying rather to benefit the interviewees.

In making ethical choices of this kind, one loses some of the rigor desirable in scientific research. On the other hand, if participants have the experience of being listened to, respected, and emphatically understood by the researcher, it is likely that they will have more confidence and be willing to speak more openly. In this sense the dialogical nature of the whole research process - and also of the individual interviews - conformed to principles that are important for the trustworthiness of the research, and for the scientific value of qualitative studies based on in-depth interviews.

According to Haverkamp (2005), research participants may have a tendency to position the researcher according to his professional training. In addition to the issues mentioned above, there were indications in the present research that collegiality had an impact on the STR-Is. Often this made it easier, but occasionally more difficult, for the psychiatrists to give sincere answers. 
A special challenge for studies resting on extensive quotations is to modify them in such a way as to guarantee the anonymity of the participants, while at the same time not losing their authenticity and strength as evidence (Haverkamp, 2005). Even though it is simple to change the stories in such a way that the general public cannot identify the interviewees, in situations where there are only a few participants from a particular sector of health care there is a risk that the professionals might be identified, for example by their workmates. As could be seen in the first study (dealing with the psychiatrists' experiences of their co-workers), this is a matter of great importance. Protection of the identity of any third parties mentioned (something emphasized by Haverkamp) was also a relevant issue in the present research. Occasionally compromises had to be made for the sake of confidentiality, with some possible blurring of the phenomena which the study was attempting to capture. Nevertheless, there is still a slight possibility that the participants could recognize each other or themselves from the interview extracts, and be dissatisfied with the researcher's interpretations.

It should be pointed out that if the ethical perspective of the research is overemphasized the consequence might be that qualitative studies would become impossible in a real-life setting. This, once again, underlines an important ethical dilemma within psychiatric practice. Here it can be suggested that the ethical arguments cut both ways: concerning the treatment of psychosis in particular, it is ethically extremely important to gain an understanding of professionals' human embodied relationships and emotions. Although they may have a major impact on real-world clinical practice, the issue has been almost totally ignored by research.

\subsubsection{Personal reflections: confirmations and surprises}

For me as a practioner-researcher, someone who has worked as a family therapeutically trained psychiatrist, treating psychosis and other severe mental disorders over two decades, this project has been significant in several ways. The detailed and broad reading of the research literature on psychosis, which I have undertaken ever since the research project started in 2005, has changed many of my previous views on the phenomenon of psychosis and its treatment. Even though before starting this research I knew the research literature concerning NAA, a better acquaintance with the rich foreign research criticizing the dominance of the biomedical approach (see Bracken et al., 2012; Morrison et al., 2012; Read \& Dillon, 2013; Whitaker, 2003) has made me more aware of the severe problems concerning, for example, diagnostic categories and the use of antipsychotic drugs - aware, too of the impact of the pharmaceutical industry.

It has been illuminating for me to discover that although international approaches to early psychosis (see Gleeson \& McGorry, 2005) emphasize CBT and advanced family psychoeducation, they stress many of the principles of NAA. Furthermore, I became strongly aware of the fact that the evidence-based recommendations for the treatment of schizophreania (Buchanan \& Keller, 2010; Dixon et al., 2010; Kreyenbuhl et al., 2010; The Schizophrenia Update Guideline 
Development Group and National Collaborating Centre for Mental Health, 2010; Working group appointed by the Finnish Medical Society Duodecim and the Finnish Psychiatric Association, 2013) have major differences - while at the same time being strongly socially constructed.

All in all, concerning the literature on recovery and on the experiences of service users (see Anthony, 1993, 2006; Anthony, Rogers, \& Farkas, 2003; Currie, 2011; Geekie \& Read, 2009; Jacobson \& Greenley, 2001; May, 2005; Moritz et al., 2013; Roberts \& Wolfson, 2004; Topor, 2004), I can say that this has had the most significant impact on me, not just as a clinician, but also as a person. In addition to giving me some clinical tools, including the concept of douple awareness (Topor, 2004), and the importance of spiritual explanations of psychotic experiences (Geekie \& Read, 2009), it has made me more aware of the adverse effects of psychiatry - yet at the same time, of the power of human relations, resilience, and hope, even after severe and prolonged difficulties.

The interviews contained a great many instructive surprises. Although the psychiatrists turned out to be unexpectedly sensitive in their capacity to evaluate themselves from a critical position, at the same time they seemed to be highly vulnerable to the criticism of others. Regardless of the interviewer's questions, all the interviewees tended to speak of those issues which had been significant for them in the treatment context. Even though a year had passed since the CR-I, the main issues that had emerged in the discussion still seemed to have an emotional tenor, based on the therapeutic cooperation that had existed between the participants. This observation seemed to run parallel with the views of Fuchs and de Jaegher (De Jaegher, Di Paolo, \& Gallagher, 2010; De Jaegher \& Froese, 2009; Fuchs \& De Jaegher, 2009), to the effect that the interactive processes and coordinations of embodied agents form a common incorporality, which has some autonomy in itself. The experiences of the interviews strengthened my previous understanding of the usefulness of separating speaking and listening, particularly in challenging situations. The use of both interview methods, plus the time intermission in the process, appeared to allow the interviewers to gain some distance from the emotional turmoil, and to have more room for their inner dialogue, supporting their sense of agency.

The results of all the three studies brought forth several confirmatory elements, but more surprises. The preliminary story I compiled (Borchers, 2009) - which was based on my own thoughts and experiences, and which was summarised in the second article - differed considerably from the actual results of the study. Although there were indeed some comments on diagnosis, medication, and psychoeducation, scientific discourse touching on the actual treatment of psychosis played only a minor role in the inner dialogues of the interviewees. The major role of emotions and relationships among professionals increased my understanding of the profoundly human nature of the psychosis phenomenon.

Even when the actual treatment co-operation was over, the clients and the professionals seemed to position themselves in such a manner that the research 
interviews largely became therapeutic sessions. As mentioned previously, this aspect was not independent of the interviewer. It appeared in fact that nobody had unidirectional control of the discussion in the interviews, and that rather, each participant was influenced by the positioning of the others. Occasionally some participants seemed to join together to form one dialogical agent. Thus, they might complete sentences which had been started by another participant. One phenomenon that became apparent was the psychiatrists' inner dialogue as it functioned in the search for agency. They changed their words or commented on what was previously said, attempting to find suitable responses for the actual context.

Altogether, this research has made me more convinced of the major importance of the human perspective in meeting with persons who are suffering from psychosis; it has also made me more humble as a clinician. At the same time I have become more aware of the importance of the language used with clients. Especially with respect to the psychosis phenomenon, the institutional voices of psychiatric discourse appear to have an enormous suppressing power, which is probably the complete opposite of what is needed for the recovery of the clients. Certain more personal impacts are illustrated at the beginning and at the end of the introduction, in the verses of a poem inspired by the research project.

\subsection{Future research}

There are several questions for future research, some of which can be studied using the same research material. During the third study, the first steps in studying one of these questions were already taken. Preliminary analysis indicates that there are significant issues bound up with the voice of the interviewer and its impact on the therapeutically meaningful changes within the interview processes. A more detailed analysis will have to be undertaken in order to clarify the significance and the trustworthiness of the conclusions in this regard. In addition, it appeared that the interviews had therapeutic impacts, and that the interviewer occasionally took the position of a clinician. Thus, a detailed analysis of the voice of the interviewer might well reveal something of importance concerning the treatment of psychosis.

The inner dialogue of professionals, which seems to have an impact on the treatment processes, should be studied further. The present data indicated that especially in STR-Is, the psychiatrists' inner dialogue could be seen in both their verbal and their nonverbal communication. They interrupted their own speech, kept quiet for a while in order to find a suitable word, changed something they had already said, or determined beforehand something they were going to say. A more comprehensive microanalytic study of this inner process of taking agency within one's own speech might provide a better understanding of professionals' inner dialogue. In addition the interview material of this study contains one STR-I with a nurse who attended the 
corresponding CR-I. Analysis of that interview would make it possible to compare the inner dialogues of professionals from different occupations who are dealing with the psychosis phenomenon.

To the best of my knowledge, this is the first in-depth study of professionals' inner dialogues in the treatment of psychosis. A pure repetition involving a similar research project - possibly dealing also with some other severe mental disorders and with professionals from several occupations - would give valuable additional knowledge. A study of professionals' inner dialogues in authentic NAA therapy meetings would be one possible direction. An interesting line of research would be to have a case study of an individual NAA therapy meeting, focusing on the inner dialogues of all participants. Another future direction might be to conduct a survey of psychiatrists (and other professionals) who treat psychosis; the aim would be to evaluate quantitatively some of the main results of the present research, including the impacts of strong emotions, clinician-clinician relationships, institutional forces, and difficult experiences such as those arising from coercive measures

This research also indicates some more general needs for future research. It is likely that all psychotherapeutically-based treatment processes would benefit from routine measures to obtain feedback from clients (see Lambert et al., 2002; Miller et al., 2005). Like all treatment processes, NAA treatment runs the risk of failure or inadequate success. Viewed from this perspective, one can see the potential value of investigations to discover measures that could be used routinely in NAA therapy meetings for psychotic crisis.

This research, in conjunction with the literature on relationship-centered care (e.g. Beach \& Inui, 2006; Safran \& Beckman, 2006) shows the importance of the relationships between professionals, a topic which remains relatively unstudied. There is a need for a variety of qualitative studies on the relationships between clinicians in the real-life context of the treatment of psychosis; this should make it possible to gain a more accurate picture of the issue, and of its impact on the recovery of the clients. And finally, we in Finland would probably benefit from a more intensive program of research on psychosis, or - as the report of the API project (Aaltonen et al., 2000) concluded - a new national research and development project, in which clients would participate.

My heart thumps against my chest, it wants to fly out into space and beat, like a cosmonaut it dives.

Slave, cast off the chains of gravity. 


\title{
YHTEENVETO (SUMMARY)
}

\section{"Tällasetkin asiat vaikuttaa" - psykoosien tarpeenmukainen hoito ja psykiat- rien sisäinen keskustelu}

\author{
Juoksevat jalat ompelevat asfalttia, juovut ilmasta, \\ tuuli katsoo syvälle silmiisi ja aurinko puhaltaa sinut valoksi \\ kuin kynttilän \\ lennät ilman varjoa, enemmän kuin koskaan \\ ihminen, \\ kunnes katseesi osuu hetkeen jota et näe, jota ei ole \\ ja maa vetää puoleensa haudan syleilyyn.
}

Tämän tutkimuksen tavoitteena oli kuvata psykiatrien sisäistä keskustelua psykoosien tarpeenmukaisen hoitomallin kontekstissa eli yhteistyösuhteessa, joka muodostuu potilaiden, heidän sosiaalisen verkostonsa ja toisten ammattilaisten keskelle. Tutkimus pyrki näyttämään, että työntekijöiden kokemuksella voi olla vaikutusta hoitoon, sekä selvittämään, miten ammattilaisten sisäistä keskustelua voidaan tutkia. Tämä laadullinen tutkimus kiinnittyy suomalaisen psykoosien tarpeenmukaisen hoidon laajaan ja rikkaaseen tutkimusperinteeseen.

Tutkimuksessa oli mukana kolmelta eri maantieteelliseltä alueelta viisi klinikkaa, jotka olivat erikoistuneet ensipsykoosien hoitoon. Klinikoiden työntekijät valitsivat ja kutsuivat tutkimukseen potilaat, joita oli hoidettu skitsofreniaryhmän psykoosin (ICD-10 diagnoosi F20-29) vuoksi korkeintaan kaksi vuotta, sekä heidän perheenjäseniään. Tutkimukseen otettiin tarkasteltavaksi kahdeksan hoitoprosessia. Kahdeksasta psykiatrista, joista kaksi osallistui kahteen haastatteluun, naisia oli seitsemän ja miehiä yksi. Iältään he olivat 36-61 vuotta. Kolme heistä työskenteli pelkästään avohoidossa ja kolme ainoastaan sairaalassa. Kaksi avohoidosta vastaavaa psykiatria osallistui myös osastohoitoon. Kuudella psykiatreista, joista neljä oli perheterapeutteja, oli pitkä kokemus psykoosien hoidosta. Kaksi kokematonta psykiatria oli parhaillaan erikoistumiskoulutuksessa. Kaikissa tutkimushaastatteluissa oli mukana hoitoon osallistuneita työntekijöitä, jotka olivat ammatiltaan sairaanhoitajia tai psykologeja. Potilaista, jotka olivat iältään 19-56 vuotta, puolet oli naisia ja puolet miehiä. Yhtä haastattelua lukuun ottamatta tutkimukseen osallistui myös perheenjäseniä, jotka olivat potilaiden äitejä tai sisaria. Kaksivaiheiset videonauhalle tallennetut tutkimushaastattelut tehtiin elokuun 2007 ja tammikuun 2009 välillä. Ensin psykiatreja haastateltiin yhdessä potilaan, perheenjäsenten ja työtovereiden kanssa soveltaen yhteisen tutkimisen haastattelua (Andersen, 1997). Siinä hoitoprosessia arvioidaan yhdessä vuorottelemalla puhumista ja kuuntelua niin, että ensin työntekijät ja sitten asiakkaat arvioivat hoitoyhteistyötä toisen yhteistyöosapuolen kuunnellessa. Yhteisen tutkimisen haastattelujen jälkeen tutkija teki psykiatreille lyhyen kyselyn, minkä pohjalta valittiin videolta tutkittaville merkittävät kohdat katsottavaksi stimulated recall -haastatteluun (Elliott, Slatick \& Urman, 2001). Siinä tutkittavia pyydettiin muistelemaan ajatuksiaan ja tunteitaan videolta katsomassaan kohdassa ensimmäisestä haastattelusta. Stimulated recall -haastattelut, mukaan lukien siinä yhteisen tutkimisen haastatte- 
lusta katsotut kohdat, litteroitiin tekstiksi, joka jaettiin edelleen aihe-episodeiksi (Linell, 1998). Tämä teksti toimi kaikkien kolmen osatutkimuksen pohjaaineistona. Kahdessa ensimmäisessä osatutkimuksessa sovellettiin dialogista tai dialogis-narratiivista analyysimenetelmää (Markova ym., 2007; Rober, Seikkula \& Laitila, 2010; Wortham, 2001) ja kolmannessa osastutkimuksessa laadullista sisällön analyysiä (Graneheim \& Lundman, 2004).

Tutkimuksessa käytetyt menetelmät osoittautuivat yhdeksi mahdolliseksi tavaksi tutkia ammattilaisten sisäistä keskustelua. Tutkimuksen keskeiset löydökset kliinisen toiminnan näkökulmasta olivat seuraavat: (i) vuorovaikutuksessa asiakkaiden ja toisten ammattilaisten kanssa psykiatrit vastaavat toisten vuorovaikutukseen kehollisina inhimillisinä yksilöinä, joilla on vahvojakin tunteita, mikä viittaa siihen, että eri osapuolten kokemukset ja sisäiset dialogit voivat olla keskenään riippuvaisia; (ii) työntekijöiden keskinäiset suhteet saattaa olla tärkeä hoitoon vaikuttava tekijä; (iii) erityisesti sairaalahoidossa institutionaaliset ilmiöt voivat vaikuttaa oleellisesti psykiatrien toimijuuteen vähentämällä heidän luovuuttaan ja johtaa ajoittain tilanteisiin, joissa yksittäisten työntekijöiden inhimillinen toimijuus näyttää kokonaan katoavan; (iv) psykiatrit näyttävät olevan enemmän tai vähemmän tietoisia erityisesti sairaalahoitoihin liittyvistä monista haitoista; (v) tutkimuksessa käytetyt haastattelumenetelmät lisäsivät ammattilaisten mahdollisuuksia itsereflektioon, ja ne voivat olla käyttökelpoisia apuvälineitä käytännön työn haasteissa.

Psykoosi-ilmiö ja siihen liittyvät isot eettiset kysymykset herättivät vahvoja tunteita sekä asiakkaissa ${ }^{12}$ että ammattilaisissa. Usein mukana oli voimakasta kritiikkiä, mikä puolestaan lisäsi psykiatrien emotionaalisia paineita. Erityisesti kokemattomat psykiatrit tarvitsivat tukea kokeneilta työtovereiltaan, mitä ilman heidän oli vaikea pitäytyä tarpeenmukaisen hoitomallin humaaneissa periaatteissa. Psykiatrisilla osastoilla potilaat nähtiin helposti pelkästään sairaudesta käsin, ja henkilökunta oli vaarassa tottua jopa epäinhimillisiin toimintatapoihin. Jos asiakkaat olivat kokeneet vastentahtoisia hoitotoimia tai epäoikeudenmukaista tai epäkunnioittavaa kohtelua, jotta hoidossa päästäisiin eteenpäin, näitä asioita piti käsitellä. Kaikki osapuolet kokivat avohoidon pääsääntöisesti sairaalahoitoa myönteisempänä. Kuitenkin jotkut potilaat hyötyivät osastolla esimerkiksi vertaistuesta, ja joskus psykiatrit kokivat olevansa avohoidossa liian varovaisia ottamaan puheeksi hoidon kannalta oleellisia potilaille vaikeita teemoja. Psykiatrit, jotka osallistuivat sekä avo- että sairaalahoitoon, näyttivät kykenevän noudattamaan parhaiten tarpeenmukaisen hoidon mallia. Tämä asetelma oli heille kuitenkin hyvin haastava ja edellytti henkilökohtaista sitoutumista tarpeenmukaisen hoidon periaatteisiin. Toisaalta tutkimuksen perusteella - johtuen lukuisista paikallisista vaikuttavista tekijöistä - ei näyttäisi olevan mitään yhtä ainoaa oikeaa tapaa järjestää psykiatrien roolia hoidon kokonaisuudessa. Tulosten valossa työntekijöiden kokemukset kannattaisi ottaa huomioon organisoitaessa paikallisia hoitomalleja. Institutionaaliset tekijät vaikuttavat merkittävästi kieleen, jota psykoosi-ilmiöstä käytetään. Tutkimuksen pe-

12 Asiakas-sanaa käytetään viitattaessa samalla sekä potilaisiin että heidän perheenjäseniinsä. 
rusteella yksittäisillä psykiatreilla tulisi olla valtaa ja kykyä sovittaa hoidon arjessa puheensa eri tilanteissa asiakkaiden mahdollisuuksien ja tarpeiden mukaan. Yhtenä esimerkkinä tästä voidaan pitää sitä, että tässä tutkimuksessa osa psykiatreista vältti käyttämästä skitsofrenia-diagnoosia tietoisena tuon käsitteen epätoivotuista vaikutuksista toipumiseen.

Tämän tutkimuksen perusteella psykoottisia kriisejä hoitavat psykiatrit tarvitsevat koulutusta ja työnohjausta, jotka kehittävät heidän vuorovaikutustaitojaan ja itsereflektiotaan sekä heidän kykyään sietää epävarmuutta psykoottisten oireiden kontrolloinnin sijaan. Stimulated recall - haastattelu näyttäisi olevan erinomainen keino käytettäväksi koulutuksessa ja työnohjauksessa lisäämään psykiatrien itsetuntemusta suhteessa sekä sanalliseen että sanattomaan vuorovaikutukseen. Käytännön kliinisessä arjessa psykiatrien tulisi pystyä pitämään kaiken aikaa mielessään, että varsinkin sairaalahoidon aloittaminen on hyvin merkittävä hoitopäätös. Jos osastohoitoon päädytään, näyttää siltä, että avohoidon psykiatrin ja muiden työntekijöiden olisi hyödyllistä osallistua myös sairaalahoitoon. Tämä järjestely voisi edesauttaa osaltaan sitä, että esimerkiksi vastentahtoisiin hoitotoimiin liittyvistä vaikeista kokemuksista käydään usein hoidon etenemisen kannalta välttämätöntä keskustelua. Psykoosiin usein liittyvissä haastavissa hoitoprosesseissa, joissa on vaikeita emootioita ja eri osapuolten välistä syyttelyä, yhteisen tutkimisen haastattelu voi olla hyödyllinen tapa lisätä asiakkaiden mahdollisuuksia puhua avoimemmin kokemistaan pettymyksistä ja hankalista kokemuksistaan. Eri yhteistyötahojen puhumisen ja kuuntelemisen vuorojen erotteleminen vaikuttaa antavan työntekijöille paremmat mahdollisuudet jäädä kuuntelemaan asiakkaiden kriittisiä ääniä hyödyllisinä vinkkeinä yhteistyösuhteen parantamiseksi. Kaiken kaikkiaan olisi hyvä etsiä psykoosien tarpeenmukaisen hoidon reaalimaailmaan sopiva rutiininomainen keino saada asiakkailta rehellistä palautetta, jonka perusteella yksittäisiä hoitoprosesseja voitaisiin luotettavammin ohjata ja uhkaavia epäonnistumisia ennustaa. Asiakkaiden äänillä tulisi olla nykyistä isompi painoarvo sekä yksittäisissä hoitoprosesseissa, palveluiden kehittämisessä, koulutuksessa että tutkimuksessa. Psykoosin kokeneet potilaat voisivat toimia kokemusasiantuntijoina psykiatrien koulutuksessa. Perheterapeuttisesta näkökulmasta tämän tutkimuksen perusteella potilaiden isien, sisaruksien ja ystävien kutsumista hoitokokouksiin kannattaisi ehkä lisätä. Lääkärin asemaan liittyy helposti ongelmallista autoritaarisuutta suhteessa työtovereihin, mitä psykiatrit voivat hoitokokouksissa pyrkiä lievittämään perustamalla omia puheenvuorojaan ei vain asiakkaiden vaan myös muiden työntekijöiden esittämiin näkemyksiin ja sanoihin.

Minun sydämeni koputtaa rintakehään, haluaa ulos avaruuteen sykkimään,

Orja, riisu vetovoiman kahleet. kuin kosmonautti se sukeltaa. 


\section{REFERENCES}

Aaltonen, J., Koffert, T., Ahonen, J., \& Lehtinen, V. (2000). Skitsofrenian tarpeenmukainen hoito on ryhmätyötä: Raportti Akuutin psykoosin integroitu hoito projektin tuottamista hoitoperiaatteista [Need-specific treatment of schizophrenia is teamwork: A report on the treatment principles yielded by the project on the integrated treatment of acute psychosis]. Helsinki: National Research and Development Centre for Welfare and Health (Stakes), Reports, 257.

Aaltonen, J. \& Räkköläinen, V. (1994). The shared image guiding the treatment process - a precondition for integration of the treatment of schizophrenia. British Journal of Psychiatry, 164, 97-102.

Aaltonen, J., Seikkula, J., \& Lehtinen, K. (2011). The Comprehensive OpenDialogue Approach in Western Lapland: I. The incidence of non-affective psychosis and prodromal states. Psychosis, 3, 179-191.

Addington, J. \& Burnett, P. (2004). Working with families in the early stages of psychosis. In J. F. M. Gleeson \& P. D. McGorry (Eds.), Psychological interventions in early psychosis: A treatment handbook (pp. 99-116). Hoboken, NJ: Wiley.

Addington, J., Coldham, E. L., Jones, B., Ko, T., \& Addington, D. (2003). The first episode of psychosis: The experience of relatives. Acta Psychiatrica Scandinavica, 108, 285-289.

Aderhold, V. \& Gottwalz, E. (2013). Family therapy and psychosis: Replacing ideology with openness. In J. Read \& J. Dillon (Eds.), Models of madness: Psychological, social and biological approaches to psychosis (2nd edition) (pp. 378-391). London: Routledge.

Alanen, Y. O. (1997). Schizophrenia: Its origins and Need-Adapted Treatment. London: Karnac Books.

Alanen, Y. O. (2009). Towards a more humanistic psychiatry: Development of need-adapted treatment of schizophrenia group psychoses. Psychosis, 1, 156-166.

Alanen, Y. O., Lehtinen, V., Lehtinen, K., Aaltonen, J., \& Räkköläinen, V. (2000). The Finnish integrated model for early treatment of schizophrenia and related psychoses. In B. Martindale, A. Bateman, \& M. Crowe (Eds.), Psychosis: Psychological approaches and their effectiveness (pp. 235-265. London: Gaskell.

Alhanen, K. (2007). Käytännöt ja ajattelu Michel Foucault'n filosofiassa [Practices and thought in Michel Foucault's philosophy]. Helsinki: Gaudeamus.

Andersen, T. (1994). Reflekterande processer. Samtal och samtal om samtalen [The reflecting team: Dialogues and dialogues about the dialogues]. Smedjebacken: Bokförlaget Mareld.

Andersen, T. (1997). Researching client-therapist relationships: A collaborative study for informing therapy. Journal of Systemic Therapies, 16, 125-133.

Anderson, H. \& Goolishian, H. A. (1988). Human systems as linguistic systems: Preliminary and evolving ideas about the implications for clinical theory. Family Process, 27, 371-393. 
Angermeyer, M. C., Schulze, B., \& Dietrich, S. (2003). Courtesy stigma - a focus group study of relatives of schizophrenia patients. Social Psychiatry and Psychiatric Epidemiology, 38, 593-602.

Anthony, W. A. (1993). Recovery from mental illness: The guiding vision of the mental health service system in the 1990s. Psychosocial Rehabilitation Journal, 16, 11-23.

Anthony, W. A. (2006). Personal accounts: What my MS has taught me about severe mental illnesses. Psychiatric Services, 57, 1081-1082.

Anthony, W., Rogers, E. S., \& Farkas, M. (2003). Research on evidence-based practices: Future directions in an era of recovery. Community Mental Health Journal, 39, 101-114.

Archer, M. S. (2003). Structure, agency and the internal conversation. Cambridge: Cambridge University Press.

Askey, R., Holmshaw, J., Gamble, C., \& Gray, R. (2009). What do carers of people with psychosis need from mental health services? Exploring the views of carers, service users and professionals. Journal of Family Therapy, 31, 310-331.

Austin, W. J. (2008). The balancing act: Psychiatrists' experience of moral distress. Medicine, Health Care \& Philosophy, 11, 89-97.

Bakhtin, M. M. (1981). The dialogical imagination: Four essays by M. M. Bakhtin. Austin: University of Texas Press.

Bakhtin, M. M. (1984). Problems of Dostoevsky's poetics. Minneapolis: University of Minnesota Press.

Bakhtin, M. M. (1986). Speech genres $\mathcal{E}$ other late essays. Austin: University of Texas Press.

Barley, M. \& Harrison, G. (2008). Guidelines or mindlines? A qualitative study exploring what knowledge informs psychiatrists' decisions about antipsychotic prescribing. Journal of Mental Health, 17, 9-17.

Barton, K. \& Jackson, C. (2008). Reducing symptoms of trauma among carers of people with psychosis: Pilot study examining the impact of writing about caregiving experiences. Australian and New Zealand Journal of Psychiatry, 42, 693-701.

Bateson, G. (1980). Mind and nature: A necessary unity. Toronto: Bantam Books.

Bateson, G. (1985). Steps to an ecology of mind. New York: Ballantine Books.

Beach, M. C. \& Inui, T. (2006). Relationship-centered care. A constructive reframing. Journal of General Internal Medicine, 21, S3-S8.

Bentall, R. (2013). Understanding psychotic symptoms. In J. Read \& J. Dillon (Eds.), Models of madness: Psychological, social and biological approaches to psychosis (2nd edition) (pp. 220-237). London: Routledge.

Berry, K. (2008). The implementation of the NICE guidelines for schizophrenia: barriers to the implementation of psychological interventions and recommendations for the future. Psychology and Psychotherapy, 81, 419-436.

Berry, K., Barrowclough, C., \& Haddock, G. (2011). The role of expressed emotion in relationships between psychiatric staff and people with a diagnosis of psychosis: A review of the literature. Schizophrenia Bulletin, 37, 958-972. 
Berry, K. \& Wearden, A. (2008). Staff attachment styles: A pilot study investigating the influence of adult attachment styles on staff psychological mindedness and therapeutic relationships. Journal of Clinical Psychology, 64, 355363.

Berry, K. \& Wearden, A. (2009). A pilot study investigating the use of psychological formulations to modify psychiatric staff perceptions of service users with psychosis. Behavioural and Cognitive Psychotherapy, 37, 39-48.

Blomberg, A., Rautkallio, A. M., \& Uusitalo, P. (1998). Äänekäs kaaos - äänetön vihellys: Kielialuehavainnoista psykoositerapian rakenteisiin [A loud chaos - a silent whistle: From chaos to structures of psychotherapy of psychosis]. Perheterapia, 14 (3), 40-50.

Bola, J. R. (2005). Medication-free research in early episode schizophrenia: Evidence of long-term harm? Schizophrenia Bulletin, 27, 1-9.

Bola, J. R., Lehtinen, K., Aaltonen, J., Rakkolainen, V., Syvalahti, E., \& Lehtinen, V. (2006). Predicting medication-free treatment response in acute psychosis: Cross-validation from the Finnish Need-Adapted project. Journal of Nervous \& Mental Disease, 194, 732-739.

Borchers, P. (1999). (Avoin) milanolainen ratkaisukeskeinen moniääninen keskustelu itsen muiden kanssa [An (open) Milan approach solution focused polyphonic discussion with alter in ego]. Perheterapia, 15 (1), 4-24.

Borchers, P. (2009). Äänien viidakossa [In a jungle of voices]. Perheterapia, 25 (4), 34-37.

Borg, M., Karlsson, B., Tondora, J., \& Davidson, L. (2009). Implementing personcentered care in psychiatric rehabilitation: What does this involve? The Israel Journal of Psychiatry and Related Sciences, 46, 84-93.

Borgengren, M. (2006). Samforskning om vårdmöten [Co-research on therapy meetings]. In A. Wächter (Ed.), Samforskning - att lära av klienten, [Coresearch - learning from the clients] (pp. 157-188). Falun: Mareld.

Bracken, P., Khalfa, J., \& Thomas, P., (2007). Recent translations of Foucault on mental health. Current Opinion in Psychiatry, 20, 605-608.

Bracken, P. \& Thomas, P. (2001). Postpsychiatry: A new direction for mental health. British Medical Journal, 322, 724-727.

Bracken, P. \& Thomas, P. (2010). From Szasz to Foucault: On the role of critical psychiatry. Philosophy, Psychiatry \& Psychology, 17, 218-228.

Bracken, P., Thomas, P., Timimi, S., Asen, E., Behr, G., Beuster, C., Bhunnoo, S., Browne, I., Chhina, N., Double, D., Downer, S., Evans, C., Fernando, S., Garland, M. R., Hopkins, W., Huws, R., Johnson, B., Johnson, B., Middleton, H., Moldavsky, D., Moncrieff, J., Mullins, S., Nelki, J., Pizzo, M., Rodger, J., Smyth, M., Summerfield, D., Wallace, J., \& Yeomans, D. (2012). Psychiatry beyond the current paradigm. British Journal of Psychiatry, 201, 430-434.

Braithwaite, J. (2010). Between-group behaviour in health care: Gaps, edges, boundaries, disconnections, weak ties, spaces and holes. A systematic review. BMC Health Services Research, 10, 330. 
Buchanan, R. W. \& Keller, W. (2010). The 2009 schizophrenia PORT psychopharmacological treatment recommendations and summary statements. Schizophrenia Bulletin, 36, 71-93.

Burbach, F. R. (2013). Towards a systemic understanding of family emotional atmosphere and outcome after psychosis. In A. Gumley, A. Gillham, K. Taylor, \& M. Schwannauer (Eds.), Psychosis and emotions (pp. 116-35). London: Routledge.

Burr, V. (2004). Social constructionism (2nd edition). New York: Routledge.

Campbell, M., Byrne, R., \& Morrison, A. P. (2013). Discrimination about psychosis: Stigma, emotions and changing emotional attitudes about psychosis to improve outcomes. In A. Gumley, A. Gillham, K. Taylor, \& M. Schwannauer (Eds.), Psychosis and emotions (pp. 98-115). London: Routledge.

Cecchin, G. (1987). Hypothesizing, circularity, and neutrality revisited: An invitation to curiosity. Family Process, 26, 405-13.

Cegala, D. J., McNeilis, K. S., McGee, D. S., \& Jonas, A. P. (1995). A study of doctors' and patients' perceptions of information processing and communication competence during the medical interview. Health Communication, 7, 179-203.

Clements, J. \& Davies, E. (2013). Prevention of psychosis: Creating societies where more people flourish. In J. Read \& J. Dillon (Eds.), Models of madness: Psychological, social and biological approaches to psychosis (2nd edition) (pp. 295-304). London: Routledge.

Cullberg, J. (2005). Psykoosit: Kokoava näkökulma [Psychoses: An integrative perspective]. Helsinki: Therapeia-säätiö.

Cullberg, J., Levander, S., Holmqvist, R., Mattsson, M., \& Wieselgren, I. - M. (2002). One-year outcome in first episode psychosis patients in the Swedish Parachute project. Acta Psychiatrica Scandinavica, 106, 276-285.

Currie, A. (2011). Recovery, social inclusion and the practice of psychiatrists. Mental Health and Social Inclusion, 15, 143-150.

Cutting, L. P., Aakre, J. M., \& Docherty, N. M. (2006). Schizophrenic patients' perceptions of stress, expressed emotion, and sensitivity to criticism. Schizophrenia Bulletin, 32, 743-50.

Davidson, L. (2010). PORT through a recovery lens. Schizophrenia Bulletin, 36, 107-8.

De Jaegher, H., Di Paolo, E., \& Gallagher, S. (2010). Can social interaction constitute social cognition? Trends in Cognitive Sciences, 14, 441-447.

De Jaegher, H. \& Froese, T. (2009). On the role of social interaction in individual agency. Adaptive Behavior, 17, 444-460.

Deegan, P. E. \& Drake, R. E. (2006). Shared decision making and medication management in the recovery process. Psychiatric Services, 57, 1636-1639.

Dennis, A. M. \& Leach, C. (2007). Expressed emotion and burnout: The experience of staff caring for men with learning disability and psychosis in a medium secure setting. Journal of Psychiatric Mental Health Nursing, 14, 267-276. 
Dixon, L. B., Dickerson, F., Bellack, A. S., Bennett, M., Dickinson, D., Goldberg, R. W., Lehman, A., Tenhula, W. N., Calmes, C., Pasillas, R. M., Peer, J., Kreyenbuhl, J., \& Schizophrenia Patient Outcomes Research Team (PORT) (2010). The 2009 schizophrenia PORT psychosocial treatment recommendations and summary statements. Schizophrenia Bulletin, 36, 48-70.

Dreifus, C. (2008). A conversation with Nancy C. Andreasen: Using imaging to look at changes in the brain. Retrieved from http:/ / www.nytimes.com/ 2008/09/16/health/research/16conv.html?_r=0

Dudley, R., Siitarinen, J., James, I., \& Dodgson, G. (2009). What do people with psychosis think caused their psychosis? A Q methodology study. Behavioural \& Cognitive Psychotherapy, 37, 11-24.

Egan, T. \& Jaye, C. (2009). Communities of clinical practice: The social organization of clinical learning. Health, 13, 107-125.

Elizur, J. \& Minuchin, S. (1989). Institutionalizing madness: Families, therapy, and society. New York: Basic Books.

Elliott, R., Slatick, E., \& Urman, M. (2001). Qualitative change process research on psychotherapy: Alternative strategies. In J. Frommer \& D. L. Rennie (Eds.), Qualitative psychotherapy research: Methods and methodology (pp. 69111). Lengerich: Pabst Science Publishers.

Elwyn, G. \& Grol, R. (2000). Shared decision making and the concept of equipoise: The competences of involving patients in healthcare choices. British Journal of General Practice, 50, 892-899.

Engqvist, I. \& Nilsson, K. (2009). Psychiatric nurses' descriptions of women with postpartum psychosis and nurses' 'responses - an exploratory study in Sweden. Issues in Mental Health Nursing, 30, 23-30.

Engqvist, I. \& Nilsson, K. (2010). Nurses - psychiatrists' main collaborators when treating women with postpartum psychosis. Journal of Psychiatric Mental Health Nursing, 17, 494-502.

Erdos, B. Z. \& Hughes, D. H. (2001). A review of assaults by patients against staff at psychiatric emergency centers. Psychiatric Services, 52, 1175-1177.

Fadden, G., Birchwood, M., Jackson, C., \& Barton, K. (2005). Psychological therapies: Implementation in early intervention services. In J. F. M. Gleeson \& P. D. McGorry (Eds.), Psychological interventions in early psychosis: A treatment handbook (pp. 261-280). Hoboken, NJ: Wiley.

Finnish Medical Society Duodecim (2001). Skitsofrenian käypä hoito [Schizophrenia: Current care]. Duodecim, 117, 2640-2657.

Foucault, M. (1975). The birth of the clinic: An archaeology of medical perception. New York: Vintage Books.

Foucault, M. (1980). Tarkkailla ja rangaista [Discipline and punish: The birth of the prison]. Helsinki: Otava.

Frank, A. F. \& Gunderson, J. G. (1990). The role of the therapeutic alliance in the treatment of schizophrenia. Relationship to course and outcome. Archives of General Psychiatry, 47, 228-236.

Fuchs, T. (2002). The challenge of neuroscience: Psychiatry and phenomenology today. Psychopathology, 35, 319-326. 
Fuchs, T. (2005). Corporealized and disembodied minds: A phenomenological view of the body in melancholia and schizophrenia. Philosophy, Psychiatry, \& Psychology, 12, 95-107.

Fuchs, T. \& De Jaegher, H. (2009). Enactive intersubjectivity: Participatory sense-making and mutual incorporation. Phenomenology and the Cognitive Sciences, 8, 465-486.

Galeazzi, G. M., Mackinnon, A., \& Curci, P. (2007). Constraints perceived by psychiatrists working in community mental health services. Development and pilot study of a novel instrument. Community Mental Health Journal, 43, 609-618.

Galeazzi, G. M. \& Rigatelli, M. (2006). Views on psychosis and judgment of appropriateness of early interventions in pre-psychotic phase: A survey of members of the International Early Psychosis Association. Journal of Mental Health, 15, 569-576.

Geekie, J. \& Read, J. (2009). Making sense of madness: Contesting the meaning of schizophrenia. London: Routledge.

Gerson, R., Davidson, L., Booty, A., McGlashan, T., Malespina, D., Pincus, H. A., \& Corcoran, C. (2009). Families' experience with seeking treatment for recent-onset psychosis. Psychiatric Services, 60, 812-816.

Gleeson, J. F. M. \& McGorry, P. D. (Eds.) (2005). Psychological interventions in early psychosis: A treatment handbook (pp. 261-280). Hoboken, NJ: Wiley.

Goffman, E. (1961). Asylums: Essays on the social situations of mental patients and other inmates. New York: Anchor Books.

Graneheim, U. H. \& Lundman, B. (2004). Qualitative content analysis in nursing research: Concepts, procedures and measures to achieve trustworthiness. Nurse Education Today, 24, 105-112.

Griffiths, L. (2001). Categorising to exclude: The discursive construction of cases in community mental health teams. Sociology of Health $\mathcal{E}$ Illness, 23, 678700 .

Gromer, J. (2012). Need-Adapted and Open-Dialogue treatments: Empirically supported psychosocial interventions for schizophrenia and other psychotic disorders. Ethical Human Psychology and Psychiatry, 14, 162-177.

Guillemin, M. \& Gillam, L. (2004). Ethics, reflexivity, and "ethically important moments" in research. Qualitative Inquiry, 10, 261-280.

Haarakangas, K. (1997). Hoitokokouksen äänet: Dialoginen analyysi perhekeskeisen psykiatrisen hoitoprosessin hoitokokouskeskusteluista työryhmän toiminnan näkökulmasta [The voices in treatment meeting: A dialogical analysis of the treatment meeting conversations in family-centered psychiatric treatment process in regard to the team activity]. Jyväskylä Studies in Education, Psychology and Social Research, 130.

Haley, J. (1980). Leaving home: The therapy of disturbed young people. New York: McGraw-Hill.

Hall, S. (2003). Foucault: Power, knowledge and discourse. In M. Wetherell, S. Taylor, \& S. J. Yates (Eds.), Discourse theory and practice (pp. 72-81). London: Sage. 
Hardcastle, M., Kennard, D., Grandison, S., \& Fagin, L. (Eds.) (2007). Experiences of mental health in-patient care - narratives from service users, carers and professionals. London: Routledge.

Harrow, M., Jobe, T. H., \& Faull, R. N. (2012). Do all schizophrenia patients need antipsychotic treatment continuously throughout their lifetime? A 20-year longitudinal study. Psychological Medicine, 42, 2145-2155.

Haverkamp, B. E. (2005). Ethical perspectives on qualitative research in applied psychology. Journal of Counseling Psychology, 52, 146-155.

Henriksen, K. \& Hansen, E. H. (2004). The threatened self: General practitioners' self-perception in relation to prescribing medicine. Social Science $\mathcal{E}$ Medicine, 59, 47-55.

Herrman, H. (2002). The roles and relationships of psychiatrists and other service providers in mental health services. Australian \& New Zealand Journal of Psychiatry, 36, 75-80.

Hinshelwood, R. D. (2013). Suffering the impact: Psychosis and the professional caregiver. In A. Gumley, A. Gillham, K. Taylor \& M. Schwannauer (Eds.) Psychosis and emotions (pp. 84-97). London: Routledge.

Hirschfeld, R., Smith, J., \& Griffin, C. (2005). What do psychotic experiences mean for young men? A qualitative investigation. Psychology \& Psychotherapy: Theory, Research \& Practice, 78, 249-70.

Holma, J. M. (1999). The search for a narrative: Investigating acute psychosis and the need-adapted treatment model from the narrative viewpoint. Jyväskylä Studies in Education, Psychology and Social Research, 150.

Holmqvist, R. (1998). The influence of patient diagnosis and self-image on clinicians' feelings. Journal of Nervous \& Mental Disease, 186, 455-461.

Holmqvist, R. \& Armelius, B. (2006). Sources of psychiatric staff members' feelings towards patients and treatment outcome. Psychology and Psychotherapy: Theory, Research and Practice, 79, 571-584.

Hultsjo, S., Bertero, C., \& Hjelm, K. (2009). Foreign-born and Swedish-born families' perceptions of psychosis care. International Journal of Mental Health Nursing, 18, 62-71.

Huttunen, M. O. (2001). Käypä hoito ja käytäntö psykiatriassa [Practice guidelines and psychiatric treatment in practice]. Duodecim, 117, 2525-2526.

Iso-Koivisto, E. (2004). "Pois sieltä, ylös, takaisin" - ensimmäinen psykoosi kokemuksena ["Away from there, upwards, back again" - meaning given to the experience of first psychotic episode]. Turku: Annales Universitatis Turkuensis, C 218 .

Jacobsen, T. B. (2012). Involuntary treatment in Europe: Different countries, different practices. Current Opinion in Psychiatry, 25, 307-310.

Jacobson, N. \& Greenley, D. (2001). What is recovery? A conceptual model and explication. Psychiatric Services 52, 482-485.

Jimmieson, N. L. \& Gallagher, J. (2010). An investigation of the stress-buffering effects of social support in the occupational stress process as a function of team identification. Group Dynamics: Theory, Research, E Practice, 14, 350367. 
Jokinen, P. \& Pelkonen, M. (1996). Virikkeitä antava haastattelu (Stimulated recall interview) menetelmä käsitysten, kokemusten ja ajattelun tutkimiseen hoitotieteessä [Stimulated recall interview: A data gathering method for studying perception and experiences in nursing]. Hoitotiede, 8, 134-141.

Kaffman, M. (1984). Paranoid disorders: The core of truth behind the delusional system. International Journal of Family Therapy, 6, 220-232.

Kagan, N. (1969). Affect simulation in interpersonal process recall. Journal of Counseling Psychology, 16, 309-313.

Kampman, O. (2005). Hoitomyöntyvyys psyykenlääkkeitä käyttävillä [Patient compliance with psychiatric medications]. Suomen Lääkärilehti, 60, 12851289.

Karatza, H. \& Avdi, E. (2011). Shifts in subjectivity during the therapy for psychosis. Psychology and Psychotherapy: Theory, Research and Practice, 84, 214229.

Keränen, J. (1992). Avohoitoon ja sairaalahoitoon valikoituminen perhekeskeisessä psykiatrisessa hoitojärjestelmässä [The choice between outpatient and inpatient treatment in a family centered psychiatric treatment system]. Jyväskylä Studies in Education, Psychology and Social Research, 93.

Kissling, W. (2001). Who is interested in the quality of everyday psychiatric care? International Clinical Psychopharmacology, 16, 1-4.

Kissling, W. \& Leucht, S. (1999). Results of treatment of schizophrenia: Is the glass half full or half empty? International Clinical Psychopharmacology, 14, 11-14.

Kreyenbuhl, J., Buchanan, R. W., Dickerson, F. B., \& Dixon, L. B. (2010). The Schizophrenia Patient Outcomes Research Team (PORT): Updated treatment recommendations 2009. Schizophrenia Bulletin, 36, 94-103.

Kvale, S. (1996). InterViews - An Introduction to qualitative research interviewing. London: Sage.

Lääkintöhallitus (1988). Skitsofreniaprojekti 1981-1987. Skitsofrenian tutkimuksen, hoidon ja kuntoutuksen valtakunnallisen kehittämisohjelman loppuraportti [The Schizophrenia Project 1981-1987. Final report of the national programme of the study, treatment and rehabilitation of schizophrenic patients in Finland]. Helsinki: Lääkintöhallituksen opassarja nro 4.

Laitila, A. (2004). Dimensions of expertise in family therapeutic process. Jyväskylä Studies in Education, Psychology and Social Research, 237.

Laitila, A. (2009). The expertise question revisited: Horizontal and vertical expertise. Contemporary Family Therapy, 31, 239-250.

Lambert, M. J. (2005). Early response in psychotherapy: Further evidence for the importance of common factors rather than "placebo effects". Journal of Clinical Psychology, 61, 855-869.

Lambert, M. J. \& Barley, D. E. (2002). Research summary on the therapeutic relationship and psychotherapy outcome. Psychotherapy, 38, 17-32.

Lambert, M. J., Whipple, J. L., Vermeersch, D. A., Smart, D. W., Hawkins, E. J., Nielsen, S. L., \& Goates, M. (2002). Enhancing psychotherapy outcomes 
via providing feedback on client progress: A replication. Clinical Psychology \& Psychotherapy, 9, 91-103.

Langlands, R. L. \& Kitchener, B. A. (2008). First aid recommendations for psychosis: using the Delphi method to gain consensus between mental health consumers, carers, and clinicians. Schizophrenia Bulletin, 34, 435-443.

Lehtinen, K. (1993). Family therapy and schizophrenia in public mental health care. Turku: Annales Universitatis Turkuensis, D 106.

Leiman, M. (2006). Psykoterapiamuodot ja käypä hoito. [Psychotherapy methods and current care]. Duodecim, 122, 703-704.

Leiman, M. \& Stiles, W. B. (2001). Dialogical sequence analysis and the zone of proximal development as conceptual enhancements to the assimilation model: The case of Jan revisited. Psychotherapy Research, 11, 311-330.

Lepping, P., Sambhi, R. S., Whittington, R., Lane, S., \& Poole, R. (2011). Clinical relevance of findings in trials of antipsychotics: Systematic review. British Journal of Psychiatry, 198, 341-345.

Lester, H. \& Gask, L. (2006). Delivering mental care for patients with serious mental illness or promoting a collaborative model of recovery? British Journal of Psychiatry, 188, 401-402.

Linell, P. (1998). Approaching dialogue: Talk, interaction and contexts in dialogical perspectives. Amsterdam: John Benjamins.

Lingard, L. \& DeVito, I. (2002). Team communications in the operating room: Talk patterns, sites of tension, and implications for novices. Academic Medicine, 77, 232-237.

Lingard, L. \& Espin, S. (2002). Forming professional identities in the health care team: Discursive constructions of the 'other' in the operating room. Medical Education, 36, 728-34.

Lobban, F., Barrowclough, C., \& Jones, S. (2003). A review of the role of illness models in severe mental illness. Clinical Psychology Review, 23, 171-196.

Lönnqvist, J., Henriksson, M., Marttunen, M., \& Partonen, T. (2011). Psykiatria [Psychiatry]. Helsinki: Duodecim.

Loughland, C. M., Lawrence, G., Allen, J., Hunter, M., Lewin, T. J., Oud, N. E., \& Carr, V. J. (2009). Aggression and trauma experiences among carerrelatives of people with psychosis. Social Psychiatry And Psychiatric Epidemiology, 44, 1031-1040.

Louhiala, P. \& Hemilä, H. (2005). Näyttöön perustuva lääketiede - hyvä renki mutta huono isäntä [Evidence-based medicine - good employee but bad employer]. Duodecim, 121, 1317-1325.

Luborsky, L., Diguer, L., Seligman, D. A., Rosenthal, R., Krause, E. D., Johnson, S., Halperin, G., Bishop, M., Berman, J. S., \& Schweizer, E. (1999). The Researcher's own therapy allegiances: A "wild card" in comparisons of treatment efficacy. Clinical Psychology: Science and Practice, 6, 95-106.

Lysaker, P. H., Buck, K. D., \& Hammoud, K. (2007). Psychotherapy and schizophrenia: An analysis of requirements of individual psychotherapy with persons who experience manifestly barren or empty selves. Psychology and Psychotherapy: Theory, Research and Practice, 80, 377-387. 
Macpherson, R. \& Lerescu, T. (2008). The relationships between user, carer and staff perceptions of need in an assertive outreach team. Journal of Mental Health, 17, 452-461.

Macpherson, R. \& Slade, M. (2003). Staff and patient assessments of need in an epidemiologically representative sample of patients with psychosis - staff and patient assessments of need. Social Psychiatry \& Psychiatric Epidemiolo$g y, 38,662-667$.

Marangos-Frost, S. \& Wells, D. (2000). Psychiatric nurses' thoughts and feelings about restraint use: A decision dilemma. Journal of Advanced Nursing, 31, 362-369.

Markova, I. (2006). On 'the inner alter' in dialogue. International Journal for Dialogical Science, 1, 125-147.

Markova, I., Linell, P., Grossen, M. \& Salazar Orvig, A. (2007). Dialogue in focus groups - exploring socially shared knowledge. London: Equinox.

May, R. (2005). Making Sense of Psychotic Experience and Working Towards Recovery. In J. F. M. Gleeson \& P. D. McGorry (Eds.) Psychological interventions in early psychosis: A treatment handbook (pp. 245-260). Hoboken, NJ: Wiley.

McCabe, R., Heath, C., Burns, T., \& Priebe, S. (2002). Engagement of patients with psychosis in the consultation: conversation analytic study. British Medical Journal, 325, 1148-51.

McCabe, R. \& Priebe, S. (2004). The therapeutic relationship in the treatment of severe mental illness: A review of methods and findings. The International Journal of Social Psychiatry, 50, 115-128.

McCann, T. V., Lubman, D. I., \& Clark, E. (2011). Responding to stigma: Firsttime caregivers of young people with first-episode psychosis. Psychiatric Services, 62, 548-550.

McCann, T. V., Lubman, D. I., \& Clark, E. (2012). Primary caregivers' satisfaction with clinicians' response to them as informal carers of young people with first-episode psychosis: a qualitative study. Journal of Clinical Nursing, 21, 224-231.

McGorry, P. D. (2005). An Overview of the Background and Scope for Psychological Interventions in Early Psychosis. In J. F. M. Gleeson \& P. D. McGorry (Eds.) Psychological interventions in early psychosis: A treatment handbook (pp. 1-22). Hoboken, NJ: Wiley..

McGorry, P. D. \& McConville, S. B. (1999). Insight in psychosis: An elusive target. Comprehensive Psychiatry, 40, 131-142.

McGrail, K. A. \& Gardner, K. (2009). "What is found there": Qualitative analysis of physician-nurse collaboration stories. Journal of General Internal Medicine, 24, 198-204.

McLeod, H. J. \& Hogbin, B. (2002). Changing staff attitudes and empathy for working with people with psychosis. Behavioural and Cognitive Psychotherapy, 30, 459-470.

McNamee, S. \& Gergen, K., J. (Eds.) (1999). Relational responsibility: Resources for sustainable dialogue. Thousand Oaks, CA: Sage. 
Messer, S. B. \& Wampold, B. E. (2002). Let's face facts: Common factors are more potent than specific therapy ingredients. Clinical Psychology: Science and Practice, 9, 21-25.

Miller, S. D., Duncan, B. L., Sorrell, R., \& Brown, G. S. (2005). The partners for change outcome management system. Journal of Clinical Psychology, 61, 199-208.

Moritz, S., Rietschel, L., Veckenstedt, R., Bohn, F., Schneider, B. C., Lincoln, T. M., \& Karow, A. (2013). The other side of "madness": Frequencies of positive and ambivalent attitudes towards prominent positive symptoms in psychosis. Psychosis. Published online, doi: 10.1080/17522439.2013.865137.

Morran, D. K., Kurpius, D. J., \& Brack, G. (1989). Empirical investigation of counselor self-talk categories. Journal of Counseling Psychology, 36, 505-510.

Morrison, A. P., Hutton, P., Shiers, D., \& Turkington, D. (2012). Antipsychotics: Is it time to introduce patient choice? The British Journal of Psychiatry, 201, 83-84.

Mosher, L. \& Bola, J. (2013). Non-hospital, non-medication interventions in firstepisode psychosis. In J. Read \& J. Dillon (Eds.) Models of Madness: Psychological, social and biological approaches to psychosis (2nd edition) (pp. 361377). London: Routledge.

Mosher, L., Gosden, R., \& Beder, S. (2013). Drug companies and 'schizophrenia': Unbridled capitalism meets madness. In J. Read \& J. Dillon (Eds.) Models of Madness: Psychological, social and biological approaches to psychosis (2nd edition) (pp. 125-139). London: Routledge.

NIMHE (2005). NIMHE Guiding Statement on Recovery. Retrieved from http://studymore.org.uk/nimherec.pdf.

Noiseux, S., Tribble St-Cyr, D., Corin, E., St-Hilaire, P., Morissette, R., Leclerc, C., Fleury, D., Vigneault, D., \& Gagnier, F. (2010). The process of recovery of people with mental illness: The perspectives of patients, family members and care providers: Part 1. BMC Health Services Research, 10, 161-175.

Norcross, J. C. \& Wampold, B. E. (2011a). What works for whom: Tailoring psychotherapy to the person. Journal of Clinical Psychology, 67, 127-132.

Norcross, J. C. \& Wampold, B. E. (2011b). Evidence-based therapy relationships: Research conclusions and clinical practices. Psychotherapy, 48, 98-102.

Norman, I. J. \& Peck, E. (1999). Working together in adult community mental health services: An inter-professional dialogue. Journal of Mental Health, 8, 217-230.

Omérov, M. \& Wistedt, B. (2004). Violence and threats of violence within psychiatric care - a comparison of staff and patient experience of the same incident. Nordic Journal of Psychiatry, 58, 363-368.

Onyett, S. \& Muijen, M. (1997). Job satisfaction and burnout among members of community mental health teams. Journal of Mental Health, 6, 55-66.

Oud, M. J. T., Schuling, J., Slooff, C. J., Groenier, K. H., Dekker, J. H., \& Meyboom-de Jong, B. (2009). Care for patients with severe mental illness: The general practitioner's role perspective. BMC Family Practice, 10, 29-37. 
Oud, M. J. T., Schuling, J., Slooff, C. J. \& Jong, B. M., (2007). How do General Practitioners experience providing care for their psychotic patients? BMC Family Practice, 8, 37-44.

Patel, S. R., Bakken, S., \& Ruland, C. (2008). Recent advances in shared decision making for mental health. Current Opinion in Psychiatry, 21, 606-612.

Peck, E. \& Norman, I. J. (1999). Working together in adult community mental health services: Exploring inter-professional role relations. Journal of Mental Health, 8, 231-243.

Penn, P. \& Frankfurt, M. (1994). Creating a participant text: Writing, multiple voices, narrative multiplicity. Family Process, 33, 217-231.

Piippo, J. (2008). Trust, autonomy and safety at integrated network- and familyoriented model for co-operation: A qualitative study. Jyväskylä Studies in Education, Psychology and Social Research, 347.

Priebe, S., Burns, T., \& Craig, T. K. J. (2013). The future of academic psychiatry may be social. The British Journal of Psychiatry, 202, 319-320.

Priebe, S., McCabe, R., Bullenkamp, J., Hansson, L., Lauber, C., Martinez-Leal, R., Rössler, W., Salize, H., Svensson, B., Torres-Gonzales, F., van den Brink, R., Wiersma, D., \& Wright, D. J. (2007). Structured patient-clinician communication and 1-year outcome in community mental healthcare: Cluster randomised controlled trial. The British Journal of Psychiatry, 191, 420-426.

Priebe, S., Richardson, M., Cooney, M., Adedeji, O., \& McCabe, R. (2011). Does the therapeutic relationship predict outcomes of psychiatric treatment in patients with psychosis? A systematic review. Psychotherapy and Psychosomatics, 80, 70-77.

Quirk, A., Chaplin, R., Lelliott, P., \& Seale, C. (2012). How pressure is applied in shared decisions about antipsychotic medication: A conversation analytic study of psychiatric outpatient consultations. Sociology of Health $\mathcal{E}$ Illness, 34, 95-113.

Raboch, J., Kalisová, L., Nawka, A., Kitzlerová, E., Onchev, G., Karastergiou, A., Magliano, L., Dembinskas, A., Kiejna, A., Torres-Gonzales, F., Kjellin, L., Priebe, S., \& Kallert, T. (2010). Use of coercive measures during involuntary hospitalization: Findings from ten european countries. Psychiatric Services, 61, 1012-1017.

Rakkolainen, V., Lehtinen, K., \& Alanen, Y. O. (1991). Need-adapted treatment of schizophrenic processes: The essential role of family-centered therapy meetings. Contemporary Family Therapy, 13, 573-582.

Rao, H. \& Luty, J. (2009). A study of stigmatized attitudes towards people with mental health problems among health professionals. Journal Psychiatric Mental Health Nursing, 16, 279-284.

Rautiainen, E. (2010). Co-construction and collaboration in couple therapy for depression. Jyväskylä Studies in Education, Psychology and Social Research, 396.

Read, J. 2008. Schizophrenia, drug companies and the internet. Social science $\mathcal{E}$ medicine, 66, 99-109. 
Read, J. (2013a). Does 'schizophrenia" exist? Reliability and validity. In J. Read \& J. Dillon (Eds.), Models of madness: Psychological, social and biological approaches to psychosis (2nd edition) (pp. 47-61). London: Routledge.

Read, J. (2013b). The Invention of 'schizophrenia': Kraepelin and Bleuler. In J. Read \& J. Dillon (Eds.), Models of madness: Psychological, social and biological approaches to psychosis (2nd edition) (pp. 20-33). London: Routledge.

Read, J. (2013c). Childhood adversity and psychosis: From heredity to certainty. In J. Read \& J. Dillon (Eds.), Models of madness: Psychological, social and biological approaches to psychosis (2nd edition) (pp. 249-275). London: Routledge.

Read, J. \& Beavan, V. (2013). Gender and psychosis. In J. Read \& J. Dillon (Eds.), Models of madness: Psychological, social and biological approaches to psychosis (2nd edition) (pp. 210-219). London: Routledge,.

Read, J. \& Cain, A. (2013). A literature review and meta-analysis of drug company-funded mental health websites. Acta Psychiatrica Scandinavica, 128, 422-433.

Read, J. \& Dillon, J. (Eds.) (2013). Models of madness: Psychological, social and biological approaches to psychosis (2nd edition). London: Routledge.

Read, J., Haslam, N., \& Magliano, L. (2013). Prejudice, stigma and 'schizophrenia': The role of biogenetic ideology. In J. Read \& J. Dillon (Eds.), Models of madness: Psychological, social and biological approaches to psychosis (2nd edition) (pp. 157-177). London: Routledge.

Read, J., Johnstone, L., \& Taitimu, M. (2013). Psychosis, poverty and ethnicity. In J. Read \& J. Dillon (Eds.), Models of madness: Psychological, social and biological approaches to psychosis (2nd edition) (pp. 191-209). London: Routledge.

Read, J. \& Magliano, L. (2012). The subjective experience and beliefs of relatives of people who experience psychosis. In J. Geekie, P. Randal, D. Lampshire \& J. Read (Eds.), Experiencing psychosis: Personal and professional perspectives (pp. 207-216). London: Routledge.

Read, J., Magliano, L., \& Beavan, V. (2013). Public beliefs about the causes of 'schizophrenia'. In J. Read \& J. Dillon (Eds.), Models of madness: Psychological, social and biological approaches to psychosis (2nd edition) (pp. 143-156). London: Routledge.

Read, J., Mosher, L. R., \& Bentall, R. P. (Eds.) (2004). Models of madness: Psychological, social and biological approaches to schizophrenia. London: Routledge.

Read, J. \& Seymour, F. (2013). Psychosis and families: Intergenerational parenting problems. In J. Read \& J. Dillon (Eds.), Models of madness: Psychological, social and biological approaches to psychosis (2nd edition) (pp. 276-291). London: Routledge.

Rees, H. \& Harrison, G. (2002). Attitudes of psychiatrists to evidence-based guidelines: A questionnaire survey. Psychiatric Bulletin, 26, 421-424.

Rober, P. (2005). Explorations in dialogical family therapy: The concept of the therapist's inner conversation. Universiteit Gent, Faculteit Psychologie en Pedagogische Wetenschaffen. 
Rober, P. \& De Corte, K. (2008). What's on the therapist's mind? A grounded theory analysis of family therapist reflections during individual therapy sessions. Psychotherapy Research. 18, 48-57.

Rober, P., Seikkula, J., \& Laitila, A. (2010). Dialogical analysis of storytelling in the family therapeutic encounter. Human Systems, 21, 27-49.

Roberts, G. \& Wolfson, P. (2004). The rediscovery of recovery: Open to all. British Journal of Psychiatry, 10, 37-48.

Roberts, M. (2005). The production of the psychiatric subject: Power, knowledge and Michel Foucault. Nursing Philosophy, 6, 33-42.

Robertson, M. D. \& Walter, G. (2008). Many faces of the dual-role dilemma in psychiatric ethics. Australian and New Zealand Journal of Psychiatry, 42, 228235.

Rose, D., Thornicroft, G., \& Slade, M. (2006). Who decides what evidence is? Developing a multiple perspectives paradigm in mental health. Acta Psychiatrica Scandinavica, Suppl. 429, 109-114.

Rosen, A. (2006). The community psychiatrist of the future. Current Opinion in Psychiatry, 19, 380-388.

Rosenhan, D. L. (1973). On being sane in insane places. Science, 179, 250-258.

Rosenstein, A. H. (2002). Nurse-physician relationships: Impact on nurse satisfaction and retention. American Journal of Nursing, 102, 26-34.

Rossberg, J. I. \& Friis, S. (2003). Staff members' emotional reactions to aggressive and suicidal behavior of inpatients. Psychiatric Services, 54, 1388-1394.

Saari, M. (2002). Psykoosityöryhmä vaikeiden mielenterveyshäiriöiden hoidossa Kainuussa vuosina 1992 - 1996 [Psychosis team in treatment of severe mental disorders in Kainuu in 1992-1996]. Oulu: Acta Universitatis Ouluensis, D, 665.

Saba, G., Wong, S., Schillinger, D., Fernandez, A., Somkin, C., Wilson, C., \& Grumbach, K. (2006). Shared decision making and the experience of partnership in primary care. Annals of Family Medicine, 4, 54-62.

Safran, D. G. \& Beckman, H. (2006). Organizational dimensions of relationshipcentered care: Theory, evidence, and practice. Journal of General Internal Medicine, 21, S9-S15.

Salgado, J. \& Hermans, H. J. M. (2005). The return of subjectivity: From a multiplicity of selves to the dialogical self. E-Journal of Applied Psychology, 1, 313.

Schmalenberg, C. \& Rapp, D. (2005). Excellence through evidence: Securing collegial/collaborative nurse-physician relationships, part 1. Journal of Nursing Administration, 35, 450-458.

Schomerus, G., Schwahn, C., Holzinger, A., Corrigan, P. W., Grabe, H. J., Carta, M. G., \& Angermeyer, M. C. (2012). Evolution of public attitudes about mental illness: A systematic review and meta-analysis. Acta Psychiatrica Scandinavica, 125, 440-452.

Schön, D. A. (1983). The reflective practitioner - How professionals think in action. New York: Basic Books. 
Seale, C., Chaplin, R., Lelliott, P., \& Quirk, A. (2006). Sharing decisions in consultations involving anti-psychotic medication: A qualitative study of psychiatrists' experiences. Social Science \& Medicine, 62, 2861-2873.

Seale, C., Chaplin, R., Lelliott, P., \& Quirk, A. (2007). Antipsychotic medication, sedation and mental clouding: An observational study of psychiatric consultations. Social Science \& Medicine, 65, 698-711.

Seikkula, J. (1991). Perheen ja sairaalan rajasysteemi potilaan sosiaalisessa verkostossa [The family-hospital boundary system in the social network]. Jyväskylä Studies in Education, Psychology and Social Research, 80.

Seikkula, J. (2002). Open dialogues with good and poor outcomes for psychotic crises: Examples from families with violence. Journal of Marital E Family Therapy, 28, 263-274.

Seikkula, J. (2005). Kuinka tutkimusasetelmat ja käytetyt tutkimusmenetelmät muokkaavat tulokset psykoosihoidon tuloksellisuustutkimuksissa? [How the arrangements and methods used in research modify results in the outcome research of the treatment of psychosis] In K. Hartikainen \& J. Aaltonen (Eds.), Näyttöön perustuva psykoterapia [Evidence based psychotherapy] (pp. 101-112). Jyväskylän yliopisto, Psykoterapian opetus- ja tutkimusklinikka.

Seikkula, J. (2008). Inner and outer voices in the present moment of family and network therapy. Journal of Family Therapy, 30, 478-491.

Seikkula, J., Aaltonen, J., Alakare, B., Haarakangas, K., Keranen, J., \& Lehtinen, K. (2006). Five-year experience of first-episode nonaffective psychosis in open-dialogue approach: Treatment principles, follow-up outcomes, and two case studies. Psychotherapy Research, 16, 214-228.

Seikkula, J., Alakare, B., \& Aaltonen, J. (2011). The comprehensive opendialogue approach in Western Lapland: II. Long-term stability of acute psychosis outcomes in advanced community care. Psychosis, 3, 192-204.

Seikkula, J., Alakare, B., Holma, J., Rasinkangas, A., \& Lehtinen, V. (2003). Open Dialogue approach: Treatment principles and preliminary results of a twoyear follow-up on first episode schizophrenia. Ethical Human Sciences $\mathcal{E}$ Services, 5, 163-182.

Seikkula, J. \& Arnkil, T. E. (2005). Dialoginen verkostotyö [Dialogical meetigs in social networks]. Helsinki: Tammi.

Seikkula, J. \& Olson, M. E. (2003). The open dialogue approach to acute psychosis: Its poetics and micropolitics. Family Process 42, 403-418.

Selvini, M. P., Boscolo, L., Cecchin, G., \& Prata, G. (1980). Hypothesizing - circularity - neutrality: Three guidelines for the conductor of the session. Family Process, 19, 3-12.

Servais, L. M. \& Saunders, S. M. (2007). Clinical psychologists' perceptions of persons with mental illness. Professional Psychology: Research \& Practice, 38, 214-219.

Sheehan, K. A. (2009). Compulsory treatment in psychiatry. Current Opinion in Psychiatry, 22, 582-586. 
Silverman, D. (2005). Doing qualitative research: A practical handbook. London: Sage.

Sin, J., Moone, N., \& Harris, P. (2008). Siblings of individuals with first-episode psychosis: Understanding their experiences and needs. Journal of Psychosocial Nursing and Mental Health Services, 46, 33-40.

Sorvaniemi, M. \& Kampman, O. (2000). Hoitomyöntyvyys skitsofreniassa ja mielialahäiriössä. [Compliance with treatment in schizophrenia and mood disorders]. Duodecim, 116, 277-284.

Sprenkle, D. H., Davis, S., D., \& Lebow, J., L. (2009). Common factors in couple and family therapy: The overlooked foundation for effective practice. New York: Guilford.

Stern, S., Doolan, M., Staples, E., Szmukler, G. L., \& Eisler, I. (1999). Disruption and reconstruction: Narrative insights into the experience of family members caring for a relative diagnosed with serious mental illness. Family Process, 38, 355-368.

Stevenson, C. \& Cutcliffe, J. (2006). Problematizing special observation in psychiatry: Foucault, archaeology, genealogy, discourse and power/knowledge. Journal of Psychiatric \& Mental Health Nursing, 13, 713-721.

Suchman, A. L. (2006a). Control and relation: Two foundational values and their consequences. Journal of Interprofessional Care, 20, 3-11.

Suchman, A. L. (2006b). A new theoretical foundation for relationship-centered care: Complex responsive processes of relating. Journal of General Internal Medicine, 21, S40-S44.

Szasz, T. S. (1960). The myth of mental illness. American Psychologist, 15, 113118.

Szasz, T. (2011). The myth of mental illness: 50 years later. Psychiatrist, 35, 179182.

Tähkä, V. (1982). Psykoterapian perusteet psykoanalyyttisen teorian pohjalta [Principles of psychotherapy - a psychoanalytic perspective]. Porvoo: WSOY.

Tanskanen, S., Morant, N., Hinton, M., Lloyd-Evans, B., Crosby, M., Killaspy, H., Raine, R., Pilling, S., \& Johnson, S. (2011). Service user and carer experiences of seeking help for a first episode of psychosis: A UK qualitative study. BMC Psychiatry, 11, 157-168.

The Schizophrenia Update Guideline Development Group and National Collaborating Centre for Mental Health (2010). Schizophrenia: Core interventions in the treatment and management of schizophrenia in adults in primary and secondary care - updated edition. London: The British Psychological Society and The Royal College of Psychiatrists.

Thornicroft, G., Brohan, E., Rose, D., Sartorius, N., \& Leese, M. (2009). Global pattern of experienced and anticipated discrimination against people with schizophrenia: A cross-sectional survey. The Lancet, 373, 408-415.

Topor, A. (2004). Vad hjälper? Vägar till återhämtning från svåra psykiska problem. [What helps? Roads to recovery from severe mental illness] Stockholm: Natur och kultur. 
Torjuul, K., Nordam, A., \& Sorlie, V. (2005). Ethical challenges in surgery as narrated by practicing surgeons. BMC Medical Ethics, 6, 2 .

Totman, J., Hundt, G. L., Wearn, E., Paul, M., \& Johnson, S. (2011). Factors affecting staff morale on inpatient mental health wards in England: A qualitative investigation. BMC Psychiatry, 11, 68-78.

Treanor, L., Lobban, F., \& Barrowclough, C. (2013). Relatives' responses to psychosis: An exploratory investigation of low expressed emotion relatives. Psychology and Psychotherapy, 86, 197-211.

Tyrer, P. (2012). From the Editor's desk. The British Journal of Psychiatry, 201, 168-168.

Tzeng, W. \& Lipson, J. G. (2005). Health professionals' perspectives of suicide in Taiwan. Issues in Mental Health Nursing, 26, 451-463.

van Os, J., Altamura, A. C., Bobes, J., Gerlach, J., Hellewell, J. S. E., Kasper, S., Naber, D., \& Robert, P. (2004). Evaluation of the Two-Way Communication Checklist as a clinical intervention. The British Journal of Psychiatry, 184, 79-83.

van Os, J. \& Kapur, S. (2009). Schizophrenia. The Lancet, 374, 635-645.

Volosinov, V. (1990). Kielen dialogisuus. Marxismi ja kielifilosofia. [Marxism and the Philosophy of Language]. Tampere: Vastapaino.

Vuokila-Oikkonen, P. (2002). Akuutin psykiatrisen osastohoidon yhteistyöneuvottelun keskustelussa rakentuvat kertomukset [Narratives unfolding in cooperative team meetings in acute psychiatric care]. Oulu: Acta Universitatis Ouluensis, D 704.

Vygotski, L. S. (1982). Ajattelu ja kieli [Thought and language]. Espoo: Weilin+ Göös.

Vygotsky, L. S. (1978). Mind in society: The development of higher psychological processes. Cambridge: Harvard University.

Wahlbeck, K. (2005). Psykoterapiatutkimuksen laatukriteerit Cochranenäkökulmasta [Qualitative standards of psychotherapy research from the Cochrane perspective]. In K. Hartikainen \& J. Aaltonen (Eds.), Näyttöön perustuva psykoterapia [Evidence based psychotherapy] (pp. 32-43). Jyväskylän yliopisto, Psykoterapian opetus- ja tutkimusklinikka.

Wampold, B. E. (2005). Establishing specificity in psychotherapy scientifically: Design and evidence issues. Clinical Psychology: Science and Practice, 12, 194-197.

Wampold, B. E. \& Bhati, K. S. (2004). Attending to the omissions: A historical examination of evidence-based practice movements. Professional Psychology: Research and Practice, 35, 563-570.

Wampold, B. E. \& Brown, G. S. (2005). Estimating variability in outcomes attributable to therapists: A naturalistic study of outcomes in managed care. Journal of Consulting and Clinical Psychology, 73, 914-923.

Wazana, A. (2000). Physicians and the pharmaceutical industry: Is a gift ever just a gift? The Journal of the American Medical Association, 283, 373-80.

Whitaker, R. (2003). Mad in America: Bad science, bad medicine, and the enduring mistreatment of the mentally ill. New York: Basic Books. 
White, M. \& Epston, D. 1990. Narrative means to therapeutic ends. New York: Norton.

Working group appointed by the Finnish Medical Society Duodecim and the Finnish Psychiatric Association (2013). Skitsofrenia: Käypä hoito -suositus [Schizophrenia: Current care]. Retrieved from http://www.kaypahoito.fi/ web/kh/suositukset/suositus?id=hoi35050.

Wortham, S. (2001). Narratives in action: A strategy for research and analysis. New York: Teachers College.

Wynn, R. (2003). Staff's attitudes to the use of restraint and seclusion in a Norwegian university psychiatric hospital. Nordic Journal of Psychiatry, 57, 453459.

Young, R. A. (2004). Introduction: Constructivism and social constructionism in the career field. Journal of Vocational Behavior, 64, 373-388.

Zipursky, R. B., Reilly, T. J., \& Murray, R. M. (2013). The myth of schizophrenia as a progressive brain disease. Schizophrenia Bulletin, 39, 1363-1372. 


\title{
ORIGINAL PUBLICATIONS
}

\section{PSYCHIATRISTS' INNER DIALOGUES CONCERNING WORKMATES DURING NEED ADAPTED TREATMENT OF PSYCHOSIS}

\author{
by \\ Pekka Borchers, Jaakko Seikkula, \& Klaus Lehtinen, 2013 \\ Psychosis, 5, 60-70 \\ Reproduced with kind permission by Taylor \& Francis Group.
}


Background: In the Need-Adapted approach (NAA) decisions are made in therapy meetings together with all relevant parties; this poses a professional challenge to psychiatrists.

Aims: To describe psychiatrists' inner dialogues concerning their workmates in treatment meetings.

Methods: Using videos of co-research interviews, stimulated-recall interviews with eight psychiatrists were conducted and transcribed verbatim. The material was analyzed using an adapted form of dialogical analysis, focusing on voices and positioning.

Results: The psychiatrists took actions in the treatment situation not only as professionals, but also as individuals who had their own characteristics, and individual relationships with their coworkers.

Conclusions: Professionals as individuals and the quality of clinician-clinician relationships have an impact on treatment, and these aspects should be taken into account in practice, in education, and in future research.

Keywords: psychosis; psychiatrists; inner dialogue; teamwork

\section{Introduction}

As well as being painful to the patients and their social network, psychotic crises constitute a challenge to professionals. For several years we have been working as family-therapy professionals (the first and the third author having trained as psychiatrists, and the second author as a clinical psychologist), working in psychosis teams and following the NeedAdapted approach (NAA) (Alanen, 2009). Within our practice we have observed the difficulties of integrating all the aspects that need to be taken into account. In NAA the psychiatrist always works as part of the team, and treatment aspects are discussed and decided in therapy meetings together with the patients, family members, and staff. Psychiatrists - most of whom have no specialized relationship-focused training - have to be able to co-operate with the patient, the families, and workmates, while at the same time taking on social and medical responsibilities. In 2005, at the time when the first author began to study psychiatrists' inner dialogues in therapy meetings within the NAA treatment of firstepisode psychosis, it appeared that (at least in Finland) there were confusing differences in the guidelines for the treatment of psychosis (Finnish Medical Society Duodecim / Current Care, 2001; Gleeson \& McGorry, 2004; Read, Mosher, \& Bentall, 2004; Seikkula, Alakare, Holma, Rasinkangas, \& Lehtinen, 2003; Topor, 2004). The aim of the research was to describe the inner dialogues psychiatrists have. The study described in this paper aimed to characterize psychiatrists' inner dialogues concerning their workmates; the focus was on the personal aspects of the professionals in question. 


\section{Inner dialogues}

The inner guiding images of staff members have been studied in NAA, with the aim of describing how the treatment process of schizophrenia is conducted in a multiprofessional team (Aaltonen \& Räkköläinen, 1994) The shared image evolves as each member of the staff brings her/his own inner dialogue concerning the treatment into a team discussion. Each participant in the meeting participates in the discussion - the outer dialogue - and at the same time has many thoughts about what is discussed - the inner dialogue. In understanding notions of dialogue we have found the ideas of Mikhail Bakhtin (1984) and his co-workers to be particularly useful. Rober (2005) describes inner conversation as a negotiation between the experiencing self and the professional self of the therapist. In therapy meetings, professionals have to consider whether their emotions and associations are in any way connected to the treatment, and whether they should be said aloud. In a dialogue, as it continues, our thoughts and emotions are transformed: we begin to compare and evaluate our different responses. Voice and positioning are concepts which are used to catch the complexity of dialogical phenomena. Voice refers to the speaker or actor, and positioning to the position from which she/he is speaking or acting. Every participant in a dialogue - even in a single utterance speaks in different voices and positions her/him self in different ways, according to the context.

\section{Professionals' inner dialogues and relationships}

Within the literature, the concept of relationship-centered care (RCC) - which is associated mainly with somatic and general medicine - comes close to the focus of this study. RCC highlights the importance of all relationships and their impact on health outcomes; it further focuses on the personhood of all the participants, their affects and emotions, the context of reciprocal influence, and the moral value of genuine relationships (Beach, 2006; Safran, 2006; Suchman, 2006). The only study we have found regarding teamwork in psychosis (Engqvist, 2010) concluded that collaboration between nurses and psychiatrists in postpartum psychosis is based on confidence in the nurses' competence.

\section{Participants and methods}

\section{The research process}

A qualitative multiple case study approach was chosen, and the regional ethics committees gave the study positive statements. The interviews were conducted between August 2007 and 
January 2009. Eight psychiatrists from three different geographical locations were asked for their informed consent. For research purposes, the inner dialogue is a theoretical concept: in fact, we are forced to rely on the outer dialogue, meaning what is said aloud about the inner dialogue. To create a context in which the inner dialogue could be studied, the psychiatrists were interviewed together with the patient, family members, and the fellow workers within the team, following the co-research interview method (CR-I) (Andersen, 1997). The CR-I is a method which allows the professionals and the clients to evaluate the treatment process conjointly, with the help of a third party. The research process continued with a stimulatedrecall interview procedure (STR-I) (Elliott, Slatick, \& Urman, 2001): segments of the videotapes of the first interviews were used to help the psychiatrists to recall their thoughts and feelings during that first interview.

\section{The interviewees and the interview process}

Out of the eight psychiatrists (seven females, one male, aged 36-61 years) six had lengthy experience in psychiatry. Two were undergoing their psychiatric training, and four were family therapists. The participants' experience of psychotic patients ranged from one to 26 years. Three of the psychiatrists were in charge only of patients' inpatient care; two were responsible for outpatient care, but also contributed to inpatient care. The remaining psychiatrists worked in outpatient care. In two interviews the psychiatrists from both the inpatient and outpatient care centers were present. Two psychiatrists were interviewed twice.

In seven CR-I's only one co-worker was present, in the eighth there were three. Eight of the participating co-workers were nurses and two were psychologists.

The patients consisted of four females and four males (age range 19-56 years). Their diagnosis (of psychosis) had been operational for a maximum of two years. On four occasions the patient's mother took part in the interview, on two occasions the mother took part together with a sister, and on one occasion a sister took part. One patient did not want his family to contribute to the treatment, and this patient's family was not interviewed.

Both interviews lasted approximately 1.5 hours. The STR-I took place one to five days after the CR-I. The researcher selected from the CR-I, choosing the parts to be viewed in the STR-I.

\section{Material}

Each STR-I was transcribed verbatim. The researcher then viewed the videotapes several times, and at the same time read the transcriptions. Thereafter, the researcher divided the transcriptions into topical episodes (Linell, 1998). In total, 139 topical episodes were formed. 
To categorize the material, summaries of the topical episodes were made. Five themes emerged; thus the interviewees were observed to speak about 1) persons who were involved in the treatment process; 2) the psychiatric syndromes and the symptoms; 3 ) the treatment and opinions or stances concerning the therapies; 4) institutional factors; and 5) the research situation.

\section{Method of analysis}

Topical episodes in which the interviewees referred to their workmates were examined more closely with an adaptation of dialogical analysis.(Markova, Linell, Grossen, \& Salazar Orvig, 2007; Rober, Seikkula, \& Laitila, 2010). The voices and positioning were divided into categories, and these were used to write the results as a story containing various personal aspects of the professionals' inner dialogue, as it related to their workmates' impact on the psychosis treatment process. All meaningful decisions concerning the interviews and analysis during the entire research process were discussed at least four times per year during group meetings supervised by the second author.

A credibility assessment of the final analysis was conducted by the second author, in collaboration with three doctoral students. Each of the four went through two different thematic episodes to name all the voices and ways of positioning observable in the interviewee's talk about her/his workmates. Altogether 134 remarks were made relating to 33 speech lines. Only two remarks differed from the researcher's own analysis. Following the researcher's clarification, the four credibility assessors were able to understand the differences, which were seen to stem from the researcher's greater familiarity with the material.

\section{Results}

The interviewees spoke about their workmates in 60 of the 139 thematic episodes. Four main voice categories and eight main positioning categories were created. The voice categories were 1) voices of professionals, 2) voices of patients and family members, 3 ) institutional voices, and 4) voices outside psychiatry. The positioning categories were: 1) ourselves as members of staff or professionals, 2) the interviewee as an individual in relation to the professionals involved, 3) a conventional occupational relationship, 4) the psychiatrist as leader, 5) respect as a position, 6) critical evaluation as a position, 7) ambivalence as a position, and 8) miscellaneous positioning. The categories are presented below with extracts; here one can see different personal aspects of the psychiatrists' inner dialogue related their 
workmates as having a possible impact on the treatment. There are a number of different voices and ways of positioning in every extract, but (with the exception of the category of institutional voices) each extract is chosen to exemplify one category. The interview extracts have been translated from Finnish to English, shortened, and simplified. Names, occupations and details have been altered.

\section{"If this conversation was individual psychotherapy"}

There were various kinds of tensions between the professional and personal aspects of the interviewees, and these were manifested in speech about workmates. The first extract shows how the problematic features of the psychiatrist hers/himself can have an impact.

1. If this conversation was individual psychotherapy, I might talk about this at length. I have to struggle to control my behavior when I feel anger towards my workmates. With this psychologist, I feel a bit at a loss. Generally I just interrupt her abruptly. But these interruptions are a bad idea if we think of the good of the patient.

The second extract shows how a patient's comment can challenge externality. A middle-aged female psychiatrist was astonished at a young male patient's view that the staff could serve as a role model for him concerning his drinking habits. Even though the interviewee tries to emphasize the gap between the professionals and the patients, the personal lives of professionals are strongly present in her speech.

If we had a man in his thirties working here, I could see him as an example to the patient. But we are all women. We are in no way a temperance association, but that's not our patients' business. Then again, if he only knew the truth about the drinking habits of the nursing staff. I'm not speaking about myselfthough in my youth I used to go to bars quite a bit. If he ever ran into a member of staff in one of those bars, what would happen then? He might think, what's the big deal, if they drink, why should I be sober?

Because of the emotions of workmates, there seemed to be a risk of exaggerated caution and consideration, even concerning obvious shortcomings. 
The interviewees found it difficult to believe co-workers' - or clients' - critical comments concerning professionals whom they themselves felt to be trustworthy. As we can see in the next extract, this dilemma can elicit even suspicions.

I asked the psychiatrist in the outpatient clinic if the public-health nurse had been in contact with them. I didn't get any proper answer. I have my doubts that the nurse made the phone call to the young social worker, who didn't recall it. There is nothing mentioned in the documents either. In spite of that, I believe that the nurse did make a phone call to the outpatient clinic.

\section{"He used racist talk about killing niggers"}

A patient's young age or some special features, for example a threat of violence, amplified the emotions of the professionals, and this made it harder to reach reasonable decisions about treatment. The emotional challenges in the treatment had a tendency to turn out arguing between professionals. care. They were angry. It's quite unusual that the young mother of a small child is committed to hospital. I was very irritated when I asked them about the heavy medication. The conversation we had, it was unconventional and uncomfortable.

6. Our team was conflicted. I felt like a total traitor, as I had been talking to my
senior psychiatrist. The patient had planned to get a gun, and had used racist
talk about killing niggers; there was heavy drinking and some fist fights with
total strangers in a bar. The police arrested him.

The criticisms and demands from family members were painful to hear. Comments of this kind could lead to increased criticism of workmates. In the next extract the interviewee, a member of the outpatient team, comments family member's astonishment concerning patient's sleepiness in the hospital ward.

7. I thought he [the patient] had such a heavy medication only for the first night. It sounds that it was actually several days. We had disagreements with the staff in the ward, but hearing this, made me feel anger.

However, as in the extract below, demands from family members could lead to a kind of unification of the professionals. There was then a danger that the patient could be left alone between two groups - the professional as "us," and the family members as "them." 
the realities of the situation. Of course we try to help. But she herself is responsible for her life, we are treating her psychiatric illness.

\section{"Why haven't you done anything in the outpatient care"}

Institutional voices are seen in most of the extracts, for example regarding the boundaries between professionals and clients (extract 2), inpatient and outpatient care $(5,7)$, medical documents (4), the leadership, hierarchy, and medical responsibility $(6,8,11,12,16)$, and ethical dilemmas and rules in institutions $(10,13,17)$.

\section{"There was a downpour and a very strong wind"}

The voices observed mostly came from the professional setting. The following extract demonstrates how the voice of the environment is used as a means to describe intense frustration, caused partly by a co-worker.

9.

When we left the patient's house and opened the door, there was downpour and a very strong wind (laughter). We tried to walk forward. It felt like it was actually impossible to get out of there.

\section{"It's difficult to apologize for someone else"}

One important detail concerned the interviewees' relationship to shared institutional responsibility. In the next extract the interviewee tries to find a way to respond as a person in an institutional setting where someone else has failed.

10. She refused to discuss it further, because nobody had had a conversation with her when she arrived at the hospital. Should we somehow have made an apology as the family did? As this is a system with many different people in it, it's difficult to apologize for someone else.

\section{"I was so alone"}

Medical responsibility was associated with feelings of loneliness. In the following excerpt the interviewee describes his feelings concerning team discussions about ordering medicine.

11. Basically it's a decision you have to do yourself alone. Occasionally you can get some support from the senior psychiatrists, which is extremely pleasant. If there are major problems in the treatment (laughter), you are not able to find proper medication (laughter) and a team member speaks out of turn-yes, you can say it's stressful now and then.

An experienced workmate's lack of support had been exceptionally difficult for an inexperienced psychiatrist. 
time - things she had played down before. So I hadn't overreacted, nor am I stupid. Actually things could have ended badly.

\section{"How one can make better use of them"}

The next extract indicates the dilemma between professionals as persons and as part of the institution. Respect towards nurses had in some measure an instrumental value for maximizing effectiveness, and this can involve an ethical challenge for the interviewee.

13. This is a delicate matter. I have noticed that you can't ever be too careful about treating the nurses respectfully. One has to admit the thought isn't so fine. It isn't an absolute value that they are to be treated with respect and appreciation. The truth is that this is how one can make better use of them, to put it in an unpleasant way.

\section{"I don't want to be disrespectful"}

Almost without exception the interviewees at least tried to speak about their workmates as persons who deserved understanding, empathy and esteem, or politeness. If there were disagreements, the interviewees tried to understand their workmates.

14. The communication with him is quite difficult. I don't want to be disrespectful. He has very many good features, but it's very hard to give him feedback. Like all of us, he is sometimes tense, because of too much work or some other reason.

\section{"I feel ashamed"}

A different kind of critical evaluation was accompanied by strong emotion on the part of the interviewee. In the next extract, a patient's interruption (during the psychologist's account of recent confusing and frightening incidents involving the patient) is reported as having affected the interviewee's feelings towards a co-worker.

15. When the patient says that he has started to suspect his mental health, in a way he is giving you a starting point. Many kinds of meaningful conversations are possible. But the psychologist is bewitched by his own voice and continues with his account, which is going nowhere. I feel ashamed.

Respect and critical evaluation were interconnected: when the workmates were involved in a challenging task, it was difficult to utter critical thoughts aloud. 


\title{
"It just stuck in my mind"
}

The interviews - and also the conversations between professionals during the treatment were to a considerable extent emotionally loaded situations for the interviewees. In the following extract, when the interviewee is commenting on a patient's view concerning manipulation, he seems to respond as a person to his own words. The interviewee's admiration for his workmate's straightforwardness and boldness changed - probably because he was saying it aloud in front someone - to a sort of shame. This is observable in the paralinguistic communication and in the last sentence.

17.

$$
\begin{aligned}
& \text { It was sort of manipulation, when we confronted her with the terms, how to get } \\
& \text { out of the hospital. When she refused to sign the form dealing with her } \\
& \text { property, which was kept in a locked closet, her personal nurse just said, okay, } \\
& \text { next time I'm on the shift is a week from now, we'll return to this question then } \\
& \text { [uneasy laughter]. After that she did sign all of a sudden [uneasy laughter]. It } \\
& \text { just stuck in my mind [uneasy laughter]. }
\end{aligned}
$$

\section{"He has enough worries and sorrows himself"}

If the workmates had problems in their personal lives, the interviewees were not merely extremely careful not to say anything critical; by taking a therapeutic attitude they to some extent positioned their workmates as patients.

18.

\author{
Sometimes we made our way to work together in the same train. He has \\ enough worries and sorrows himself. I even recommended him to make an \\ appointment with a colleague. You just want so spare him. Inevitably these \\ kinds of things have an effect.
}

\section{Discussion}

The aim of this study was to characterize psychiatrists' inner dialogues concerning their workmates during Need-Adapted teamwork. Undoubtedly, teamwork in the treatment of psychosis was seen as beneficial, or even self-evident; for example, case-specific teams and psychiatrists' discussion with experienced workmates were recognized as important ways to share and delimit responsibility. Nevertheless, the interviewees' speech concerning their workmates was related to challenges and problems. The interview protocol had a tendency to develop into a critical evaluation of the treatment. In line with the literature concerning relationship-centered care (Beach, 2006; Suchman, 2006), this study shows how the psychiatrists took actions in the treatment situation not only as professionals, but also as 
persons - individuals who had their own characteristics and emotional reactions, and genuine relationships with their co-workers.

Though we were unable to trace methodologically similar qualitative studies, parallel findings have been discovered in various fields of medicine: the physician's role in the welfare of their workmates is prominent (Jimmieson, 2010), interprofessional collaboration is crucially important for novices, and challenges in professional collaboration are associated with crises in patient care and affects (McGrail, 2009), and with the boundaries in health care organizations (Braithwaite, 2010).

The majority of the few papers concerning workmate relationships in psychiatry do not focus on the personal characteristics of professionals; however, the following are relevant to the findings of this study. Psychiatrists' respect for and trust in workmates' competence is essential (Engqvist, 2010). There can be a contradiction between the views of psychiatrists and others concerning the power of the psychiatrist (Peck, 1999). It can be harmful for recovery if there is excessive focus on avoiding failure and blame (Peck, 1999) and if the individual responsibility of professionals remains vague (Herrman, 2002). Norman (1999) saw a strong adherence to an uni-professional culture. Nevertheless, our interviewees had hopes of mutual responsibility with experienced workmates from other professions, and such an attitude will tend to place an emphasis on the quality of NAA teamwork. The central clinical guidelines of NAA include a psychotherapeutic attitude - referring to the intention of achieving an understanding going beyond mere diagnostic categorization - and genuine multiprofessional discussion.

In NAA the main forum for discussing and deciding about the treatment is the therapy meeting. Here, group conversation between the patient, the family and the multiprofessional team shows significant differences compared to a more structured conversation based on different treatment orientations. We believe that for example psychoeducation involves a risk of underestimating human experience. Therapy meetings are professional scenes full of human thoughts, experiences, and emotions (Haarakangas, 1997; Seikkula, 2002). Psychotic reactions should be seen as attempts to make sense of one's experience and to cope with experiences that are so difficult that it has not been possible to construct a rational spoken narrative. Therapy meetings are thus a forum for constructing and negotiating a positive sense of identity (Seikkula, 2002). According to Haarakangas it is essential to have a reflective attitude towards both the outer and inner dialogue in treatment meetings. The members of the team should ask themselves whether their thoughts are based on what has appeared in the discussion, or whether they are irrelevant in the context. In his 
study, the reflecting that occurred between team members - or self-reflection on bodily feelings - was a working method by which the personal voices of team members could become material for the inner reflection of the clients (Haarakangas, 1997). In this process of helping service users, the experiences and emotions of psychiatrists and other staff can be resource - or a barrier. NAA constitutes a humanistic and democratic approach, one that is based on horizontal knowledge, dialogue, and polyphony. At the same time, NAA is an opportunity for professionals to achieve greater understanding and respect, both in relation to each other and to their clients. However, as this study demonstrates, the challenges are substantial. In the Finnish NAA tradition, multiprofessional (family) therapy training programs have been implemented to help staff to be able to meet these challenges (Aaltonen, Seikkula, \& Lehtinen, 2011).

\section{Study limitations}

The proportion of family therapists in the sample was high as compared to that among psychiatrists in general. The interviewees described their inner dialogue within CR-I, and not during an actual therapy meeting. Furthermore, the researcher in the study was by no means a neutral observer; indeed, it is intended that future analysis will focus on the impact of the researcher.

\section{Conclusions}

Professionals as individuals and also clinician-clinician relationships have an impact on the quality of dialogue, and this may well be influential in the outcome of psychosis (Seikkula, 2002); hence these aspects should be taken into account in practice, in education, and in future research. The current evidence-based tradition, which emphasizes firmly-structured approaches (for example psycho-education), cannot take into account the phenomena which exist in a real-life situation, and which were seen in this study. The training and supervising of psychiatrists should enhance their self knowledge, their dialogical skills, and their ability to tolerate uncertainty in the kinds of complicated relationships that exist within the multiprofessional processes that occur during the treatment of psychosis.

\section{References}


Aaltonen, J., \& Räkköläinen, V. (1994). The shared image guiding the treatment process -A precondition for integration of the treatment of schizophrenia. British Journal of Psychiatry, $164,97-102$.

Aaltonen, J., Seikkula, J., \& Lehtinen, K. (2011). The comprehensive open-dialogue approach in western Lapland: I. the incidence of non-affective psychosis and prodromal states. Psychosis, 3(3), 179-191.

Alanen, Y. O. (2009). Towards a more humanistic psychiatry: Development of need-adapted treatment of schizophrenia group psychoses. Psychosis: Psychological, Social and Integrative Approaches, 1(2), 156.

Andersen, T. (1997). Researching client-therapist relationships: A collaborative study for informing therapy. Journal of Systemic Therapies, 16(2), 125-133.

Bakhtin, M. M. (1984). In Emerson C. (Ed.), Problems of Dostoevsky's poetics (C. Emerson Trans.). Minneapolis: University of Minnesota Press.

Beach, M. C. (2006). Relationship-centered care. A constructive reframing. J Gen Intern Med, 21 Suppl 1, S3.

Braithwaite, J. (2010). Between-group behaviour in health care: Gaps, edges, boundaries, disconnections, weak ties, spaces and holes. A systematic review. BMC Health Services Research, 10(1), 330.

Elliott, R., Slatick, E., \& Urman, M. (2001). Qualitative change process research on psychotherapy: Alternative strategies. In J. Frommer, \& D. L. Rennie (Eds.), Qualitative psychotherapy research: Methods and methodology. (pp. 69-111). Lengerich, Germany: Pabst Science Publishers. 
Engqvist, I. (2010). Nurses--psychiatrists' main collaborators when treating women with postpartum psychosis. J Psychiatr Ment Health Nurs, 17(6), 494.

Finnish Medical Society Duodecim / Current Care. (2001). Skitsofrenian käypä hoito. Lääketieteellinen Aikakausikirja Duodecim, (117), 2640-2657.

Gleeson, J. F. M., \& McGorry, P. D. (Eds.). (2004). Psychological interventions in early psychosis: A treatment handbook. England: John Wiley \& Sons.

Haarakangas, K. (1997). Hoitokokouksen äänet. Dialoginen analyysi perhekeskeisen psykiatrisen hoitoprosessin hoitokokouskeskusteluista työryhmän toiminnan näkökulmasta. [The voices on treatment meeting. A dialogical analysis of the treatment meeting conversation in family-centered psychiatric treatment process in regard to the team activity.] In Finnish with English summary. (Jyväskylä Studies in Education, Psychology and Social Research, 130 ed.). Jyväskylä: University of Jyväskylä.

Herrman, H. (2002). The roles and relationships of psychiatrists and other service providers in mental health services. Australian \& New Zealand Journal of Psychiatry, 36(1), 75-80.

Jimmieson, N. L. (2010). An investigation of the stress-buffering effects of social support in the occupational stress process as a function of team identification. Group Dynamics: Theory, Research, \& Practice, 14(4), 350-367.

Linell, P. (1998). Approaching dialogue: Talk, interaction and contexts in dialogical perspectives. Philadelphia; Amsterdam: John Benjamins Publishing.

Markova, I., Linell, P., Grossen, M., \& Salazar Orvig, A. (2007). Dialogue in focus groups exploring socially shared knowledge. London: Equinox. 
McGrail, K. A. (2009). "What is found there": Qualitative analysis of physician-nurse collaboration stories. J Gen Intern Med, 24(2), 198.

Norman, I. J. (1999). Working together in adult community mental health services: An interprofessional dialogue. Journal of Mental Health. Electronic; 8(3), 217-230.

Peck, E. (1999). Working together in adult community mental health services: Exploring inter-professional role relations. Journal of Mental Health. Electronic; 8(3), 231-243.

Read, J., Mosher, L. R., \& Bentall, R. P. (Eds.). (2004). Models of madness - psychological, social and biological approaches to schizophrenia. . London: Routledge.

Rober, P. (2005). Explorations in dialogical family therapy: The concept of the therapist's inner conversation. Universiteit Gent, Faculteit Psychologie en Pedagogische Wetenschaffen).

Rober, P., Seikkula, J., \& Laitila, A. (2010). Dialogical analysis of storytelling in the family therapeutic encounter. Human Systems: The Journal of Therapy, Consultation and Training, 21(1), 27-49.

Safran, D. G. (2006). Organizational dimensions of relationship-centered care: Theory, evidence, and practice. Journal of General Internal Medicine. Electronic; 21, S9-S15.

Seikkula, J. (2002). Open dialogues with good and poor outcomes for psychotic crises: Examples from families with violence. Journal of Marital \& Family Therapy, 28(3), 263274. 
Seikkula, J., Alakare, B., Holma, J., Rasinkangas, A., \& Lehtinen, V. (2003). Open dialogue approach: Treatment principles and preliminary results of a two-year follow-up on first episode schizophrenia. Ethical Human Sciences \& Services, 5(3), 163-182.

Suchman, A. L. (2006). A new theoretical foundation for relationship-centered care:

Complex responsive processes of relating. Journal of General Internal Medicine. Electronic; 21, S40-S44.

Topor, A. (2004). Vad hjälper? Vägar till återhämtning från svåra psykiska problem. [What helps? Roads to recovery from severe mental illness.] In Swedish. Stockholm: Natur och kultur. 


\title{
II
}

\section{PSYCHOSIS, NEED ADAPTED TREATMENT, AND PSYCHIA- TRISTS' AGENCY}

\author{
by \\ Pekka Borchers, Jaakko Seikkula, \& Klaus Lehtinen, 2014 \\ Psychosis, 6, 27-37 \\ Reproduced with kind permission by Taylor \& Francis Group.
}


Background: In the Need-Adapted approach (NAA) therapy meetings are a deliberate effort to bring all meaningful parties and views to a common discussion prior to decisions; this constitutes a challenge for psychiatrists' agency.

Aims: To describe how psychiatrists see their agency in NAA.

Methods: Using videos of co-research interviews, stimulated-recall interviews of ten interviewees were conducted and transcribed verbatim. The material was analyzed via an adapted dialogical-narrative analytical method.

Results: Institutional forces were experienced as having an enormous impact on psychiatrists' agency, especially in the inpatient setting, reducing professional creativity. In the outpatient setting, psychiatrists who attended also hospital care were the most able to follow the principles of NAA and those who took part only in outpatient treatment had a tendency to adopt the position of medical consultants.

Conclusions: The ability of psychiatrists to have agency in the language used with the clients is an underrated issue. The interview methods used in the research could be utilized in practice.

Keywords: psychosis; need adapted treatment; inner dialogue; psychiatrists’ agency

\section{Introduction}

The ongoing research project aims to shed light on challenges linked to the inner dialogues of psychiatrists whose clinical practice is based on the Need-Adapted approach (NAA) to the treatment of psychosis (Alanen, 2009). In NAA the psychiatrist works as part of a team, and treatment aspects are discussed and decided on together with the patients, family members, and staff during therapy meetings (Rakkolainen, 1991). They are guided by psychotherapeutic attitude to find a common understanding of what has happened, and to evaluate the real and changing needs of the patients and the family. In addition, concrete treatment plans are drawn up and continuously revised within therapy meetings. The purpose is to work with the experiences of the clients, and to avoid the dominance of a medical perspective that might involve unnecessary treatments. In NAA the psychiatrist should be able to hear and consider all the voices present in the therapy meeting, including the scientific and institutional voices of the profession. The fictitious case story below illustrates these challenges.

\section{In a jungle of voices}

The patient has experienced voices and delusions. However, he has maintained his working capacity. From time to time he shows understanding of his condition. The patients and his parents, the psychiatrist, a nurse from the ward, and a psychologist from the outpatient clinic 
take part in the therapy meeting. The mother is wondering what could possibly have happened. The father is requesting medication. The nurse is suggesting hospital treatment, but the psychologist would prefer an outpatient setting. The managers have emphasized that psychiatrist should base their decisions on the current guidelines for evidence-based treatment (Finnish Medical Society Duodecim / Current Care, 2008) and try to get patients to take neuroleptics. However, many researchers have expressed criticism of the predominant view in biological psychiatry (Read, Mosher, \& Bentall, 2004). Starting medication might mean involuntarily treatment in the hospital. The patient doesn't even wish to take a brief period of sick leave. If the professionals cannot succeed in creating a working alliance with the patient now, the situation may become even harder in the future. The psychiatrist would prefer to apply a need-adapted treatment model. Some international early-psychosis studies have come close to the need-adapted treatment tradition, though they place an emphasis on cognitive therapy and family psychoeducation (Gleeson \& McGorry, 2004). The open dialogue approach (Seikkula, 2011) would make it possible to have a constructive conversation in order to gain some understanding of the psychotic crisis. Should the psychiatrist ask the patient to say more about his strange experiences, or about the moments when he acknowledges his symptoms? Or should he focus on the resources of the patient, emphasizing health as the results from research on recovery indicate (Topor, 2004). The psychiatrist is not convinced that the other participants within the therapy meeting are paying attention to the strengths of the patient. He has legal responsibility. Hospitalization could relieve the insecure situation, but this would mean starting the patient on medication. Inpatient treatment often leads to difficulties in co-operation, even to traumatic experiences, and the patient and his natural network lose their agency. In outpatient care there isn't enough resources to meet the family every day, though that might be the best procedure. Can the patient and family tolerate the uncertainty and take the responsibility? The father is starting to become nervous, as the psychiatrist is not making any decisions.

\section{Agency, the dual-role dilemma, shared decision making, and NAA}

In social constructionist literature the concept of agency is defined as the capacity to make choices and to act upon them (Burr, 2004). There has been a substantial body of research in this tradition, including a study on patients' agency in acute psychosis and NAA (Holma, 1999). Unfortunately we have been unable to find studies with direct relevance to the present paper. The concept of double agency, as used in psychiatric literature, has a slightly different 
nuance. It refers to psychiatrists' conflicting obligations to their patients and to a powerful third party. Nevertheless, although the moral tensions implicit in a dual role (Austin, 2008; Robertson, 2008) form one important aspect of the present study, in contrast to the more traditional psychiatry within NAA such tensions are not seen as phenomena to be avoided. Therapy meetings constitute a deliberate effort to bring all meaningful parties and views together within a common discussion.

Some papers concerning shared decision making (Patel, 2008; Quirk, 2012; Seale, 2006) have highlighted psychiatrists' agency with regard to psychosis, focusing on patients' and psychiatrists' negotiations on treatment plans. Although the therapy meetings of NAA described here are indeed forums for shared decision making, they differ from the more traditional approaches as their main aim is psychotherapeutic and they are multiprofessional family discussions.

\section{Participants and methods}

\section{Research process and methods}

The eight psychiatrists in this study - two of whom attended two different interviews - were first interviewed together with the patient, family members, and coworkers, following the coresearch interview method (CR-I) (Andersen, 1997). Thereafter they were interviewed using segments of the videotapes of the first interviews applying a stimulated-recall method (STRI) (Elliott, Slatick, \& Urman, 2001). The interviewees were asked to describe thoughts, emotions and experiences they had in the specific section of the CR-I they saw from the video. The STR-I's were conducted individually, or as a twosome in the case of two interviews in which psychiatrists from both in- and outpatient care were present. Out of the ten interviewees, three were responsible solely for inpatient care. Three out of the seven who were responsible for outpatient care also participated in inpatient treatment. The entire study process is described in more detail in a separate article (Borchers, Seikkula, \& Lehtinen, 2012).

The transcripts of the STR-I's were studied via an adapted form of dialogical-narrative analysis (Rober, Seikkula, \& Laitila, 2010; Wortham, 2001), focusing on voices, addressees, and positioning. Voice refers to the speaker or actor, the addressee to the person to whom one is speaking, or the person who is being acted upon, and positioning to the position from which one is speaking or acting. In this analysis only those addressees who were referred to 
in a context indicated by reported speech (some other situation than the ongoing STR-I) were included and positioning refers to the perspective from which the psychiatrists look at their own agency. Altogether the analytic concepts (voice, addressee and positioning) were used as tools to get detailed descriptions how the psychiatrists in their own narratives see their agency and also what does their manners of using words tell about their positioning towards agency.

All meaningful decisions concerning the interviews and analysis during the entire research process were discussed at least four times per year during group meetings supervised by the second author. A credibility assessment of the final analysis was conducted by the second author, in collaboration with two doctoral students. After the primary researcher (P.B.) had clarified the concepts, each of the three went through two different thematic episodes in order to identify the voices, addressees, and forms of positioning. Altogether 90 identifications were made. Only one identification regarding positioning differed from the researcher's own analysis.

\section{Results}

We present our material that appeared to have clinical relevance. We shall first describe what the three different analytic concepts indicate, with regard to how the psychiatrists saw their agency. Thereafter we shall present the more or less common findings, and finally consider the effects produced by different settings. The interview extracts have been translated from Finnish to English, and simplified. Names, and details have been altered. The word client is used to refer to the patients, and their family members.

\section{What the analytic concepts indicate}

\section{Voices}

The voices of the professionals had a tendency to fuse with institutional voices. Thus, hospitals or outpatient clinics became agents who, rather than functioning as the professionals within them, became entities that took care of the treatment. It could be said that the inpatient unit per se actually had emotions.

1. I suppose it was a challenging incident for the ward also, quite exceptional for a single parent father to be committed to a psychiatric hospital.

The institutional tone "contaminated" the voices: the speech about normality, health and trust referred to the opposites - pathology, disability, and suspicion. The institutional forces of psychiatry had silenced the personal voices of the patient: the voices of health and 
normality were used referring mainly to the time before the patient entered psychiatry. Moreover, although family members, and especially siblings and friends brought with them the voices of everyday life, the people concerned were drawn into the category of close relatives of the patient rather than that of persons with their own interests. On the other hand using institutional phrases such as therapy meeting the psychiatrists, their coworkers, and the clients were put together within a kind of "us," seen as having a common interest.

\section{Addressees}

Addressees were used of all but one interviewee as verbal resources e.g. to express emotionally difficult parts of their internal dialogue. In the following extract, the interviewee quotes the managers, who have accused her team of inadequacy.

2. $\quad$ There is need for a proper psychosis team for the area. But we hear constantly:

"Why don't you do anything? How come you have fewer appointments than the other units?" They don't understand the differences between having a therapy meeting in a psychotic crisis and consulting a group of patients in order to write prescriptions.

When describing e.g. their disappointments about treatment failures the psychiatrists quoted occasionally to a hypothetical interaction which never happened.

\section{Positionings}

The interviewees positioned themselves towards their agency on three different levels, the first two of which are relevant to the clinical perspective of this article: 1) the storytelling event, this being the interactional context (i.e. the interview) within which the speaker utters something; 2) the narrated event described by the utterance (Wortham, 2001), and 3 ) the present moment, meaning that in articulating their thoughts, the interviewees simultaneously positioned themselves in relation to their own words, within the same utterance.

In the storytelling event the interviewees searched for words describing their emotions, shared their confusing experiences, and co-constructed a coherent narrative in such a way as to strengthen their feeling of agency. They also evaluated the treatment.

3. As I heard [in CR-I] he was medicated involuntarily so often I became even more irritated. When we had a quarrel with the hospital ward, I was thinking: let them handle it, I won't come here another time. That wasn't constructive. I should have attended the therapy meetings more often. 
The narrated events most often dealt with the treatment of the patient or the CR-I, but also e.g. personal issues.

4.

\begin{abstract}
The patient being openly racist is exceptionally difficult for me. I have lived in South Africa and I became familiar with apartheid. It's incomprehensible. Right from the start of assembling the case-specific team, I wondered if I could skip this background. The patient is entitled to proper treatment.
\end{abstract}

\title{
Common features
}

The most important choices were present in the interviewees' inner dialogues. At best they were grounded on the aim of increasing hope and empowering the clients. Active listening made it possible to hear clients' therapeutic proposals, resources, and processes of recovery, but also frightening issues. All the interviewees had experiences of losing their agency mostly as a response to a strong emotion such as fear. .

5. After he threatened me, I said to him: "There is the door, get out! Do you know what zero tolerance is? We follow it." Situations like this provoke affects. Though it was partly done on purpose, it wasn't reasonable behavior on my side either.

Taking account of clients' feelings or intentional therapeutic purposes, the interviewees considered what parts of their inner dialogue it was safe and meaningful to utter aloud, and what words and therapeutic orientations were appropriate.

6.

$$
\begin{aligned}
& \text { We could have told them more about schizophrenia spectrum disorders. But I } \\
& \text { wanted to give a more optimistic and comprehensible story. We should avoid } \\
& \text { using these diagnoses that can have negative effects on the prognosis. I myself } \\
& \text { have pushed some patients close to suicide by talking about schizophrenia. }
\end{aligned}
$$

Though serious effort was more important than success, all the psychiatrists reevaluated their past views and actions, or planned new measures.

7.

$$
\begin{aligned}
& \text { Leena [patient] is verbally extremely talented. Her responses are occasionally } \\
& \text { insulting. Staying quiet to preserve at least some kind of relationship has } \\
& \text { become an automatic reaction. Maybe it's time to start to discuss difficult } \\
& \text { issues and put one's own emotions into words. }
\end{aligned}
$$

Achieving a coherent narrative to calm down disturbing thoughts and emotions was so important that there was a risk of creating a pathological story or moralistic assessments of the clients - at times ignore the actual facts. 
Though facing critical views was difficult, the patient's siblings managed to phrase their criticism in a useful manner. Often the interviewees ended up in a position of ambivalence, located between defending themselves and self-criticism.

Discussion with colleagues and trustworthy coworkers and previous experience with psychosis emerged as resources contributing to agency. It was seen as important to adjust the treatment approach to the resources. Though some psychiatrists were confused about their dual role the participation of family members in the treatment was considered to be important. Positive feedback from clients was felt to be important. The feeling of responsibility was experienced as burdensome, but was a basis of agency.

The positioning taken by the psychiatrists was influenced also by personal features.

8.

For my generation this way of blaming parents is quite disturbing. I was even more annoyed when the father didn't respond. That's why I started to defend the father.

\section{Effects of different settings}

\section{The inpatient setting}

The psychiatrists responsible for inpatient treatment seldom used addressees as resources, and never hypothetical situations. They often gave thought to their agency with regard to involuntary commitment and compared to other settings had a stronger tendency to focus on pathology and symptoms. In spite of the big differences between the interviewees there was a clear risk of the "total institutions" phenomenon (Goffman, 1961), i.e. of institutional forces capturing human agency.

9. If the patient behaves in the way ordered, uses permissions as decided, doesn't cause any disturbances, and takes medication, patients are considered fit to be in society and are released to outpatient care.

The spirit in a psychiatric hospital made the staff to fantasize risks that might threaten their patients; avoidance of essential uncertainty was a hindrance to the process of recovery. The inpatient setting reduced hope, and it increased the frustration and cynicism of the interviewees. The team was seen as essential, but at the same time, it muddled the psychiatrists' experiences of their responsibility. 


\section{The outpatient setting}

The possibility that the patient would leave outpatient care led the psychiatrists to avoid important delicate matters.

The psychiatrists taking part in both outpatient and inpatient treatment These interviewees were able to use voices connected with many emotionally significant memories from specific treatment situations.

10.
The mother told us that the police had arrested Matti [the patient] for something he knew nothing about. It was unbelievable. I was shocked. We sat with the family for over two hours and were almost as upset as they were.

Shared experiences with the clients reinforced feelings of empathy and understanding and facilitated reflective thinking. This setting forced the psychiatrists to try to find a way to collaborate with the clients.

11. If involuntary commitment is needed, I prefer to make the referral myself. Then we can discuss it openly in therapy meetings. In my experience it doesn't break trust.

Given local treatment principles, including a family orientation, were felt in the same time as challenging and as a basis of agency. The psychiatrists in this group tended to analyze in detail the reasons for the possible failures, to emphasize their limited expertise, and to see the need for continuous learning from the clients. Becoming too closely connected with the clients was seen as a threat to the professionals' agency. This group was the only one to give consideration to efforts to keep the dose of neuroleptics minimal.

\section{Psychiatrists taking part only in outpatient care}

The psychiatrists in this group positioned themselves as medical consultants for the team. Their agency was focused on supporting nurses, who were the main professional agents, and organizing a treatment system - taking account of resources - that would be optimal for the treatment of psychosis. The stance of medical specialty sometimes collided with clients' holistic expectations.

12. The mother had said to my coworker, "You must arrange an apartment for Heidi [the patient]. We are all fed up, she must move out straight away." Quite peculiar expectations. After all we are a psychiatric institution, not a housing agency. 
Because they did not have so much face-to-face contact with the clients, they used impersonal clinical voices, and psychiatric discourse. They constructed typical narratives of themselves within the psychosis treatment process.

13.

\author{
With psychotic patients I have automatic patterns of thinking. Whenever \\ possible I don't question their experiences or thoughts - you have to do it so \\ often anyhow. In long run there is a risk that we don't dare to bring up vital \\ matters.
}

\title{
Discussion
}

The aim of this study was to characterize psychiatrists' inner dialogues concerning their agency in Need-Adapted teamwork. All the interviewees felt that they had made and acted upon relevant choices, but reported also instances they could have handled better. The interviewees utilized the interviews as a form of clinical supervision, and those who had an ongoing therapeutic relationship with the clients planned changes to the treatments. The diverse barriers to agency resulted partly from the dual-role dilemma (Robertson, 2008), with psychiatrists finding themselves to be servants of several masters. The strength of institutional forces seen in the study was also found in a study by Austin (2008): actions became agent-less, which was experienced as morally disturbing by the psychiatrists. According to Galeazzi, Mackinnon, and Curzi (2007), psychiatrists perceived conflicting demands of their social control function and the collaborative model they wished to follow. This was seen in the present study, in particular with regard to the inpatient setting. VuokilaOikkonen's (2002) study on acute inpatient care showed how difficult and important it was for authoritarian participants to give space for the expressions of clients and coworkers within common meetings.

Psychiatric discourse was used when speaking of clients: they were patients or relatives rather than human characters. This tendency was strengthened by the suppression of creativity in psychiatric hospitals. Psychiatrists with family therapeutic training - a proper training to meet the practical challenges of therapy meetings of NAA - had critical reflections on the tendency to focus on pathology or on a diagnosis such as schizophrenia. The involvement of patients' natural networks - particularly siblings and friends - increased the number of voices outside psychiatry.

The NAA tradition has features in common with the concept of shared decision making (SDM). A review of papers concerning SDM (Patel, 2008) found that patients' motivation to 
participate was often explained by their past negative experiences of, i.e. involuntary treatment, and that they generally have preferred greater participation than was offered. Patients emphasized the importance of trust in their service providers, which they avoided to offend viewing them as family members. The therapy meetings conducted within NAA, which are broader, psychotherapeutically-oriented multiprofessional family discussions, could provide an opportunity to respond to patients' needs for greater participation and, to process involuntary acts in such a way as to bring about better confidence in the professionals. Seale et al. (2006) reported findings that are consistent with the present study, e.g. emphasizing the benefits of knowing clients for a long time, expressing a human response, and facing up to the limitations of one's knowledge. However in our study though the psychiatrists working solely in an outpatient setting had a consultant role which emphasized the stance of medical psychiatry, as members of the case spesific team - one of the main principles of NAA - they had indirect agency concerning alternative treatment methods. The tradition of NAA can be seen also in the attitude towards medication: none of our interviewees concentrated particularly on strategies to enforce compliance with medication. Conversation analytic research (Quirk, 2012) has demonstrated the risk of losing the benefits of SDM through implementing the approach in such a way that the patient feels that he/she has little real influence. Our interviewees recognized clients' difficulties in expressing critical comments, and of professionals in responding to them; however, the reflective type of discussion used in CR-I was seen as opening up space for all parties to say and hear more.

Psychotic symptoms have been found to be a source of noticeable interactional tension and difficulty (McCabe, 2002). The anxiety associated with psychosis, the difficulties in tolerating uncertainty, and the formal responsibility laid upon psychiatrists impelled the interviewees - especially those with less experience - to choose actions that would calm the symptoms via medication and inpatient treatment. The opportunity of seeing psychosis as a form of agency and as an attempt to make sense of one's own experiences (Holma, 1999) was missed.

Psychiatrists who attended both in- and outpatient treatments were committed to the principles of NAA. Because they had diverse personal contacts with the clients, they were able - or as individuals, compelled - to have an emotionally rich inner dialogue concerning the whole context of the case. This extremely challenging arrangement required experience and psychotherapeutic training, and also personal conviction, including a readiness to be 
exposed to strong emotions. When these features were present the psychiatrist was able to experience the challenges of psychosis in a holistic manner, and to develop as a professional and as a person to adjust to the needs of the therapeutic relationship with the clients. It would appear that adherence to the principles of the open-dialogue approach (Seikkula, 2011) can contribute to the task. However, the risk of falling into a reductionist approach should be avoided: one needs to take into account local factors such as resources and professionals' personal realities. For good reasons, attention has been paid to the problem of unrealistic expectations for individual psychiatrists, and for psychiatric expertise as a whole (Austin, 2008; Rosen 2006). It appears that the concept of responsibility needs to be reframed in a more relational way (McNamee, 1999).

\section{Study limitations}

The psychiatrists' commitment to NAA varied. Nevertheless, because the composition of the CR-I resembled that of a therapy meeting - with the exception of the role of the interviewer we would argue that the challenges bound up with psychiatrists' inner dialogue in NAA are clearly visible in the study. The main researcher in the study was by no means a neutral observer and the future analysis will focus on the impact of the interviewer. The writers' commitment to NAA is also an eventual source of bias. Though some of the findings e.g. the tendency of inpatient setting to focus on symptoms, is obvious, we argue that the present study shows in a novel way the importance of the actual practice of choosing words which support recovery from psychosis.

\section{Conclusions}

According to the study psychiatrists have meaningful difficulties to follow the humanistic principles of NAA. Their opportunities e.g. to maintain psychotherapeutic attitude and to avoid the dominance of medical perspective could be improved by (family) therapeutic training. This would also support their abilities to meet the challenges to take part both in the inpatient and outpatient care of the same patient, which should me favored by the administration. The central challenge for psychiatrists is how to adapt their dialogical potentials to different contexts in which they meet clients (Quirk, 2012). Psychiatrists' creativity and their abilities to have agency in the language used with clients constitute underrated issues. It could be recommended that psychiatrists, as authoritarian participants, base their own speech not just to the words clients but also their coworkers in practice use and in the same time give words to their own experiences. Given this situation, the interview methods used in the present research could be utilized in practice. Using reflective positions 
in therapy meetings - which would include separating the turns of speaking and listening in the manner described by Andersen (1991) - could promote the openness of professionals, in such a way that they would not lose the respect of the clients, and open space for the clients to hear the professionals. The co-research interview method (CR-I) (Andersen, 1997) appears to be a suitable method for the purposes of clinical supervision: in every interview the presence of an experienced outsider brought new perspectives to the discussion, and helped the clients to evaluate the treatment process more openly. Overall, the clients' participation in the treatments, and also in the training and education of professionals, should be strengthened. The stimulated-recall interview method (STR-I) (Elliott, Slatick, \& Urman, 2001) can be used in professional training. It can substantially contribute to professionals' opportunities to have agency in their listening and in their use of language. It can help them to focus on patients' resources, and in this way open up a space in which patients can find words for their symptoms and for other frightening mute experiences (Seikkula, 2002).

\section{References}

Alanen, Y. O. (2009). Towards a more humanistic psychiatry: Development of need-adapted treatment of schizophrenia group psychoses. Psychosis: Psychological, Social and Integrative Approaches, 1(2), 156.

Andersen, T. (1997). Researching client-therapist relationships: A collaborative study for informing therapy. Journal of Systemic Therapies, 16(2), 125-133.

Andersen, T. (1991). The reflecting team: Dialogues and dialogues about the dialogues.

Austin, W. J. (2008). The balancing act: Psychiatrists' experience of moral distress. Medicine, Health Care \& Philosophy, 11(1), 89-97.

Borchers, P., Seikkula, J., \& Lehtinen, K. (2012). Psychiatrists' inner dialogues concerning workmates during need adapted treatment of psychosis. Psychosis, , 1-11. 
Burr, V. (2004). Social constructionism (2nd ed.). New York: Routledge.

Elliott, R., Slatick, E., \& Urman, M. (2001). Qualitative change process research on psychotherapy: Alternative strategies. In J. Frommer, \& D. L. Rennie (Eds.), Qualitative psychotherapy research: Methods and methodology. (pp. 69-111). Lengerich, Germany: Pabst Science Publishers.

Finnish Medical Society Duodecim / Current Care. (2008). Skitsofrenian käypä hoito. Helsinki: Suomen Psykiatriyhdistys. Retrieved from http://www.kaypahoito.fi/web/kh/suositukset/naytaartikkeli/tunnus/hoi35050;

Galeazzi, G. M., Mackinnon, A., \& Curci, P. (2007). Constraints perceived by psychiatrists working in community mental health services. development and pilot study of a novel instrument. Community Mental Health Journal., 43(6), 609-618.

Gleeson, J. F. M., \& McGorry, P. D. (Eds.). (2004). Psychological interventions in early psychosis: A treatment handbook. England: John Wiley \& Sons.

Goffman, E. (1961). Asylums: Essays on the social situations of mental patients and other inmates.

Holma, J. M. (1999). The search for a narrative - investigating acute psychosis and the needadapted treatment model from the narrative viewpoint. (Jyväskylä Studies in Education, Psychology and Social Research, 150 ed.). Jyväskylä: Univercity of Jyväskylä.

McCabe, R. (2002). Engagement of patients with psychosis in the consultation: Conversation analytic study. BMJ, 325(7373), 1148-51.

McNamee, S. [. (1999). Relational responsibility: Resources for sustainable dialogue.

Patel, S. R. (2008). Recent advances in shared decision making for mental health. Current Opinion in Psychiatry., 21(6), 606-612.

Quirk, A. (2012). How pressure is applied in shared decisions about antipsychotic medication: A conversation analytic study of psychiatric outpatient consultations. Sociology of Health \& Illness., 34(1), 95-113. 
Rakkolainen, V. (1991). Need-adapted treatment of schizophrenic processes: The essential role of family-centered therapy meetings. Contemporary Family Therapy: An International Journal., 13(6), 573-582.

Read, J., Mosher, L. R., \& Bentall, R. P. (Eds.). (2004). Models of madness - psychological, social and biological approaches to schizophrenia. . London: Routledge.

Rober, P., Seikkula, J., \& Laitila, A. (2010). Dialogical analysis of storytelling in the family therapeutic encounter. Human Systems: The Journal of Therapy, Consultation and Training, 21(1), 27-49.

Robertson, M. D. (2008). Many faces of the dual-role dilemma in psychiatric ethics. Australian and New Zealand Journal of Psychiatry., 42(3), 228-235.

Rosen,Alan a,b,c. (2006). The community psychiatrist of the future. Current Opinion in Psychiatry, 19(4), 380-388.

Seale, C. (2006). Sharing decisions in consultations involving anti-psychotic medication: A qualitative study of psychiatrists' experiences. Social Science \& Medicine, 62(11), 28612873.

Seikkula, J. (2002). Open dialogues with good and poor outcomes for psychotic crises: Examples from families with violence. Journal of Marital \& Family Therapy, 28(3), 263-274.

Seikkula, J. (2011). The comprehensive open-dialogue approach in western Lapland: II. longterm stability of acute psychosis outcomes in advanced community care. Psychosis: Psychological, Social and Integrative Approaches., 3(3), 192-204.

Topor, A. (2004). Vad hjälper? vägar till återhämtning från svåra psykiska problem. [What helps? Roads to recovery from severe mental illness.]. Stockholm: Natur och kultur.

Vuokila-Oikkonen, P. (2002). Akuutin psykiatrisen osastohoidon yhteistyöneuvottelun keskustelussa rakentuvat kertomukset. [Narratives unfolding in cooperative team meetings in acute psychiatric care] In Finnish with English summary. Department of 
Nursing Science and Health Administration; Department of Psychiatry, Oulu: University of Oulu.

Wortham, S. (2001). Narratives in action: A strategy for research and analysis; narratives in action: A strategy for research and analysis. 
THE NEED ADAPTED APPROACH IN PSYCHOSIS: THE IMPACT OF PSYCHOSIS ON THE TREATMENT, AND PROFESSIONALS

by

Pekka Borchers, Jaakko Seikkula, \& Tom Erik Arnkil, 2014

Ethical Human Psychology and Psychiatry, 16, 5-19.

Reproduced with kind permission by Springer. 


\title{
The Need-Adapted Approach in psychosis: the impact of psychosis on the treatment, the psychiatrists, and other professionals
}

\begin{abstract}
Psychosis is a challenging phenomenon for professionals. In the Need-Adapted Approach (NAA), therapy meetings constitute a deliberate effort to meet the challenges by bringing all the main parties together within a common discussion. The aims of this study are to analyze and evaluate psychiatrists' experiences of the treatment processes in psychosis. A qualitative multiple case study approach has been used. Between August 2007 and January 2009 coresearch interviews (CR-Is) and stimulated-recall interviews (STR-Is) with ten psychiatrists from three different part of Finland were videoed and transcribed verbatim. The material was analyzed using qualitative content analysis. The difficult emotions of the professionals and the critical views expressed had a prominent role. It was almost impossible to proceed with the treatment until the memories of coercive acts had been addressed. There were fewer harmful effects in outpatient than in inpatient care. If the client-centered principles of NAA were not followed, the CR-Is functioned primarily as critical evaluations of the treatment processes. The STR-Is helped the psychiatrists to find words for difficult experiences. For the sake of both practice and research, the experiences of staff in the treatment of psychosis should be taken into account. For better prediction of failure, routine measures to obtain feedback could be included in NAA.
\end{abstract}

Keywords:

psychosis; need-adapted treatment; psychiatrists' experiences; qualitative study

\section{Introduction}

Psychotic crises are distressing to patients and to their social network. They also constitute a challenge to professionals, not least to psychiatrists. The Need-Adapted Approach (NAA) (Alanen, 2009) incorporates an effort to bring the patient, her/his social network, and all relevant professionals together to meet the challenges that occur. In NAA the psychiatrist 
works as part of a team, and aspects of treatment are discussed and decided on together with patients, family members, and staff during therapy meetings (Rakkolainen, 1991). The meetings are guided by a psychotherapeutic attitude to find a common understanding of what has happened, and an evaluation of the real and changing needs of the patients and the family. Concrete treatment plans are drawn up and continuously revised within therapy meetings. The purpose is to work with the experiences of the clients, and to avoid the dominance of a medical perspective which could result in unnecessary treatments.

For several years, two of the writers have worked in psychosis teams as familytherapy professionals (the first author having trained as a psychiatrist, and the second author as a clinical psychologist). While following NAA procedures, we have observed many challenges associated with specific features of the psychosis phenomenon. Professionals find certain aspects of psychosis confusing and even threatening. They have to deal with the patient's loss of a sense of reality, incoherent psychological boundaries separating the self from others, gaps and shifts in associations, and the substitution of an organized and realistic logic by a more archaic logic of dreams - all this together with a weakening of impulse control because of delusions, hallucinations, and affective disorders (Alanen, 1997) This often leads to difficulties in treatment collaboration. Frequently, the professionals feel obliged to get the patients to admit their illness and to take medication to control their psychotic symptoms. The patients - who arrive upset, suspicious, and frightened in the first place - are left alone with their frightening experiences or even exposed to trauma, in the case of involuntary treatment.

Democratic societies deal with psychosis very differently from most other health problems. Though there are differences in Europe in both legislation and clinical practices regarding the compulsory treatment of psychotic patients (Jacobsen, 2012), psychiatrists and other professionals have exceptional power and responsibility in the 
processes concerned. All in all, it can be difficult to integrate the humanistic stance of NAA which is not based on interview manuals but on a more or less open dialogue between the participants at therapy meetings - with the institutional and scientific perspectives of medical psychiatry.

The ongoing research project - of which the present study forms part - is concerned with the inner dialogues of psychiatrists in the treatment process of psychosis, a process involving cooperation with the patient, her/his social network, and other professionals. The entire process of the research has been described in detail in two previous articles (*reference not mentioned because of the blind refereeing process). The NAA tradition is founded not on the immediate control of psychotic symptoms, but rather on the emergence of a dialogue between the patients and other participants in therapy meetings. Many of the universal issues arising in all relational practices (for example, the toleration of uncertainty) are exceptionally visible and tangible in NAA, given that the aim is to avoid means of control that would hinder dialogue. With this as background, the present study sought to analyze the experiences of professionals as revealed in interviews, addressing the following research questions:

(1) What psychosis-related issues were dealt with in the interviews? (2) What was the impact of these issues on the professionals and on the treatment processes?

\section{Need-Adapted approach, experiences of psychosis, and the therapeutic}

\section{relationship}

NAA has its roots mainly in Finland (Alanen, 1997), and partly in Sweden (Cullberg, Levander, Holmqvist, Mattsson, \& Wieselgren, 2002; Piippo \& Aaltonen, 2004; Piippo, 2008). However Gromer (2012) from United States have conducted a narrative review of seven studies of NAA concluding that outcomes were equivalent or superior to those 
obtained in standard care. All in all, there is ample research indicating that NAA is a useful approach (Aaltonen, Seikkula, \& Lehtinen, 2011; Haarakangas, 1997; Holma, 1999; IsoKoivisto, 2004; Keränen, 1992; Lehtinen, 1993; Seikkula, 1991 \&2011), but that it requires professionals to face the severe challenges mentioned above. The studies in question have addressed the impact of psychosis on the treatment provided; nevertheless, the experiences of professionals using NAA have been given more explicit attention only in a qualitative analysis linked to Acute Psychosis - Integrated Treatment Project (Aaltonen, Koffert, Ahonen, \& Lehtinen, 2000), which is the most resent Finnish national research and development project involving NAA.

There is a mutual dependence between the impact of psychosis on treatment processes, the human experiences of clients and professionals, and institutional factors within psychiatry. Some studies have been carried out on patients' experiences and understanding of psychosis (Geekie \& Read, 2009) and those of carers (Stern, Doolan, Staples, Szmukler, \& Eisler, 1999), but the literature has mainly ignored the embodied human responses of professionals. With a few exceptions (Engqvist, 2009; Hardcastle, Kennard, Grandison, \& Fagin, 2007), the professional perspective on psychosis has been presented via scientific theories of psychosis, or at most, the moral distress bound up with the psychiatrist's dual-role dilemma (Austin, 2008; Robertson, 2008). The therapeutic relationships between psychiatric staff and people with a diagnosis of psychosis appear to constitute a predictor of outcome (McCabe, 2004; Priebe, 2011). These relationships depend partially on personal features of the staff, for example, their attachment styles (Berry et al., 2008), and they have an impact on the work welfare of the staff members concerned (Dennis, 2007).

According to the phenomenological approach of Fuchs and de Jaegher (2009) which is based largely on the evidence of the role of social interaction in the development of mirror neurons in early childhood - social understanding is a process in which the lived 
bodies of the participants form a common incorporality. Because psychotic experiences are obscure and contradictory, and often even impossible to verbalize, the professionals as embodied agents are bound to be confused in their attempts to interact and align themselves with the patient. In NAA the aim from the very beginning is to constitute a boundary system in which the subjects and objects meshed with each other and to begin coevolution between the clients and the professionals (Seikkula, 1991).

\section{Research process and methods}

A qualitative multiple case study approach was chosen and the regional ethics committees gave the study positive statements. For therapeutic grounds the researcher mainly informed the different centers of the possibility to take part in the study and the staff, who themselves were willing to take part, chose the patients for the interviews. The first eight treatment process available was taken in the research. The interviews were conducted between August 2007 and January 2009. All interviewees were asked for their informed consent. The patients in the study had been treated for schizophrenic psychosis (diagnosis F20-29 according to the Finnish version of the International Statistical Classification of Diseases and Related Health Problems, ICD-10) for a maximum of two years. The ten psychiatrists from three different geographical locations of Finland included in the study were first interviewed together with the patient, family members, and coworkers, using the co-research interview method (CR-I) (Andersen, 1997). In CR-I, first the professionals and then the clients are asked to evaluate the treatment process, with the other parties listening in each case. The CR-I ends in an open discussion. Thereafter, the psychiatrists were interviewed about their thoughts, emotions, and experiences, using segments of videotapes from the earlier interviews, and applying a stimulated-recall method (STR-I) (Elliott, Slatick, \& Urman, 2001). In the present study, the STR-I was conducted individually, or in pairs in the case of two interviews in which 
psychiatrists from both in- and outpatient care were present. The interviewees and the interview process are described more detailed elsewhere (**reference not mentioned because of the blind refereeing process).

Each STR-I was transcribed verbatim. The researcher then divided the transcriptions into topical episodes (Linell, 1998). Using qualitative content analysis (Graneheim, 2004), closer examination was made of thematic episodes exhibiting some of the special features of psychosis, or some kind of change in the interview process; this could involve, for example, the psychiatrists starting to see the patients as healthier than before, or the emergence of new ideas concerning the treatment.

As the interviews were, quite literally, inter-views, involving a dialogical conversation on themes of mutual interest (Kvale, 1996), the voice of the interviewer formed part of the material for analysis. A subsequent article will address the changes in the interview process, and also the voice of the interviewer.

All significant decisions made during the entire research process were discussed at least four times per year during group meetings supervised by the second author. For this particular part study ATLAS.ti 6 software was used. The conceptualization of Graneheim and Lundman (2004) was found appropriate for the analysis applied in the present study. Thus, the manifest content refers to what is visible and obvious (what is actually said), while the latent content refers to the relationship aspect, and involves an interpretation of what is said. The final categorization was based on these concepts. Adjustments involved segments of the "latent data" being omitted from the category of manifest content, or being replaced with a more suitable category of latent content. The final assessment of trustworthiness was conducted via a discussion between the first and third author (a person who came to the study from outside psychiatry and who had not previously been involved in the study). The paper was rewritten following discussion of three questions, namely: Are the analysis and the 
results described plausibly? Would it be possible to construct a similar study following the steps outlined in the text? Is the narrative in the manuscript comprehensible?

\section{Results}

There were altogether 139 thematic episodes. Eighty-one of these involved psychosis, while in 85 it was possible to identify some kind of clinically meaningful change within the interviews. Seventy-one ( $84 \%$ ) of these changes concerned the discussion of the treatment of psychosis. We shall illustrate the results within partially overlapping categories, mainly following the conceptualization of Graneheim and Lundman (2004).

The first seven categories (the beginning of the treatment; psychotic symptoms; neuroleptic medication; involuntary acts; the setting of the treatment; the diagnosis; the family) are concerned with the manifest content of the interviews. Unless otherwise mentioned they embody what the psychiatrists in the interviews actually said. The last category (ethical issues) embodies the latent content. Unless otherwise stated, it refers to the researcher's interpretation of the meaning of the text. We shall address each of these categories by first setting out our understanding of the label used: thereafter we shall present our findings and provide a brief summing-up (in italics). We here use the word client to refer to the patients and also their family members, and the word professional to indicate all employees in psychiatry, whether interviewed or spoken about.

\section{The beginning of the treatment}

There are many challenges in the initial treatment of psychosis. The symptoms can make the therapeutic interaction difficult and arouse anxiety. In conjunction with the inflexibility of medical institutions and the attitudes and legal norms of society, emotional pressures often 
lead to overly simplistic treatment strategies that take no account of the experiences of the clients.

In this study, too, the start of treatment was observed to be of the utmost importance. There were difficulties in all cases, and only one case in which these difficulties had no impact on the rest of the treatment process. In six cases the initial difficulties resulted in hospital care, making the success of the treatment more problematic - particularly so in the case of the three patients undergoing involuntary treatment. If the clients felt mistreated at the start, the professionals were thereafter obliged to make great efforts to help the patients overcome their resentments and frustrations. In two different STR-Is the psychiatrists mentioned the risk of the staff becoming too cautious. In trying not to hurt the clients' feelings the professionals avoided issues which were relevant to the disorder and to recovery from it, for example the possibility of grief concerning the disorder.

The difficulties at the beginning of the treatment were more connected to hospital care; they made it difficult to focus on issues which might form the background of the psychotic crisis in the first place. Some psychiatrists noticed the extent to which they had been too cautious.

\section{Psychotic symptoms}

The dominant biomedical approach in psychiatry concentrates on symptoms, and this is especially the case in psychosis. Since psychiatrists have a social role in the process of involuntary commitment, this actually compels them to focus on symptoms such as a lack of a sense of reality.

Especially the professionals in the hospitals were indeed especially likely to concentrate on symptoms. There was thus a risk of misinterpreting ironic remarks made by patients, viewing such speech as psychotic, and not noticing the resources the remarks might 
illustrate. The patients had to exhibit exceptionally good mental health and competence if they were to convince the professionals of their capabilities. Some psychiatrists avoided questioning their patients' understanding as far as possible, feeling that the patients were, in any case, frequently being forced to face distressing confrontations. Psychotic speech and behavior aroused confusion among professionals, and feelings of threat. However, the professionals' experiences of threat showed wide variation with regard to a given patient's symptoms and behavior. Because of the legal responsibilities involved, it was extremely hard for inexperienced psychiatrists to tolerate uncertainty. The professionals tried to understand what had happened to the patient before the symptoms started, for example to think of possible stressors; however, discussion of the meaning of the psychotic symptoms, or of their basis in reality, occurred mainly with regard to two particularly acute cases, which were treated solely in an outpatient setting. The existence of negative symptoms, including a lack of initiative, was an important theme in one interview. In this instance the interview became a kind of meeting to formulate a treatment plan focusing on concrete behavioral ideas for future care. Because the patients in the CR-Is were present on a more equal footing and were able to talk about matters that were important to them, they were seen as healthier and as having more agency than during the actual treatment.

In the inpatient setting in particular, there was a risk of interpreting patients' speech and behavior as psychotic even when this was not the case. It appeared that some of the psychiatrists were attempting to protect patients from unpleasant confrontations.

\section{Neuroleptic medication}

According to the dominant biomedical approach of current psychiatry, antipsychotic medication constitutes a self-evident treatment for psychosis, and most often patients are either persuaded or forced to take drugs for the condition. 
Antipsychotic medication was used in all the cases in our study. It emerged that there was often too little discussion of medication during the treatment: thus, not merely the patients but also family members would have wished to have more information more rapidly. Because the psychiatrists were so used to the common side effects of the neuroleptics administered, it seldom crossed their minds to broach the matter with the clients. Even among agents working on the same case, contradictory expectations were expressed - ranging from skepticism to excessive optimism - concerning the effects of antipsychotic medication. Mention was also made of the need for close attention on the part of psychiatrists regarding the appropriate medication and the dose.

Neuroleptic medication was most often seen as the self-evident treatment for psychotic symptoms, at least by someone who played an important role in the treatment process. The case-specific differences and experiences of clients were easily overlooked in everyday clinical work.

\section{Involuntary acts}

As mentioned above, psychosis is a very special case in health problems: psychotic symptoms can result in involuntary treatment, and may also have forensic consequences.

Three of the eight patients were treated on an involuntary basis. The experiences of different kinds of coercive measures were of major importance for the entire treatment process. In particular, the experiences of forensic psychiatry and of coercive measures in relation to child welfare were felt to be traumatic by the patients and family members. At the worst extreme, the incidents were so abnormal that neither the clients nor the professionals could integrate them within their previous life experiences: as one client described it, it was like living in a nightmare. There was an obvious tendency for the discussions to become locked in these bad experiences instead of addressing the underlying 
disorder. When the professionals and the institutional environment reminded the patients of painful memories, it was somewhat easier and more useful to have the therapy meetings at the client's home. The psychiatrists had greatly differing perspectives on the coercive measures in force. At one end of the spectrum the principle was presented that the same professionals should continue to treat the clients and give them the possibility to talk about their experiences. At the other end of the spectrum it was felt that the situation was, in fact, so threatening and frightening that it was impossible to continue the treatment with a specific patient. A further point arising was that adherence to the legal principles was not as precise as the psychiatrists had expected. In fact, this could also have advantages: if a patient was treated on a voluntary basis (even if it should have been done involuntarily by law), the situation could be more comfortable for the patient.

The coercive measures were experienced as traumatic by the patients and families, and sometimes also by the professionals. It was almost impossible to proceed in a cooperative manner until the painful memories of coercion had somehow been addressed.

\section{The setting of the treatment}

In Finland, as in most countries, it is felt that outpatient care should be the primary care setting for psychosis. However, for a variety of reasons, inpatient treatment is often required.

More harmful phenomena occurred within inpatient than outpatient care. It was common for significant disagreements to arise between the patient and the staff in the ward, and this in turn hindered confidence and cooperation in the future. On the other hand, the hospital was regarded as a better setting if the patient was seen as requiring a structured environment, or if it was simply not possible to offer intensive outpatient care. The presence of fellow patients in the wards was thought to have various effects. The presence of chronic patients could increase a sense of hopelessness. On the other hand, the coping strategies of a 
peer group (involving for example the naming of hallucinations as a strategy for coping with voices) occasionally provided concrete benefits. Though outpatient care was generally regarded as the primary setting, it often failed, despite serious attempts to make it work. The decision on inpatient treatment could result from many factors, including the mistakes of professionals, boundaries between organizations, the clients' lack of knowledge of treatment possibilities, the inability of outpatient clinics to offer immediate help, and family members' anxieties and beliefs. Regarding the outpatient setting, it was observed that the psychiatrists were occasionally too cautious in challenging patients' views, due to a fear that that the patients would abandon the treatment.

The generally recognized goal - that psychotic crises should be addressed in the outpatient setting - was found to be demanding for the professionals concerned, and also the institutions. However, even though the professionals experienced more problems in the inpatient setting, some patient did obtain benefit from being in the hospital. It also seemed that outpatient treatment could sometimes lead professionals in the direction of over-caution.

\section{The diagnosis}

The importance of having a descriptive diagnosis has been highlighted in psychiatry, even though a possibly stigmatizing diagnosis (as in, for example, schizophrenia) is by no means a neutral factor in recovery.

In fact, the diagnosis of schizophrenia was generally avoided; this was a deliberate policy, or resulted from a sense that the label was unhelpful. The psychiatrists tended rather to speak of psychosis. Even if family members might sometimes wish to use the term schizophrenia, the psychiatrists seemed to be uncomfortable about using the word. On the other hand, if the patient himself/herself spoke of the possibility of having schizophrenia, this was seen as forming an important and useful opening. Melancholy and sadness after an 
episode of acute psychosis was labeled by some psychiatrists as postpsychotic depression, while others spoke about grief of becoming sick. The diagnoses were seen as approximations. Regardless of different viewpoints on diagnostic categorization the psychiatrists tended to avoid the diagnosis of schizophrenia. This could be explained in terms of maintaining optimism.

\section{The family}

Psychosis is a crisis for the whole family. Thus, the well-being of the family, including communication between members, forms an important aspect in the patient's recovery.

The professionals tended to relate to family members as carers rather than as clients with their own personal needs. Nevertheless, most psychiatrists were very well aware of the difficulties and suffering of family members, and valued their attempts, accepting their limitations, and even defending them against a patient's disrespectful behavior. On the other hand some psychiatrists criticized family members, expecting them to be capable of giving more assistance in the treatment. Consideration was also given to the causal roles of family members in the patients' disorders. In their desire to ensure that a young patient would continue with outpatient care, professionals were too willing to accept the patient's reluctance to ask family members to take part in the treatment. If the patient had a child, this resulted in major challenges regarding cooperation with clients and between different authorities. The psychiatrists had to make considerable efforts if they were to convince the child welfare services that a psychotic parent, together with her/his social network, was capable of taking care of the child.

Family members were seen as resources for the treatment, rather than as clients with their own needs. Occasionally the psychiatrists felt that the family could and 
should have done more for the patient. The concurrence of parenthood and psychosis constituted a particularly difficult and complicated dilemma.

\section{Ethical dilemmas}

Psychotic symptoms such as hallucinations and delusions challenge normality, overturn one's normal ways of sensing and thinking about one's environment, and give rise to a range of ethical dilemmas.

The need to engage in coercive measures constituted only one of the ethical dilemmas faced by interviewees. The psychiatrists had to struggle between the differing views of patients, family members, and other professionals and authorities (e.g. child welfare bodies). They also had to balance biomedical perspectives, institutional resources and responsibilities, attitudes in society, and their own human perspectives and needs. This resulted in a tendency to continue the treatment on a "just in case" basis, and not take sufficiently seriously the desire of a patient to end the treatment. There often appeared to be a gap between the structures or resources of the institutions and the needs of the clients. Some of the psychiatrists had negative and critical attitudes towards the clients. On the other hand, some of them had to find a stance which would allow them to confront the stigmatizing and manipulative attitudes of the treatment culture, or of co-workers. A small number of the professionals experienced elements of the psychosis treatment tradition as inhumane; indeed, one psychiatrist saw the treatment as belonging to another age entirely. Professionals who worked purely in the inpatient setting ran the risk of becoming accustomed to abnormal standards of interaction; this could lead them to emphasize control instead of listening and understanding. Some professionals found themselves battling between hope and cynicism.

\section{The everyday treatment of psychosis is characterized by crucial ethical} questions for psychiatrists and the psychiatric system. 


\section{Discussion}

If, at the start of treatment, the clients had no feeling of being respected and listened to by the staff, significant problems for the psychiatrist were likely to ensue. This was especially the case when the patient had painful memories of coercive measures. These had to be talked over before proceeding with the treatment. Even though the psychiatrists concerned were not personally responsible for previous shortcomings, they had a tendency to be over-cautious, and to avoid difficult issues. They might not wish to go deeply into background of the patient, including the psychotic crisis for which the patient had been admitted in the first place. Piippo (2008) observed that when clients experience mistrust it concerns the treatment system. One can suggest that professionals should consider such difficulties more in terms of problems affecting the therapeutic relationship, and try to modify their own responses accordingly. Thus they should be ready to speak openly about their own feelings (Seikkula, 1991). From this point of view, the clients' criticisms, and their eagerness to speak of their disappointments (which was observed in seven out of our eight interviews), actually provide psychiatrists with valuable information concerning how to relate to patients and continue cooperation with them. According to Piippo (2008) the ability of patients to criticize the personnel, and the ability of the personnel to tolerate such criticism, can increase patients' feelings of autonomy.

The psychiatrists experienced far more problems when in-patient treatment was involved. However, it often seemed almost impossible to avoid hospitalization. There are different perspectives on this issue, but overall we would here agree with Keränen (1992) that the crucial factor influencing the choice between outpatient and inpatient treatment is the reciprocal interaction between the clients and the team. From our interviews, it appeared that the staff in the hospitals ran a major risk of becoming accustomed to abnormal and even 
inhumane procedures. Occasionally the psychiatrists found it ethically very difficult to be part of the system. There seemed to be a tendency in psychiatric hospitals to see the patient as an illness, rather than as a multifaceted human being. This led to the hindering of learning through a wish to avoid risk. The ethical distress felt by the psychiatrists in our study was similar to professionals' first-person accounts of their experiences in the inpatient setting (Hardcastle et al., 2007). . If the clients and the staff were able to cope with the uncertainty connected to the treatment of acute psychosis on an outpatient basis, positive effects emerged: in addition to all parties being more satisfied, there was more discussion of what the psychosis actually signified. In the outpatient setting, it is easier to have conversations with symbolic meanings (Seikkula, 1991). This makes it possible for the clients to construct a meaningful understanding of the psychotic experiences, and it strengthens clients' feelings of agency (Holma, 1999). A comprehensible psychosis narrative has been found to be important for the recovery of patients (Geekie \& Read, 2009). Psychosis exhibits a prenarrative quality of life (Holma, 1999), and in addition, it can be seen as a kind of catalyst. If the basis of the treatment is not to get rid of the acute symptoms by medication or to simply define them as sign of an illness, and if the patient is seen as a competent participant in the conversation, the experience of psychosis can oblige parties to try to find some common understanding of what has happened. According to Karatza and Avdi (2011), psychotic family members run the risk of being positioned purely in terms of the psychiatric discourse employed; by contrast, therapeutic change is associated with the personal and reflexive voices of participants.

One factor which tended to prompt the interviewees to continue the treatment on a "just in case" basis was the psychiatrists' dual role dilemma (Robertson, 2008), i.e. the moral distress of balancing between different expectations (Austin, 2008). Such a perspective is problematic from the point of view of patients' agency, bearing in mind that the patient's own decision to quit or adjust medication should be seen as an act of taking agency (Iso- 
Koivisto, 2004); hence, suggestions to end or reduce the therapy meetings can be regarded as attempts to take more responsibility for the treatment relationship. Horizontal expertise and open dialogue for deritualization of the treatment is recommended (Aaltonen et al., 2000) if one is seeking to take all voices seriously and support the empowerment of clients. This does not require the total abandonment of the biomedical approach. According to Geekie and Read (2009), to the extent that they are active participants in the process, patients recovering from psychosis are able and willing to integrate multi-factorial contradictory accounts of psychotic experiences. Since the psychotic episode is an overwhelming phenomenon it is understandable that clients are eager - or even feel compelled - to use sophisticated thinking in order to make sense of the experience.

According to our study, strong emotions endangered the agency not just of the clients but also that of the professionals. Haarakangas (1997) found that NAA is challenging to inexperienced professionals in particular. Indeed, the emotions of professionals form both a challenge and an opportunity. One of the main aims of professionals working along NAA lines is to generate dialogue concerning themes that are difficult for the clients. The emotional responses of professionals are good starting-points for this purpose. Our results are in line with those obtained by Haarakangas (1997), indicating that the reflective discussions of professionals in the presence of the clients help the staff to discuss delicate issues respectfully and openly.

In NAA one of the main principles is often expressed as "minimal neuroleptics," referring to both the dose and the length of drug treatment. Antipsychotic medication is administered merely to support and assist psychosocial treatments and communication (Lehtinen, 1993). To guarantee that patient will only minimally lose her/his agency for iatrogenic reasons, the psychiatrist should be extremely active in discussing medication (Iso-Koivisto, 2004; Lehtinen, 1993). Nevertheless, our observations indicate that 
this tends not to occur in the real-world setting. The psychiatrists experienced guilt at not taking more initiatives to discuss medication with clients, within their sometimes hectic everyday practice.

The psychiatrists avoided to use of the diagnosis of schizophrenia, sometimes as a means to maintain hope. This practice is supported by research (Read \& Haslam, 2004; Read, 2004) which casts doubt on the usefulness and relevance of the concept of schizophrenia. Through interviews with patients, Iso-Koivisto (2004) found that there were major individual prognostic impacts for self-stigmatization when the diagnosis of schizophrenia was given, depending also on how the diagnosis was told.

Unlike some individually oriented psychotherapeutic approaches whose aim in the first place is to create dialogue with the patient (Lysaker, 2007), NAA takes a more a family-therapeutic approach, striving to generate dialogue between the patient, her/his social network, and the professionals concerned. With respect to patients' relatives, our findings are fairly similar to those of Piippo (2008). The family members tended to be seen as resources by the professionals. Nevertheless, the team occasionally paid more attention to the views of the relatives than those of the patient. According to our former study (***reference not mentioned because of the blind refereeing process) this could develop into a situation in which the patients actually became excluded, due to the critical attitudes of family members. The relatives could act in such a way as to lead the professionals to unite in a kind of usagainst-them manner, with the patient being left alone, between the parties.

In the study by Stern and his associates (1999) negative symptoms made it more difficult for the family members to construct a story that made sense. Our own results indicate that symptoms such as a lack of initiative led to a greater of indicative, concrete language (including efforts to try find concrete behavioral ideas for the treatment), in preference to conversations that would aim towards a more abstract understanding of the 
problem. Stern et al. (1999) also found that women had the primary role as carers. This is line with our observation that no male family members attended our interviews. Here we can identify an important clinical challenge, namely to include more voices of male family members in the therapeutic processes, and relieve the burden on female relatives.

Occasionally the professionals in our study experienced family members as critical and challenging. The issue is one of collaboration, and of not viewing family members merely as a number of discordant individuals. The overall need is to look for opportunities to integrate critical voices within a common understanding.

The difficult emotions of professionals and the critical voices of interviewees had a prominent role in our study. For a variety of reasons most of the treatment processes turned out to be unusually challenging. There was variation on the part of the professionals and the research center with regard to commitment to the principles of NAA. Often the clientcentered principles of NAA were not followed successfully, and drugs, in-patient treatment, and coercive measures were used to take control of the crisis. On those occasions CR-Is largely constituted a common critical evaluation of the treatment process. For their part, the STR-Is could be said to have had a positive function, in so far as they assisted the psychiatrists, together with the interviewer, to find words for uncomfortable and sensitive thoughts and emotions.

\section{Study limitations and strengths}

Unsurprisingly, simple generalizations are not possible based on our findings, which are based on small number of selected interviewees. Nonetheless our observations, and also other studies, show the relevance of findings concerning the impact of psychosis on professionals and on the treatment. Some of the results may well apply also to other severe mental disorders. On the other hand, psychosis is a particular phenomenon from the perspective of 
experience and communication - and also from the point of legal implications - and these aspects emerged strongly in our interviews. One of the strengths of the study is that exceptionally challenging cases were selected for our research. It should be noted that we did not set out to study the dialogues that occurred in the therapy meetings themselves.

Nevertheless, the main issues concerning psychosis and the arousal of emotions did emerge within the discussions, when the participants (persons who had been involved from the beginning) met in the CR-Is. Given that the first two authors are committed to the tradition of NAA, one can see here a possible source of bias. However, the third writer came from totally outside psychiatry, and had a major role in evaluating the trustworthiness of the study. We were also able to find other studies with similar results from outside the tradition of NAA. As mentioned above, the voice of the researcher exerted a clear influence on the course of the interviews. In a subsequent paper we shall focus on the impact of the interviewer on clinical relevant changes, which happened in the research process.

\section{Conclusions, implications for practice, and further research}

Psychotic reactions should be seen as attempts to make sense of one's experiences and to cope with experiences that are so difficult that it has not been possible to construct a rational spoken narrative about them (Seikkula, 2002). If we are to help the patients and their families to find ways of dealing with the situations, we need to apply vertical knowledge, based on professional expertise, and also horizontal knowledge, based on interactive work, and drawing on the resources of the participants in therapy meetings (Laitila, 2009). To generate more valid horizontal knowledge, which has relevance in the real world clinical practice, we also need to take into account the treatment setting and the experiences of the staff (Aaltonen et al., 2000) in research as well as in clinical practice. 
It has been found that positive effects can be obtained by modifying the perceptions of the staff concerning individual patients, and helping them to develop psychological formulations (Berry, 2009). In NAA the concept of a shared image guiding the treatment process (Aaltonen \& Räkköläinen, 1994) is particularly valuable for hospital teams, since keeping this concept in view helps staff to make choices that are more oriented to the clients' stories. In the original study by Aaltonen and Räkköläinen the therapeutic understanding of the patient was based on a conversation between the staff and a supervisor. In contrast, we would prefer to include the clients in these discussions, for example by using the CR-I method. In fact, both interview methods used in our study turned out to be useful in the treatment processes (of psychosis). STR-I can be used as a means to find words for experiences which remain implicit with participatory observation.

Psychotherapy research has demonstrated fairly convincingly that the therapy outcome has a particularly strong dependence on the therapeutic relationship (Lambert \& Barley, 2001; Lambert, 2005; Norcross, 2011). A variety of measures of both the alliance and the outcome have been developed to improve the success rate and predict failures (Lambert et al., 2002; Miller, 2005). In NAA the therapeutic relationship is emphasized. Concerning the treatment of psychosis, there is at least some evidence that the therapeutic relationship actually has a role as an independent predictor of treatment outcome (McCabe, 2004; Priebe et al., 2011). Promising efforts have been made to develop measures that would help professionals to meet the needs of individual patients diagnosed with psychosis (Priebe et al., 2007; van Os et al., 2004). In order to secure the ability of clients to give honest feedback, and to avoid treatment failures, it might be worth investigating measures that could be used routinely in therapy meetings. In so doing, it will also be possible to give a better evaluation of the therapeutic processes of NAA. 


\section{References}

Aaltonen, J., Koffert, T., Ahonen, J., \& Lehtinen, V. (2000). Skitsofrenian tarpeenmukainen hoito on ryhmätyötä : Raportti akuutin psykoosin integroitu hoito -projektin tuottamista hoitoperiaatteista [Need-spesific treatment of schizophrenia is teamwork. A raport on the treatment principles yielded by the project on the integrated treatment of acute psychosis.] In Finnish with English summary. Helsinki : National Research and Development Centre for Welfare and Health (STAKES).

Aaltonen, J., \& Räkköläinen, V. (1994). The shared image guiding the treatment process - A precondition for integration of the treatment of schizophrenia. British Journal of Psychiatry, 164(suppl. 23), 97-102.

Aaltonen, J., Seikkula, J., \& Lehtinen, K. (2011). The comprehensive open-dialogue approach in western lapland: I. the incidence of non-affective psychosis and prodromal states. Psychosis, 3(3), 179-191.

Alanen, Y. O. (1997). Schizophrenia: Its origins and need-adapted treatment. (S. Leinonen Trans.). London: Karnac Books.

Alanen, Y. O. (2009). Towards a more humanistic psychiatry: Development of need-adapted treatment of schizophrenia group psychoses. Psychosis, 1(2), 156-166.

Andersen, T. (1997). Researching client-therapist relationships: A collaborative study for informing therapy. Journal of Systemic Therapies, 16(2), 125-133.

Austin, W. J., Kagan, L., Rankel, M. \& Bergum, V. (2008). The balancing act: Psychiatrists' experience of moral distress. Medicine, Health Care \& Philosophy, 11(1), 89-97.

Berry, K., Shah, R., Cook, A., Greater, E., Barrowclough, C. \& Wearden, A. (2008). Staff attachment styles: A pilot study investigating the influence of adult attachment styles on 
staff psychological mindedness and therapeutic relationships. Journal of Clinical Psychology, 64(3), 355-263.

Berry, K., Barrowclough, C. \& Wearden, A. (2009). A pilot study investigating the use of psychological formulations to modify psychiatric staff perceptions of service users with psychosis. Behavioural and Cognitive Psychotherapy, 37(1), 39-48.

Borchers, P., Seikkula, J., \& Lehtinen, K. (2013a). Psychiatrists' inner dialogues concerning workmates during need adapted treatment of psychosis. Psychosis,5(1), 60-70.

Borchers, P., Seikkula, J., \& Lehtinen, K. (2013b). Psychosis, need adapted treatment, and psychiatrists' agency. Psychosis, http://dx.doi.org/10.1080/17522439.2012.755218.

Cullberg, J., Levander, S., Holmqvist, R., Mattsson, M., \& Wieselgren, I. (2002). One-year outcome in first episode psychosis patients in the swedish parachute project. Acta Psychiatrica Scandinavica, 106(4), 276-285.

Dennis, A. M. \& Leach, C. (2007). Expressed emotion and burnout: The experience of staff caring for men with learning disability and psychosis in a medium secure setting. $J$ Psychiatr Ment Health Nurs, 14(3), 267-276.

Elliott, R., Slatick, E., \& Urman, M. (2001). Qualitative change process research on psychotherapy: Alternative strategies. In J. Frommer, \& D. L. Rennie (Eds.), Qualitative psychotherapy research: Methods and methodology. (pp. 69-111). Lengerich: Pabst Science Publishers.

Engqvist, I. \& Nilsson, K. (2009). Psychiatric nurses' descriptions of women with postpartum psychosis and nurses' responses--an exploratory study in Sweden. Issues in Mental Health Nursing, 30(1), 23-30.

Fuchs, T. \& de Jaegher, H. (2009). Enactive intersubjectivity: Participatory sense-making and mutual incorporation. Phenomenology and the Cognitive Sciences, 8(4), 465-486. 
Geekie, J. \& Read. J. (2009). Making sense of madness: contesting the meaning of schizophrenia. London: Routledge.

Graneheim U.H. \& Lundman, B. (2004). Qualitative content analysis in nursing research: Concepts, procedures and measures to achieve trustworthiness. Nurse Education Today, 24(2), 105-112.

Gromer, J. (2012). Need-adapted and open-dialogue treatments: Empirically supported psychosocial interventions for schizophrenia and other psychotic disorders. Ethical Human Psychology and Psychiatry: An International Journal of Critical Inquiry, 14(3), $162-177$.

Haarakangas, K. (1997). Hoitokokouksen äänet: Dialoginen analyysi perhekeskeisen psykiatrisen hoitoprosessin hoitokokouskeskusteluista työryhmän toiminnan näkökulmasta [The voices in treatment meeting. A dialogical analysis of the treatment meeting conversation in family-centered process in regard to the team activity.] In Finnish with English abstract. Jyväskylä: Jyväskylän yliopisto.

Hardcastle, M., Kennard, D., Grandison, S., \& Fagin, L. (Eds.). (2007). Experiences of mental health in-patient care - narratives from service users, carers and professionals. London: Routledge.

Holma, J. M. (1999). The search for a narrative: Investigating acute psychosis and the needadapted treatment model from the narrative viewpoint. Jyväskylä: University of Jyväskylä.

Iso-Koivisto, E. (2004). "Pois sieltä, ylös, takaisin" - ensimmäinen psykoosi kokemuksena. ["Away from there, upwards, back again" - meaning given to the experience of first psychotic episode.] In Finnish with English abstract. Turku: Turun yliopisto.

Jacobsen, T. B. (2012). Involuntary treatment in europe: Different countries, different practices. Current Opinion in Psychiatry, 25(4), 307-310. 
Karatza, H. \& Avdi, E. (2011). Shifts in subjectivity during the therapy for psychosis. Psychology and Psychotherapy: Theory, Research and Practice, 84(2), 214-229.

Keränen, J. (1992). Avohoitoon ja sairaalahoitoon valikoituminen perhekeskeisessä psykiatrisessa hoitojärjestelmässä. [The Choice between Outpatient and Inpatient Treatment in a Family Centered Psychiatric Treatment System.] In Finnish with English abstract. Jyväskylä: Jyväskylän yliopisto.

Kvale, S. (1996). InterViews - an introduction to qualitative research interviewing. London: Sage Publications.

Laitila, A. (2009). The expertise question revisited: Horizontal and vertical expertise. Contemporary Family Therapy: An International Journal, 31(4), 239-250.

Lambert, M. J. \& Barley, D. (2001). Research summary on the therapeutic relationship and psychotherapy outcome. Psychotherapy, 38(4), 17-32.

Lambert, M. J., Whipple, J. L., Vermeersch, D. A., Smart, D. W, Hawkins, E. J., Nielsen, S. L. et al. (2002). Enhancing psychotherapy outcomes via providing feedback on client progress: A replication. Clinical Psychology \& Psychotherapy, 9(2), 91-103.

Lambert, M. J. (2005). Early response in psychotherapy: Further evidence for the importance of common factors rather than "placebo effects". Journal of Clinical Psychology., Electronic; 61(7), 855-869.

Lehtinen, K. (1993). Family therapy and schizophrenia in public mental health care. Turku: Turun yliopisto.

Linell, P. (1998). Approaching dialogue : Talk, interaction and contexts in dialogical perspectives. Amsterdam: John Benjamins Publishing.

Lysaker, P. H., Buck, K. \& Hammoud, K. (2007). Psychotherapy and schizophrenia: An analysis of requirements of individual psychotherapy with persons who experience 
manifestly barren or empty selves. Psychology and Psychotherapy: Theory, Research and Practice, 80(3), 377-387.

McCabe, R. \& Priebe, S. (2004). The therapeutic relationship in the treatment of severe mental illness: A review of methods and findings. International Journal of Social Psychiatry, 50(2), 115-128.

Miller, S. D., Duncan, B. L., Sorrell, R. \& Brown, G. S. (2005). The partners for change outcome management system. Journal of Clinical Psychology, 61(2), 199-208.

Norcross, J. C. \& Wampold, B. (2011). Evidence-based therapy relationships: Research conclusions and clinical practices. Psychotherapy, Electronic; 48(1), 98-102.

Piippo, J. (2008). Trust, autonomy and safety at integrated network- and family-oriented model for co-operation : A qualitative study University of Jyväskylä.

Piippo, J., \& Aaltonen, J. (2004). Mental health: Integrated network and family-oriented model for co-operation between mental health patients, adult mental health services and social services. Journal of Clinical Nursing, 13(7), 876-885.

Priebe, S., McCabe, R., Bullenkamp, J., Hansson, L., Lauber, C., Mertinez-Leal, R. et al. (2007). Structured patient-clinician communication and 1-year outcome in community mental healthcare: Cluster randomised controlled trial. The British Journal of Psychiatry, $191(5), 420-426$.

Priebe, S., Richardson, M., Cooney, M., Adedeji, O. \& McCabe, R. (2011). Does the therapeutic relationship predict outcomes of psychiatric treatment in patients with psychosis? A systematic review. Psychotherapy and Psychosomatics, 80(2), 70-77.

Räkkolainen, V., Lehtinen, K. \& Alanen, Y. O. (1991). Need-adapted treatment of schizophrenic processes: The essential role of family-centered therapy meetings. Contemporary Family Therapy: An International Journal., 13(6), 573-582. 
Read, J. (2004). Does 'schizophrenia' exist? Reliability and validity. In J. Read, L. R. Mosher \& R. P. Bentall (Eds.), Models of madness - psychological, social and biological aprroaches to schizophrenia. (pp. 43-56). London: Routledge.

Read, J., \& Haslam, N. (2004). Public opinion - Bad things happen and can drive you crazy. In J. Read, L. R. Mosher \& R. P. Bentall (Eds.), Models of madness - psychological, social and biological aprroaches to schizophrenia. (pp. 133-145). London: Routledge.

Robertson, M. D. \& Walter, G. (2008). Many faces of the dual-role dilemma in psychiatric ethics. Australian and New Zealand Journal of Psychiatry., 42(3), 228-235.

Seikkula, J. (2002). Open dialogues with good and poor outcomes for psychotic crises: Examples from families with violence. Journal of Marital \& Family Therapy, 28(3), 263-274.

Seikkula, J., Alakare, B. \& Aaltonen, J. (2011). The comprehensive open-dialogue approach in western lapland: II. long-term stability of acute psychosis outcomes in advanced community care. Psychosis: Psychological, Social and Integrative Approaches, 3(3), 192-204.

Seikkula, J. (1991). Perheen ja sairaalan rajasysteemi potilaan sosiaalisessa verkostossa. [The Family-Hospital Boundary System in Social Network.) In Finnish with English summary. Jyväskylä: Jyväskylän yliopisto.

Stern, S., Doolan, M., Staples, E., Szmukler, G. L., \& Eisler, I. (1999). Disruption and reconstruction: Narrative insights into the experience of family members caring for a relative diagnosed with serious mental illness. Family Process, 38(3), 355-368.

van Os, J., Altamura, A. C., Bobes, J., Gerlach, J., Hellewell, J. S. E., Kasper, S. et al. (2004). Evaluation of the two-way communication checklist as a clinical intervention. The British Journal of Psychiatry, 184(1), 79-83. 